Historic, Archive Document

Do not assume content reflects current scientific knowledge, policies, or practices. 



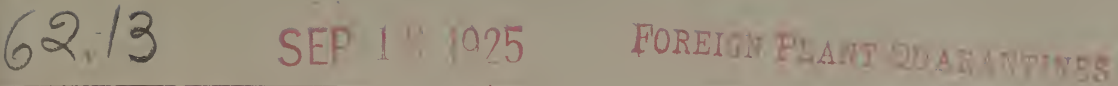

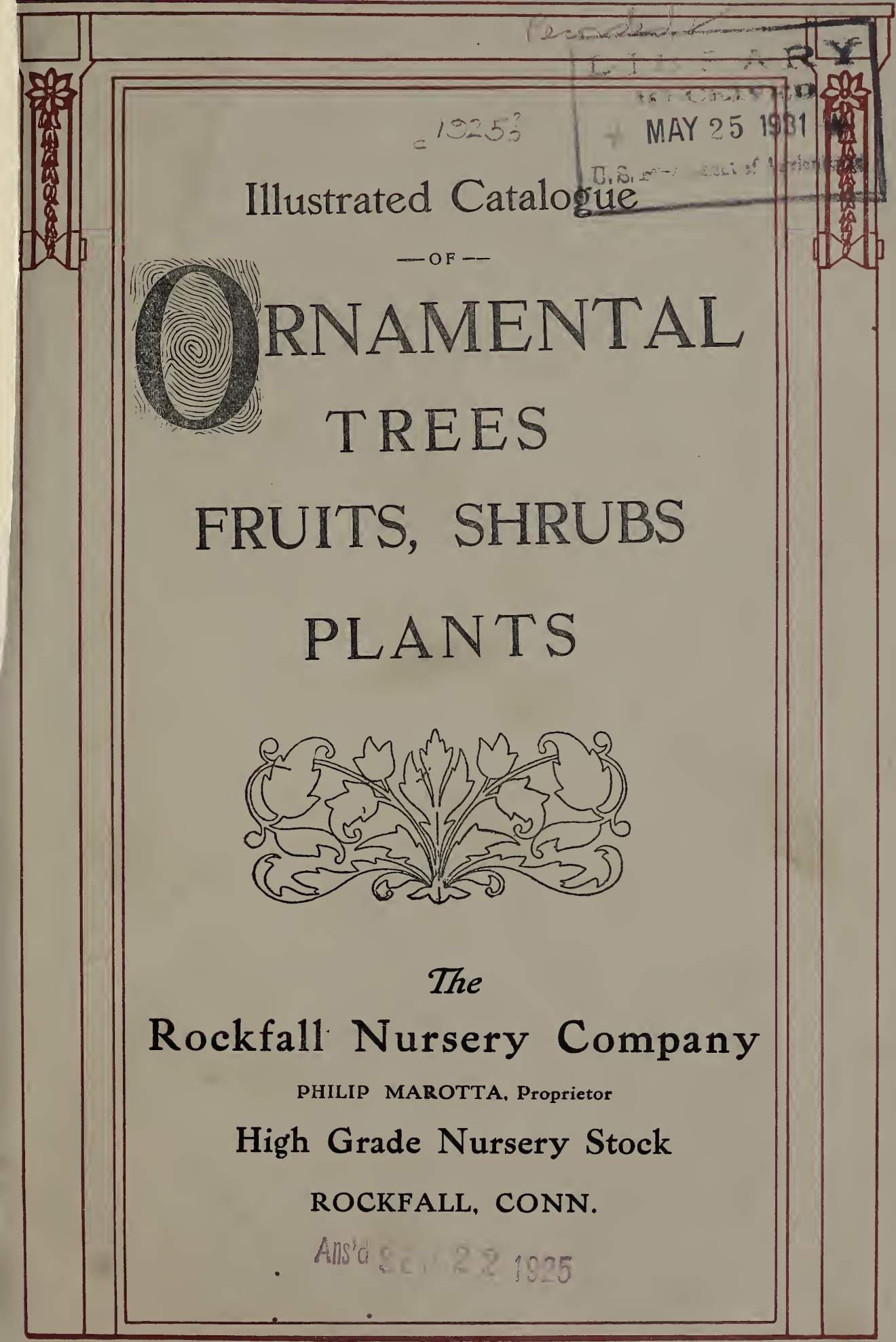




\section{DIRECTIONS FOR TRANSPLANTING}

\section{CARE OF STOCK, ETC.}

Care of Stock on Arrival-Upon arrival of box or package place it in a shed, barn or cellar away from sun, take off the cover and thoroughly wet down with water and allow it to stand twelve hours or over night before removing the stock. (Excepting Raspberry tips and Strawberry plants, which should be at once heeled in soil.) Then make ready a trench fourteen inches deep and as soon as stock is removed from the package heel it in this trench, giving the roots plenty of mellow soil, well pressed down with the feet. If soil is dry moisten it with water after heeling in; the trees are then ready for planting and should only be taken out as needed. If trees or plants are very dry or shriveled at once bury them, root, body and branch, in very moist soil, well pressed down, and leave them for four to six days, when they will be found as plump and fresh as when first dug. If frozen, no water should be applied, but they should at once be buried in earth until all frost is out, and they will nut be injured.

Soil-Should be high and well drained, either natural or artificial, by means of til- drainage. Low land continually saturated with water will not do. It must be deeply plowed and in perfect condition. Never plant fruit trees in sod. The land should be in as good condition as for a crop of wheat or potatoes. If poor, manure thoroughly or plow in heavy crops of clover beforehand. In the fall give the land a covering of rye, clover or veitches to be plowed under early the following spring. If any crops are grown in the young orchard let it always be a hoed crop and plant nothing nearer than four feet each side of the tree. If you want trees to grow well, be vigorous and strong, you must give them plenty of food and good cultivation until August 1st, when all cultivation should cease, to allow new wood to thoroughly ripen up before cold weather, which it will not do if kept growing by cultivation after that date.

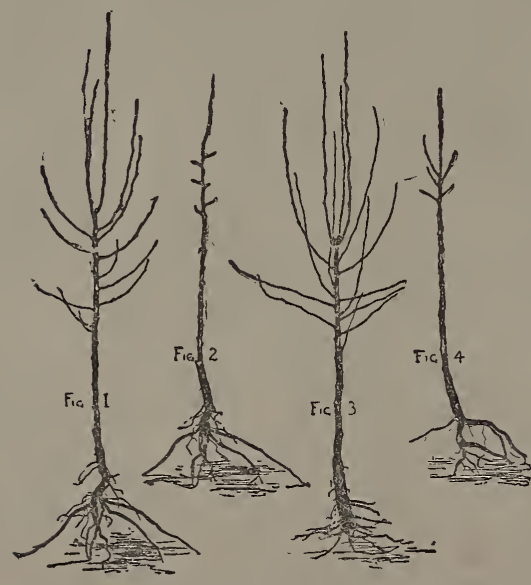

Figs. I and 3 show trees as they come frum the nursery, Figs. 2 and 4 show the same trees properly pruned back for planting.

Pruning-Is most important. In digging, more or less roots are lost of necessity. The top then must be cut back to even up for loss of roots. Leave only four or five branches and cut these back to four or five buds. Peaches are best trimmed to a whip or nearly so, and cut back to not more than 2 or 3 feet high. Remove all broken roots and branches and with a sharp knife cut the ends of the roots back to clean, healthy wood. This helps to start root growth. Fibers occupy the relation to the roots that leaves do to the branches, they die and are succeeded by another lot yearly, and are of no more value to the roots than dead leaves would be to the branches. Hence, you want plenty of large and small hard and clean roots, and the less fibers the better.

Planting-Make holes plenty large, so as not to crowd the roots. Use surface soil for filling in, and plant as firm as possible, pressing soil well down with the feet. See that roots are well spread out and soil firmly around themdon't hurry the job, do it well, and success is certain. After planting, each tree should be well mulched for two or three feet out with coarse manure. This prevents drying and is better than watering. The trees should not be long exposed to sun and air. Never put any manure in the holes with the roots, it causes decay.

Cultivation-We don't believe in allowing orchards in sod. You can't expect to get a paying crop without cultivation. Cultivate the orchard and keep it cultivated up to August 1st. The finest and most productive orchards we have ever seen are cultivated every ten days or two weeks during spring. The best fertilizer for a young orchard is a green crop plowed in every spring, or liberal manuring until trees are well grown and begin to fruit, after that, wood ashes or potash, with an occasional green crop plowed in, are better than barnyard manure and will supply all that is needed.

Young, Healthy Stock is much superior to old, or very large trees. Two or three year cld trees are more apt to live, are easier handled and can be trimmed or shaped to any desired form. and will outstrip older stock in growth. Practical fruit growers always plant young trees. 


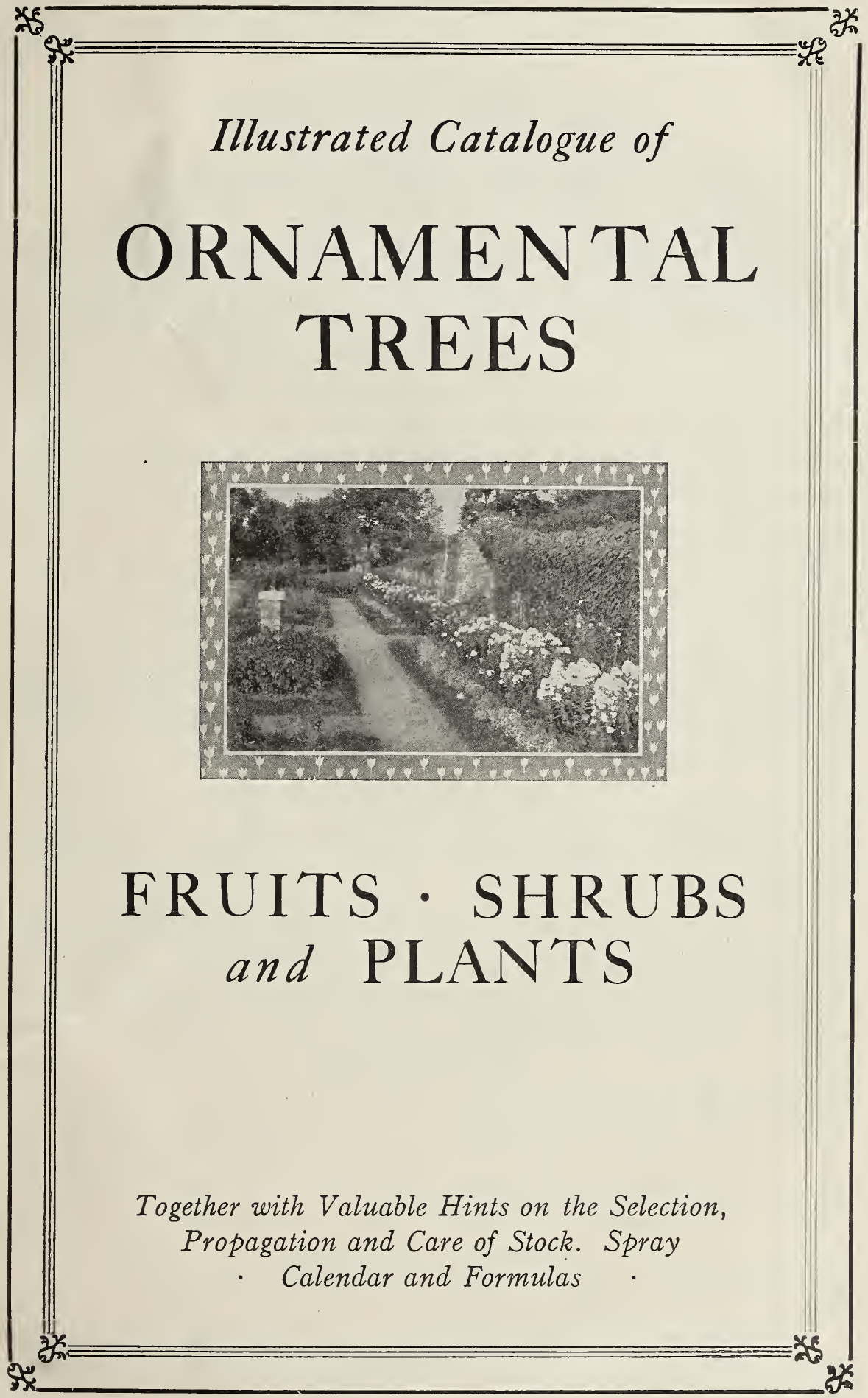




\section{INTRODUCTION}

T presenting this catalog to our customers we have the satisfaction of saying that we believe it to be the most complete in its list of what is desirable and obtainable in both fruits and ornamentals ever issued. With the assistance and advice of many of the leading growers and dealers thoughout an extended area in this latitude undesirable and unobtainable varieties have been omitted. All descriptions have been re-read and corrected where necessary to conform to the results of experience. Many new or hitherto uncataloged varieties have been added, and we feel sure that every reasonable requirement of our numerous patrons is here supplied.

We give special attention to the propagation of varieties that will come true to name, endeavoring to protect ourselves and our customers from error and imposition. We feel safe, therefore in offering our stock as being what it is represented to be. All packing and shipping is given personal supervision and, still further to protect our patrons against loss, only skilled and competent men are employed.

Our lands are well adapted to the growing of the varieties handled by us and this fact together with thorough cultivation and care makes for health, vigor, and maturity in all that we grow.

Before setting out any nursery stock, careful reading of pages 44 to 47 of this catalog will be of benefit. It is well to understand that nursery stock is perishable and demands careful attention after being received from the nursery. Persons who handle nursery stock intelligently seldom have any cause for complaint. We request you to read the directions on "Transplanting Trees and Shrubs." 


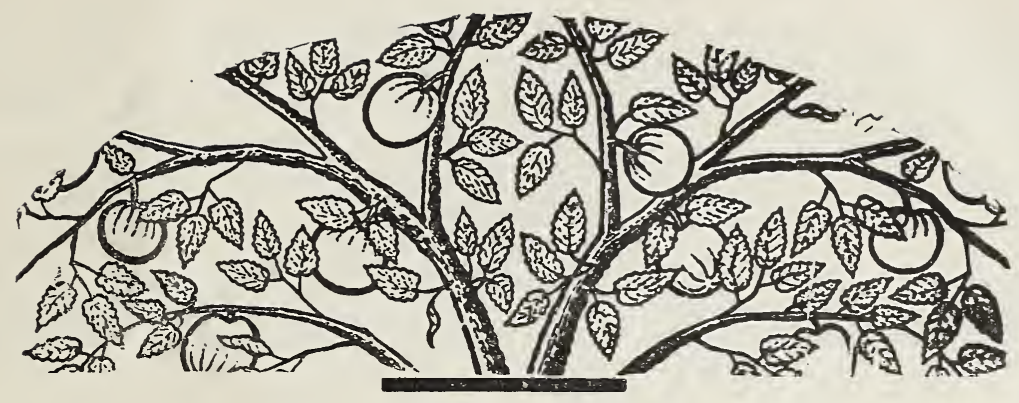

\section{Fruit Department}

\section{APPLES}

$\mathrm{T}$ HERE are but few parts of the United States where apples can not be grown. They are planted from 30 to 40 feet apart, depending on the tree growth made by the variety. In commercial orchards, the fewer varieties in one planting, the better. In home orchard plantings the assortment may be as large as desired. The apples described below are the best known sorts. Their value has been proved, and they will produce fine fruit in proper abundance.

\section{SUMMER VARIETIES}

Early Harvest-Medium size, straw color; tender, sub-acid. August.

Early Strawberry-Medium; roundish; Gnely striped and stained with deep red; flesh white, slightly tinged with red next the skin, tender, sub-acid, with an agreeable aroma. Tree a moderate, erect grower, and a good bearer. Middle to end of August.

Golden Sweet-Large; pale yellow; very sweet and good. August.
Red Astrachan-Large, deep crimson, juicy; rich, acid; August.

Red June-Medium; deep red; flesh tender, juicy, sub-acid flavor. Tree vigorous, an early and abundant bearer. August.

Sweet Bough-Large; pale yellow; tender and sweet. August to September.

Yellow Transparent-Very early; color, pale yellow. July and August.

\section{AUTUMN VARIETIES}

Alexander-Large, uniform; mild sub-acid. Tree upright, vigorous. September.

Duchess of Oldenburg-Medium size; yellow, streaked with red; juicy, with rich, sub-acid flavor. September.

Fall Pippin-Large, yellow; tender, juicy and rich. October.

Fameuse (Snow Apple)-Medium deep crimson. Very handsome; flesh snowy white, tender, melting, juicy. November.

Gravenstein-Large, striped; tender, juicy and high flavored. September.

Maiden's Blush-Medium size; pale yellow with beautiful red cheek. September and October.
McIntosh Red-Medium size; nearly covered with dark red; flesh white, fine, very tender, juicy. December.

Pound Sweet-Very large, round, greenish; sweet, rich and tender; excellent for baking. October and November.

Twenty Ounce-Very large; nearly round; yellow, striped with red; of fair quality; tree a vigorous, spreading grower, and a fine bearer. Excellent for baking. Very popular in the markets. October to January.

Wealthy-Free growth; medium; dark red; juicy, vinous, sub-acid; good; very hardy, Ripening October to January. 


\section{WINTER VARIETIES}

Baldwin-Large, bright red; juicy, crisp, sub-acid. One of the most popular winter apples. January to April.

Ben Davis-A leading commercial variety. Tree hardy, healthy, vigorous. Fruit large, handsomely colored, attractive. January to June.

Bismarck-Is making a wonderful record for hardiness and special earliness of fruiting. Two-year trees seldom fail to produce fruit. Tree is of stocky, short growth. Fruit golden yellow, splashed with red; flesh tender, pleasant, sub-acid. Will keep into March.

Black Ben Davis-Brilliant in color, attractive in appearance, deep red. Good keeper. Tree vigorous. January to April.

Delicious-Esteemed as a long keeper and valuable market fruit. Fruit large, roundish; skin greenish yellow, much shaded with light and dark red and sprinkled with brown dots; flesh yellowish, juicy, mild sub-acid. January to May.

Fallawater-Very large, globular; yellowish green, dull red cheek; juicy, crisp, pleasant sub-acid flavor. December.

Gano-A variety of the Ben Davis type. Fruit medium to large, light yellow in color and of good flesh and flavor. Season about the same as Ben Davis.

Golden Russet-Vigorous growth; medium; russet; crisp, juicy, mild sub-acid; hardy; very good; long keeper. Ripening November to April.

Grimes' Golden-Medium to large; cylindrical; golden yellow; flesh crisp, tender, juicy sprightly; very good to best. Tree hardy, vigorous, productive, bears early. January to April.

Hendrick Sweet (Sweet Winesap)-Fruit medium, round oblate; color red, splashed with deep crimson; flesh tender, juicy, very sweet and rich. November to May.

Hubbardston-Large, striped yellow and red; : tender, juicy. An excellent variety for commercial planting, being one of the most profitable varieties of its season. October.

Jonathan-Medium growth. Red and yellow; tender, juicy, and rich. Very productive. One of the best for table or market.

King (Tompkins County)-Largest size; oblate, yellowish grounded striped and covered with bright red; fragrant, spicy smelling; flesh very crisp, tender, rich, fine flavor, subacid. A superb apple. November to April.

Mammoth Black Twig-Greenish yellow covered with deep red, obscurely striped. Flesh yellow, very firm, juicy, good quality. A very late keeper. December to May.

Mann-Vigorous growth; medium to large; deep yellow; juicy, mild, pleasant, sub-acid: hardy. Ripening January to April.

Newton Pippin (Albemarle)-Medium to large, yellow; very firm, crisp, juicy, with a highly delicious sub-acid flavor. A very late keeper. November to June.

Northern Spy-Vigorous growth; large; striped red; tender, juicy, mild, sub-acid; very good; a fine dessert fruit. Ripening December to June.

Northwestern Greening-An attractive apple of green or yellowish color. Popular in the northern portion of the apple belt where hardy apple is desired. Fruit large to very large with mild sub-acid flavor.

Opalescent-An annual bearer of beautiful, high quality fruit. Size large; color light, shading to a very dark crimson, and susceptible to a very high polish; hence, its name. Ripening December to March.

Pewaukee-Vigorous growth; large; bright yellow with red; tender, juicy, sub-acid; good; very hardy. Ripening January to May.

Rambo-A fine flavored apple for home orchards. Does not keep well for commercial purposes. Fruit medium size.

November.
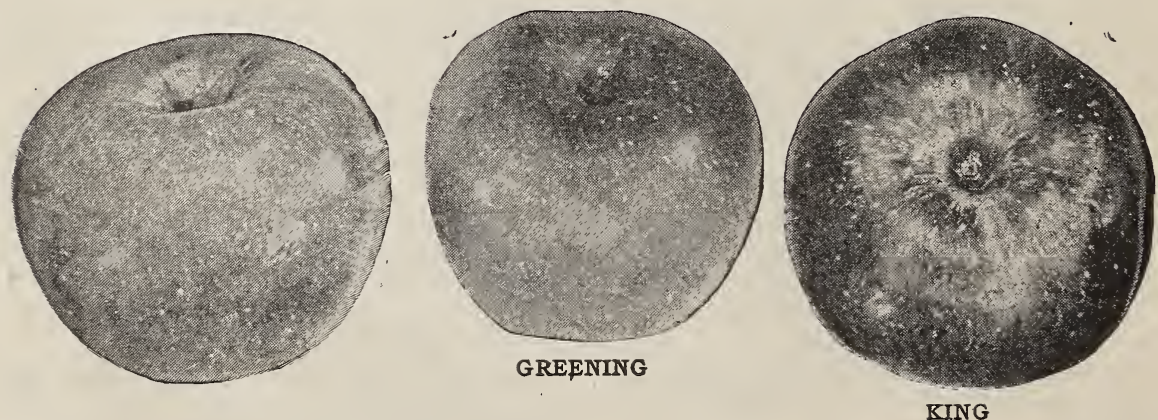


\section{OF N U R S E R Y S T O C K}

Rhode Island Greening-Large greenish yellow; tender, juicy and rich, with rather an acid flavor. December to April.

Rome Beauty-Large; yellow and bright red; flesh yellowish, tender, juicy, sub-acid; tree moderate grower, good bearer. December to March.

Roxbury Russet (Boston Russet) -Rather large; greenish-yellow, mostly covered with bright russet; a pleasant sub-acid flavor. January to June.

Seek-no-Further (Westfield)-Above medium; dull red, dotted with russet; flesh white, fine grained; rich flavor, excellent. December to February.

Smokehouse-Fruit is green, blushed; above medium in size. A very pleasantly flavored dessert apple of good quality. October to February.

Spitzenburg (Esopus)-Medium to large, deep red; flesh yellow, crisp, sub-acid, with a spicy and delicious flavor; a good bearer and a most popular variety. December to April.

Stark-Tree is thrifty, hardy, healthy, a reliable cropper and very productive. Fruit large and of a beautiful color and good flavor. January to May.

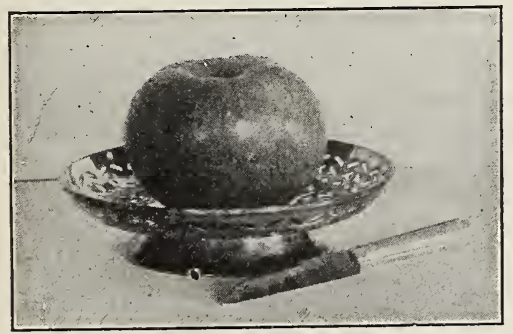

Stayman's Winesap-Large, bright red, striped; excellent quality. Flesh firm, tender, rich, juicy, mild sub-acid. A heavy bearer. Succeeds in a great variety of soils. February to April.

Sutton Beauty-Medium to large, roundish; handsome, waxen yellow, obscurely striped with fine crimson; flesh white, crisp, tender, juicy, sprightly sub-acid; quality fine; late keeper; tree productive. November to February.

Talman Sweet-Medium size; pale yellow, slightly tinged with red; firm, rich and sweet; excellent for cooking; tree vigorous, very hardy and productive. November to April.

Wagener-Medium to large; light yellow covered with deep red in the sun; firm, crisp, juicy, sub-acid; tree vigorous, upright, handome, very productive. December to May.

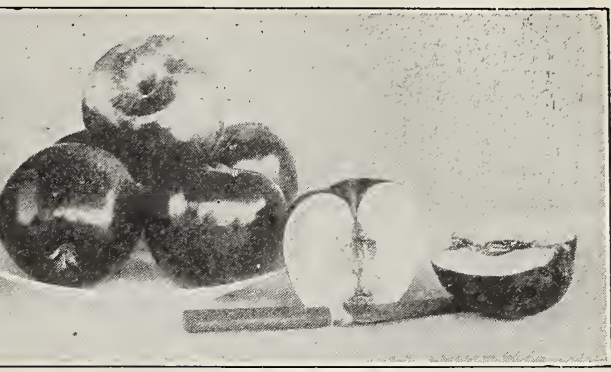

MCINTOSH RED

Winter Banana-The name is most appropriate, as it has a delightful banana perfume. Fruit keeps well till spring; the color is a striking red blush on a deep yellow ground. It is of large size and very showy in appearance.

Wolf River-A variety that has largely superseded Alexander in many localities. Tree a strong spreading grower, not an early bearer, productive in alternate years. Fruit is large, highly colored. September to December.

York Imperial-Medium; white shaded with crimson; flesh firm, crisp, juicy, pleasant, mild, sub-acid; tree vigorous, a good bearer. A popular Pennsylvania variety. November to February.

\section{CRAB APPLES}

Excelsior-Tree a strong grower, hardy and healthy. Fruit large for a crab apple and very attractive; flavor agreeable.

Hyslop-Almost as large as Early Strawberry Apple; deep crimson; very popular on account of its large size, beauty and hardiness. Vigorous. October to January.

Martha-Resembles the Transcendent, but larger; beautiful showy fruit and bears enormously. All things considered, we doubt if it has an equal among the crabs. Vigorous. September and October.

Transcendent-Skin yellow, striped with red; flesh crisp and juicy. An early and heavy bearer. One of the best known varieties. September and O'ctober.

\section{Whitney-}

Large, glossy green, splashed with carmine; flesh firm, juicy and flavor very pleasant; ripe latter part of August. Tree a great bearer and very hardy. August.

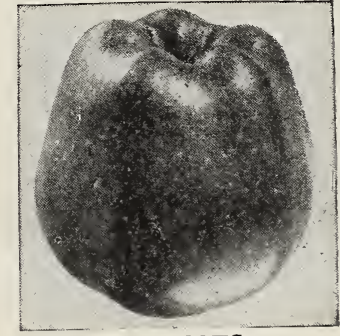

DELICIOUS 


\section{PLUMS}

The European plums were introduced from Europe in Colonial days. They are characterized by solid meaty flesh and free stone pits. The Japan plums, as a class have a distinctive flavor. They are almost as hardy as the Europeans and thrive over a wide range of territory. Plums offer us a great range of flavor, color, form and size. We have selected the following list of the most reliable and valuable kinds.

\section{EUROPEAN VARIETIES}

Bradshaw-Very large purplish red fruit of good quality. Very productive, and keep well. August.

Coe's Golden Drop-One of the largest and best of the yellow plums. Juicy, sweet, well flavored. September.

Fellemburg-Very large, purplish black. Best quality. September.

German Prune-Purple, juicy, rich, tne quality September.

Gueii-Very large, deep purple; flesh yellowish, sweet; hardy. September.

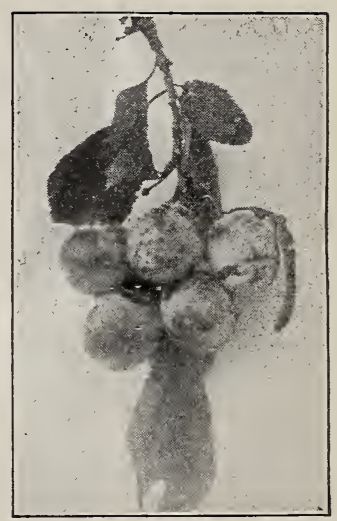

LOMBARD

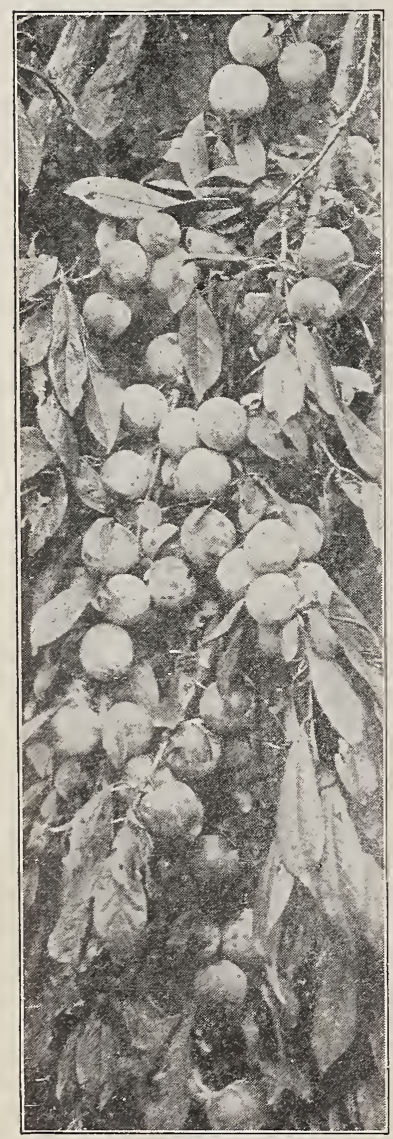

BRATCE OF BURBANK

Imperial Gage-Fruit large, oval, skin pale green, flesh juicy, sweet, rich and excellent. Vigorous. Middle of August.

Lombard (Bleecker's Scarlet)-Medium size; violet red; juicy, pleasant and good; adheres to the stone; productive. A valuable market variety; one of the most hardy and popular. Middle of August.

Moore's Arctic-Medium, dark purple, thin skin; fine flavor: a great bearer, extremely hardy. September.

Reine Claude-Large, nearly round; pale yellow, marked with red; juicy, melting and excellent; good bearer. Not liable to rot. First of September.

Shipper's Pride-Very large, dark purple, juicy, sweet, fine quality. Hardy and productive. September.

Shropshire Damson-A medium sized, dark purple variety: esteemed for preserving. Very productive. October.

Yellow Egg-Large, yellow; juicy and rich. Productive and vigorous. August.

\section{JAPAN VARIETIES}

Abundance-The tree comes into bearing remarkably young, and yields abundantly. The fruit is full medium size, color a rich, bright cherry red; flesh light yellow, juicy and tender. Vigorous. Last of July.

Burbank-A plum of deeper color and ripening later than the Abundance. The fruit is large, clear cherry red with a thin lilac bloom; flesh a deep yellow, very sweet, with a very agreeable flavor; begins to bear second year after trans planting. August.

Chabot or Yellow Japan-Very large; tapering; color bright red purple, on a yellow ground; very showy. Blooms two weeks later than Abundance, thus escaping the spring frosts and a most abundant bearer. Ripens a little later than Burbank.

October Purple-Reddish purple color. Flesh yellow and superb in quality. Ripens about middle of September.

Red June-An early ripening plum; medium to large, roundish, conical, purplish red, handsome; flesh yellow, quality good.

Satsuma-A fine, large Japanese plum. The flesh is solid, purplish crimson color from pit to skin, juicy, fine quality. Pit very small little larger than a cherry stone. September.

Wickson-The tree grows in vaseform, sturdy and upright. The stone is small and the flesh is of fine texture firm, sugary. and delicious. Ripens about September first. 


\section{OF N U R SER Y S TOCK}

\section{SWEET CHERRIES HEART AND BIGARREAU}

Bing-One of the most delicious sweet cherries. Fruit is large, black, and of very fine quality.

Black Tartarian-Very large, bright purplish black; half tender, juicy, very rich, excellent flavor; productive. Free. First or middle of July.

Dikeman-The latest ripening Sweet Cherry known; hence, after other sorts are gone, it commands highest price. Black, good size, and in texture reminds one of the cherries from the Pacific slope, being meaty and solid.

Gov. Wood-One of the best cherries; very large; light yellow marbled with red; juicy, rich and delicious. Tree healthy and a great bearer. Hangs well on the tree. Vigorous. Last of June.

Lambert-Largest size, firm, rich and juicy. purplish red, almost black when ripe.

Napoleon Bigarreau-Very large, pale yellow or red; very firm, juicy and sweet; very productive; one of the best. Vigorous. First of July.

Rockport Bigarreau-Large, amber and light red; half tender, sweet, rich and excellent. Tree vigorous, erect, beautiful and productive. Last of June and first of July.

Schmidt's Bigarreau-Remarkably hardy and productive. Fruit of the largest size; a deep mahogany color; flesh dark, tender, juicy with a fine rich flavor. July.

Windsor-Fruit large; liver colored; flesh remarkably firm, of fine quality. Tree hardy

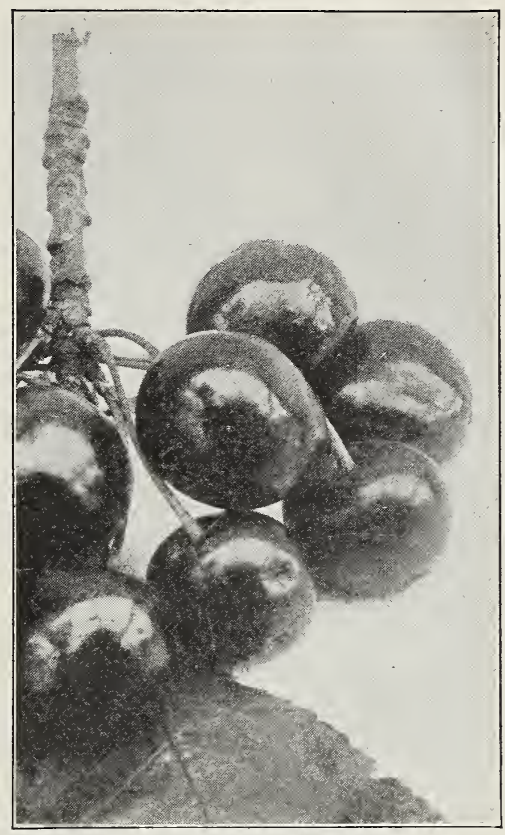

BLACK TARTARIAN

and prolific. Vigorous. Middle of July

Yellow Spanish-Large, pale yellow, with red cheek; firm, juicy and excellent; one of the best light colored cherries; productive. Free. Last of June.

\section{SOUR CHERRIES-DUKE AND MORELLO}

Baldwin-Fruit large, very dark transparent wine color; flavor slightly acid yet the sweetest and richest of the Morello type. Unexcelled in earliness, quality and productiveness.

Dyehouse-A very early and sure bearer; ripens a week before

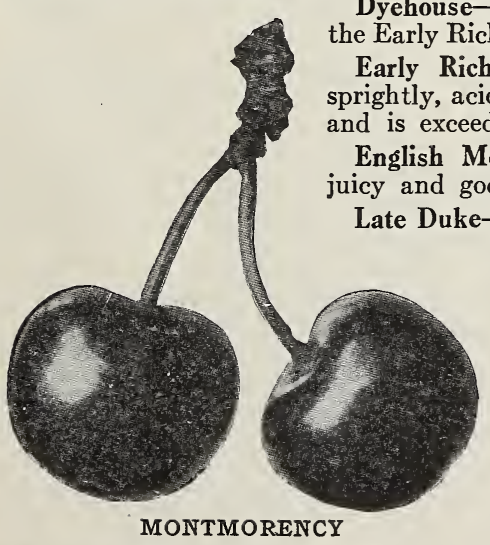

ichmond, of better quality and quite as productive. June.

Early Richmond-Medium size; dark red; melting, juicy, sprightly, acid flavor. This is unsurpassed for cooking purposes, is exceedingly productive. Free. June.

English Morello-Medium to large; blackish red; rich, acid, ; very productive. August.

Late Duke-Similar to May Duke, ripening 2 or 3 weeks later.

May Duke-Large, dark red, juicy and rich; an old excellent variety; productive. Middle of June.

Montmorency-A large red, acid cherry, larger than Early Richmond and fully ten days later. Very profitable. Last of June.

Olivet-A large, globular, very shining, deep red sort. The flesh is red; with a rose-colored juice, tender, rich and vinous, with a very sweet subacidulous flavor. Early June.

Ostheime-Medium size, very dark red highly flavored. Bears heavily. August.

Wragg-Very hardy. Fruit dark, juicy and rich. Tree a dwarf but vigorous grower and very prolific. Nearly like English Morello. 


\section{PEAR TREES}

Pears should be picked from the tree while "hard ripe," and allowed to mellow up in the house. If they become mellow on the tree they are practically worthless Keep them in a clean box till ripe. If you wish to retard the ripening, keep in a cool place. A cool dry cellar is best Standard pears thrivc on almost any moderately rich soil; well drained heavy loam is best.

\section{SUMMER VARIETIES}

Bartlett-Large size; buttery, very juicy and high flavored; very popular. September.

Clapp's Favorite-Large size; flesh fine grained, melting, rich and buttery; earlier than Bartlett. August.

Flemish Beauty-Large, juicy, melting, rich and fine; good bearer; hardy everywhere. September and October.

Koonce-Medium to large, handsome; yellow; flesh juicy, sweet, spicy, good. Ripens with the earliest. Tree a strong grower, hardy, and productive. August.

Osband Summer-Medium size; clear yellow with red cheek. Flesh melting and sweet. August.

Wilder-Small to medium; yellow, with red cheek; handsome; sweet, delicious. August.

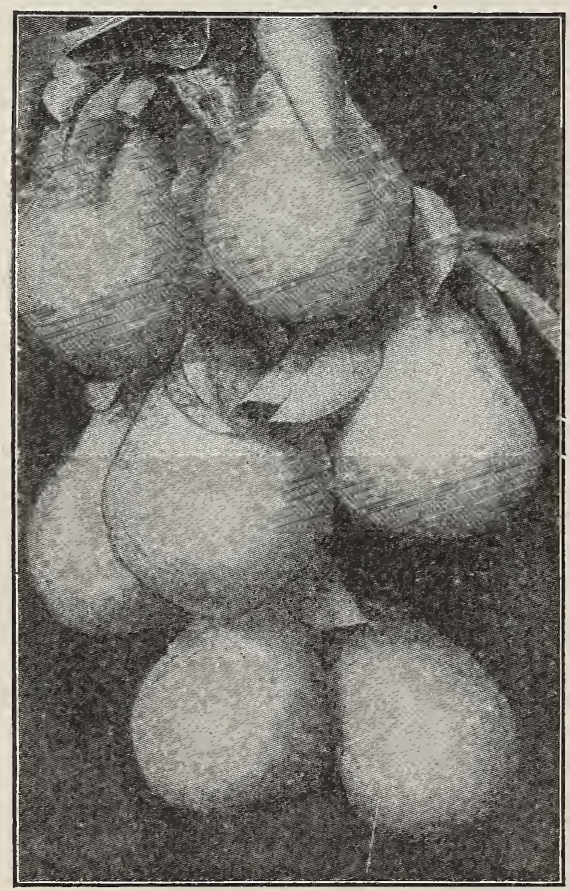

LAWRENCE PEARS

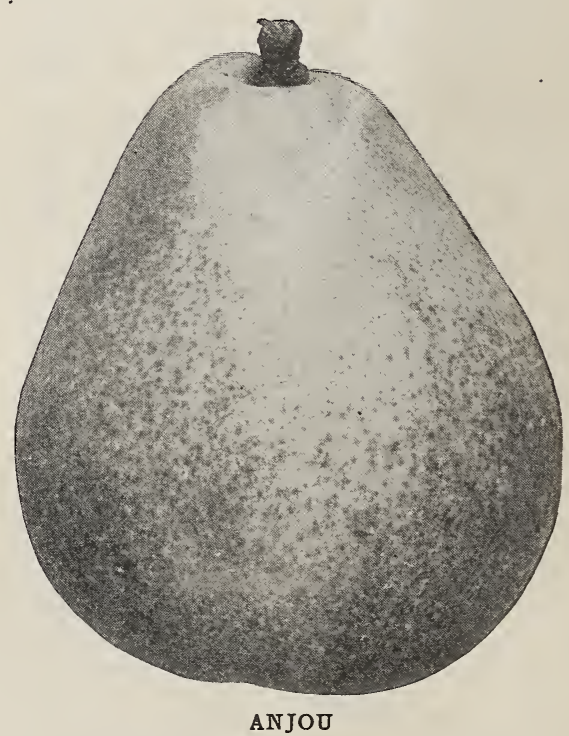

\section{AUTUMN AND WINTER}

Beurre Anjou-A large, handsome pear; buttery and melting, with sprightly, vinous flavor. Keeps until the winter holidays. Considered the best pear.

Beurre Bosc-A large and beautiful russety pear; very distinct, with a long neck; high flavored and delicious. September and October.

Beurre Clairgeau-Very large, tender and juicy, abundant bearer. Valuable market fruit.

Duchess d'Angouleme-Very large; of a greenish yellow, with patches of yellow and a dull red clieek. It attains its greatest perfection as a dwarf. October and November.

Garber-One of the Japan Hybrids; earlier and larger than Kieffer; hardy, productive, early bearer. September and October.

Howell-Large, sometimes witl a short neck. Greenish yellow. Grows a large proportion of fine fruit. October.

Kieffer-Very large, bell shaped; light yellow, sometimes with a slight blush; flesh white, crisp, juicy, of slightly quince flavor; of fair quality; exceedingly valuable for cooking or canning, which brings out its best spicy flavor. October to December. 


\section{OF N UR SER Y S TOC K}

Lawrence-Above medium size, yellow, tender and melting, quality best. Midwinter.

Sheldon-Large size; roundish: greenish yellow, mostly covered with thin, light russet; very juicy, melting, sweet and vinous. October and November.

Seckel-Small size: yellowish russet, with a red cheek. The richest and finest variety known. September and October.

Vermont Beauty-A beautiful pear; of medium size; round, skin yellow, nearly covered with carmine, flesh melting, sprightly, very good. Tree hardy, healthy and very productive. October.

Winter Nelis - A delicious greenish yellow pear; fine grained, juicy and much sought for in markets. November.

Worden Seckel-A seedling of Seckel. Fruit medium size, borne in clusters, juicy, buttery, fine-grained, with a flavor and aroma fully equal to that of its parent, which it surpasses in size, beauty, and keeping qualities. Ripens in October, but will keep in good condition till December.
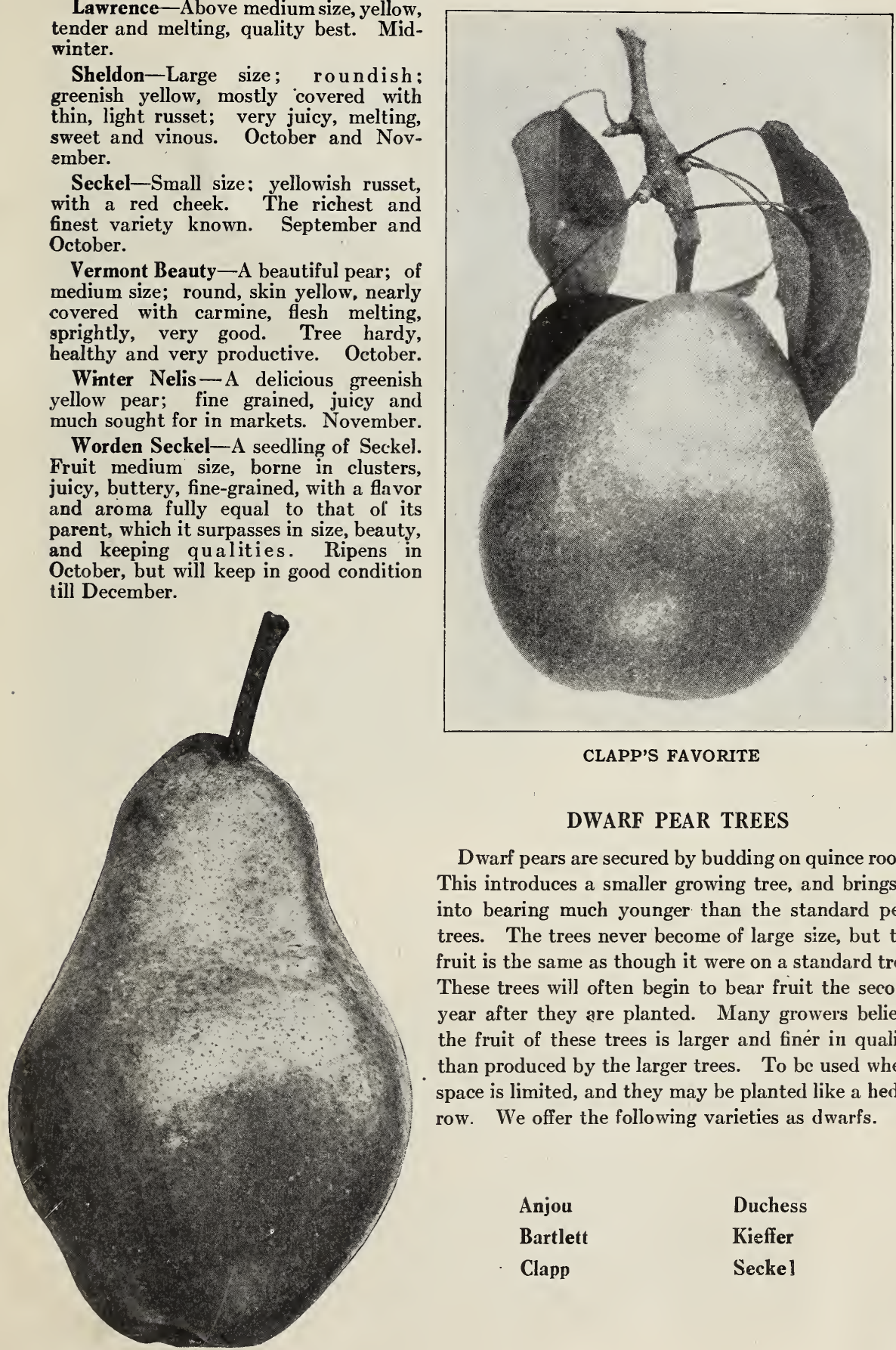

CLAPP'S FAVORITE

\section{DWARF PEAR TREES}

Dwarf pears are secured by budding on quince roots. This introduces a smaller growing tree, and brings it into bearing much younger than the standard pear trees. The trees never become of large size, but the fruit is the same as though it were on a standard tree. These trees will often begin to bear fruit the second year after they are planted. Many growers believe the fruit of these trees is larger and finer in quality than produced by the larger trees. To be used where space is limited, and they may be planted like a hedge row. We offer the following varieties as dwarfs.

$\begin{array}{ll}\text { Anjou } & \text { Duchess } \\ \text { Bartlett } & \text { Kieffer } \\ \text { Clapp } & \text { Secke }]\end{array}$

BARTLETT 


\section{PEACH TREES}

PEACH FRUIT is produced on wood of the last season's growth, hence the necessity for keeping up a good supply of vigorous annual shoots all over the tree. Keep the ground clean and mellow around the trees. Keep the heads low-the trunk ought not to exceed 3 feet in height. Every spring prune and shorten the shoots of the previous year's growth; keeping the head round, full, and well furnished with bearing wood. Cut weak shoots back about onc-half, strong ones, onethird; but sec that you have a suffcient supply of fruit buds.

\section{PEACH VARIETIES}

Admiral Dewey-A perfect freestone, of fine size, form and color, with delicions yellow flesh that is yet firm enougl to ship well. The tree is a strong, liardy, symmetrical grower and prodinces well. Freestone. July.

Alexander - Ripens very early. Large; color deep maroon, handsoinely shaded; flesh firm, rich and good; most excellent shipper; freestone. Middle to last of July.

Belle of Georgia-A very large peach of exceptionally ligh quality, resembling Elberta in shape, with white skin and flesh and liandsome red cheeks. Free. September.

Carman-A new, hardy, rot-proof peach, Large, round; pale yellow skin and red blush on sunny side; white flesh, swett flavor.

Chair's Choice--Large, deep ycllow, red cheek; firm. October 1st.

Champion-Handsome creamy white with red clieek. It is of large size and of very superior flavor. Ripens about August 1, and has shown that it bears a full crop when others fail.

Crawford's Early-This very beautiful and best of ycllow peaches is highly esteemed. Fruit very large, skin yellow, with a fine red cheek; flesh yellow, juicy, sweet and excellent. Freestone. Last of August.

Crawford's Late-Fruit of the largest size; skin yellow, or greenish yellow, with dull red cheek; flesh yellow; productive. One of the finest late sorts. Freestone. Last of September.

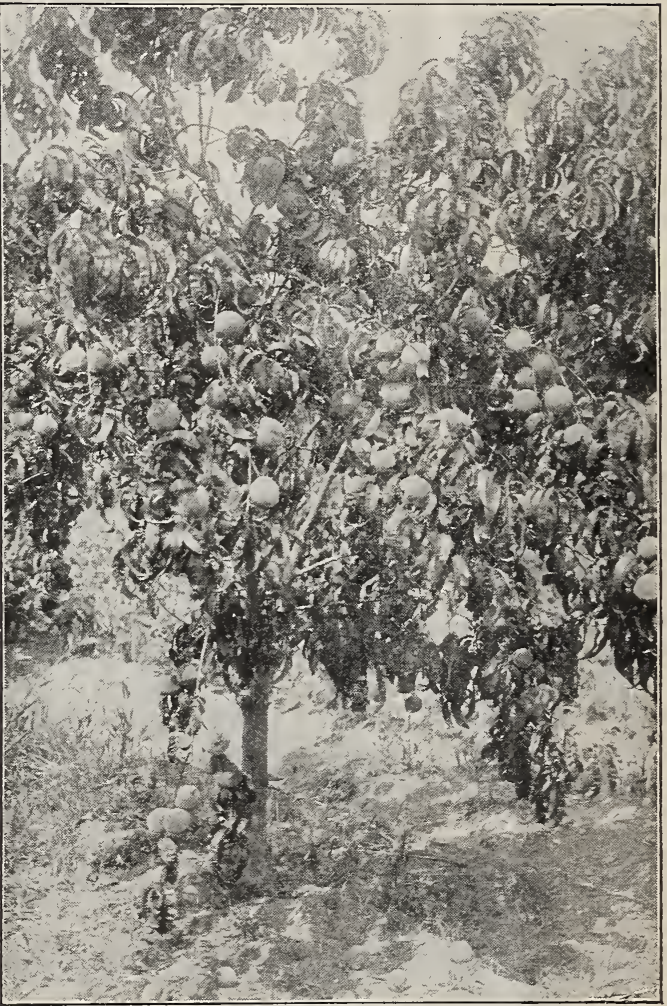

FITZGERALD

Crosby-A beautiful yellow freestone peach with very small pit. Excellent flavor, large size, color orange-yellow, with carmine on the sunny side. Very beautiful; ripens between early and late Crawford.

Elberta-A seedling of Chinese Cling but entirely free. Large; yellow with red cheek; juicy and of high quality; flesh yellow and melting. Ripens after Early Crawford. Freestone.

Fitzgerald-A native seedling, as large or larger than Crawford; freestone, very best quality. A heavy bearer, fruiting very young, almost invariably the second year after planting. Very hardy. Ripens just after Crawford's Early.

Foster-Large, resembling Crawford's Early but of better quality. Early September. 


\section{OF N U R S E R Y S T O C K}

Globe-Fruit exceedingly small, globular in form, of a rich golden yellow with a red blush; flesh very firm, juicy, yellow shaded with red tinge toward the pit. Freestone. Middle of September.

Greensboro--Ripens with Alexander, but is twice the size of that variety. Bright red on a yellow ground. It ripens perfectly to the pit, from which it parts freely when matured. Flesh white, juicy and good. July.

Hiley-Probably the best white peach of its season. Large handsomely colored fruit with distinct pleasant flavor. Very productive. Free. Anginst.

J. H. Hale-Fruit fully one-half larger than Elberta. Color a deep golden yellow overlaid with briglit carmine; smooth, solid thick skin; flesh deep yellow, fine grained, firm and as solid as a cling, yet parting freely from the pit. A peach without the fuzz and distinctive in every respect.

Iron Mountain-Fruit very large, white, freestone, quality good. Very hardy in bud. White inside at pit. September.

Mayflower-Productive and an early bearer. Juicy and tender for such an early peach. White flesh; freestone. Last of July.

Mountain Rose-Very hardy, large, red, flesh white, juicy, rich and excellent; free. August.

Niagara-Large, beautiful and luscious. It has shown complete freedom from blight and other forms of decay. Early September.

Old Mixon Free-Large, pale yellow, with red cheek; tender, rich and good. September.

Rochester-Very large, orange yellow, with deep red blush. Very juicy, highly flavored. Productive; freestone. Middle of August.

Salway-Fruit large, roundish; deep yellow with red cheek, flesh yellow, juicy, rich and sugary. A good keeper. Freestone. First of October.

Smock-Rather large, yellow with a red cheek; flesh yellow, red at the stone. Productive. October first. Freestone.
Stevens' Rareripe-Very productive and of high color; ripens immediately after Late Crawford, and continues three weeks.

Stump-Very large, roundish; skin white, with a bright red cheek; flesh white, juicy and good. Freestone. Last of September.

Triumph-A strong grower and a sure and abundant bearer. Large size, and bright yellow color. Ripens early and young trees liave borne over a half bushel of fruit each. August.

Wheatland-Large; golden yellow, with crimson; juicy, sweet and of fine quality. Ripening middle of September.

Willet-Undoubtedly one of the largest and finest peaches grown. Flesh yellow, skin covered with dark red. Season September.

Yellow St. John-A grand peach, ripening about ten days after Hale's. Nearly as large as Crawford. Bears young and produces abundantly. August.

\section{APRICOTS}

\section{AMERICAN VARIETIES}

Harris-Free; hardy; comes into bearing young, and very productive. Fruit large, rich golden yellow; ripens middle of July.

Montgamet-A large, red and yellow apricot, ripening about August 10th.

Moorpark-One of the largest; orange, with a red cheek; firm, juicy, with a rich flavor; very productive. August.

\section{RUSSIAN VARIETIES}

Alexander-Tree hardy; an immense bearer; fruit large, yellow, flecked with red; very beautiful, sweet and delicious. July.

Gibb-Tree hardy and symmetrical; a good bearer; fruit medium, yellow; sub-acid, rich, juicy, the best early variety, ripening about with strawberries; last of June.

J. L. Budd-A hardy, strong grower and profuse bearer; large, white with red clieek; sweet, juicy, extra fine, with a sweet kernel as fine flavored as the almond; the best late variety. August.

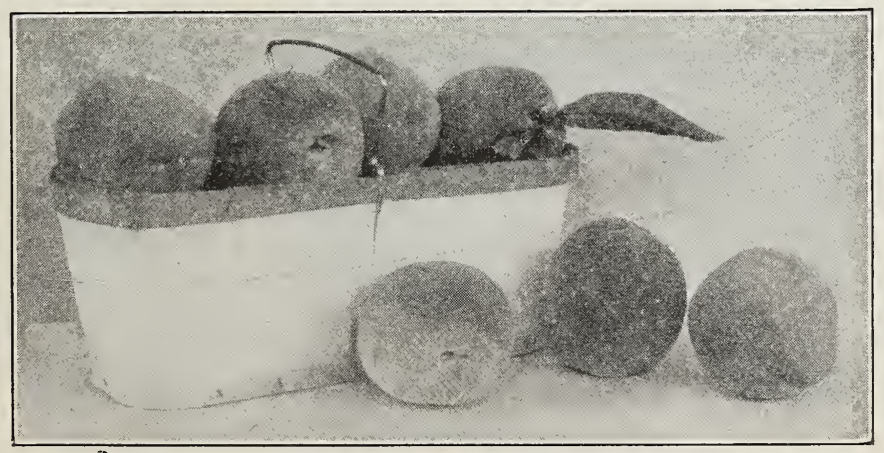




\section{QUINCES}

The Quince is highly valued for preserves, marmalades, jellies and flavoring purposes, and is worthy of more extensive planting. Thrives in warm fertile soil, and the quality of the fruit improves with cultivation.

Bourgeat-Rich golden color; smooth skin, with delicious quince odor.

Champion-Fruit very large; flesh cooks tender. Tree vigorous; bears young; season two weeks later than the Orange; keeps until January.

Meech's Prolific-Ripens between the Orange and the Champion. Bears early. Good quality and large size.

Orange-Fruit large, round, with a short neck; color bright yellow: flesh firm and tough until cooked, when it becomes tender, juicy, and of excellent flavor.

Rea's-The largest and in every respect the finest variety of the quince.

Van Deman-A fine quince, one of the largest; rich orange color; chunky shape; especially good quality; bears young.

\section{GRAPE VINES}

In trimming grape vines remember this-that the fruit is borne at the base of this year's shoots coming from wood formed last year. Pruning should be done in March, cutting off last summer's wood growth so as to leave only two or three buds, from which this year's fruit will be produced.

\section{BLACK GRAPES}

Campbell's Early-Clusters large and handsome; berries large, nearly round, black, with light purple bloom; flesh rather firm, but tender; quality rich, sweet, slightly vinous: a strong and vigorous grower; it ripens rery early.

Concord-A popular variety; universally healthy, vigorous, and productive; flesh somewhat buttery, moderately juicy and sweet. Bunch large, nearly black with bloom; early: September.

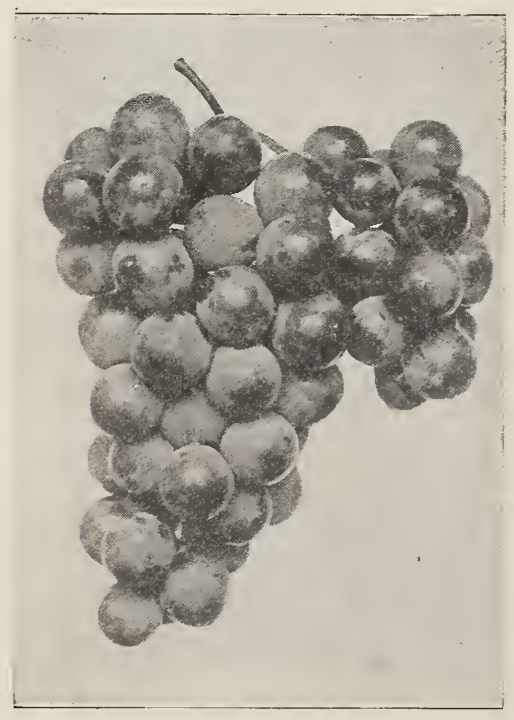

WILDER GRAPE
Moore's Early-Combining the vigor, health and productiveness of Concord. In quality hardly to be distinguished from it. Bunch large, berries very large, black. August.

Wilder-Large; bunches generally shouldered; berry round and large; flesh buttery, with a somewhat fibrous center; sweet, rather sprightly, black. Middle of September.

Worden-Bunches large, handsome; berries large, sweet. Ten days earlier than the Concord, and superior to it in flavor; ripens well in cold localities.

\section{RED GRAPES}

Agawam (Rogers' No. 15)-Dark red or maroon; bunches compact, very large, berries large; oval, pulp soft, fla vor sw eet and aromatic. Ripens early; is very attractive. One of the best of the red varieties.

Brighton-Dark red. One of the most desirable of the early red grapes. Very large and handsome. Clusters under favorable conditions are more uniform than those of any other grape.

Catawba-Bunches large, shouldered; berries large, reddisl and sprightly. One of the old and popular grapes, extensively planted in some sections for wine, for which it is valuable, and for its late kccping qualities.

Delaware-Superior as a table grape. Bunch medium, very compact, berries medium round; skin thin, of a beautiful dark red color when fully ripe; flesh tender and juicy, exceed. ingly sweet. Ripens early in September.

Salem-Chestnut color; bunch large, short, broad and compact, berry very large, round; flesh nearly free from pulp, sweet, aromatic and well flavored; vine vigorous, healthy and productive. Ripens with Concord. 


\section{WHITE GRAPES}

Empire State-Pale yellowish green, hardy. very juicy and tender, one of the best green table grapes.

Green Mountain (Winchell)-Vine strong, vigorous, healthy, very hardy and productive. Bunch long, compact shoulder, green or greenish white. Skin thin. Pulp very tender and sweet. Three weeks earlier than Concord.

Moore's Diamond-It is a prolific bearer producing large, handsome, compact bunches. Color greenish white, with a rich yellow tinge when fully ripe; few seeds, juicy. Berry about the size of a Concord. It ripens from August 25th to September 10th.

Niagara-Bcrries large, skin thin but tough, pale green at first, changing to pale yellow when fully ripe, with a thin white bloom; flesh pulpy, tender, sweet. Ripens with the Concord.

Pocklington-Bunch medium to large, berry large, round, light golden yellow when fully matured; flesh pulpy, juicy. Ripens with Concord.

\section{BLACKBERRY PLANTS}

Blackberries fruit this year on canes which grew last year, and which are worthless after they have once fruited. Remove the old canes each winter.

Ancient Briton-A vigorous, hardy variety; very productive good quality, a fine berry for the home garden.

Blower-Large size, jet-black, good shipper, best quality, unexcelled productiveness.

Eldorado-The vines are very hardy and vigorous, enduring the winters of the far Northwest without injury. The berries are large, jet black, borne in large clusters and ripen well together.

Erie-Fruit very large, excellent quality, handsome and firm and ripens early; fruit uniform both in size and shape.

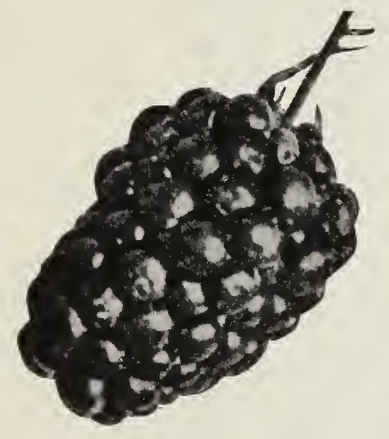

EL DORADO

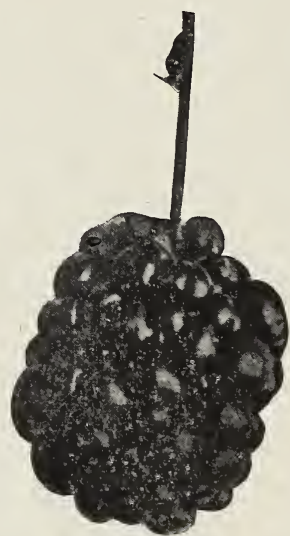

MERSERSAU

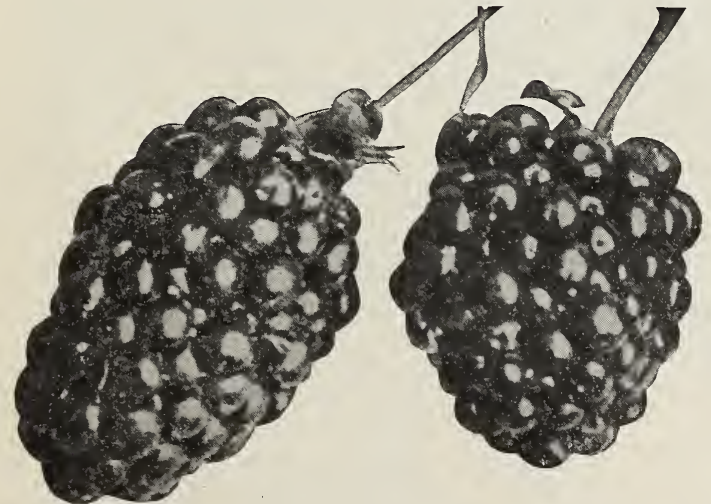

BLOWERS
ANCIENT BRITON

Mersersau-Fruit rather large size, handsome black color, juicy, sweet and good quality. Ripens early.

Rathbun-The fruit is borne in clusters; berries very large, color intense black with a high polish; sinall seeds; flesh juicy, high flavored, sweet and delicious. In season medium early.

Snyder-A marvel for productiveness; fruit medium size; sweet and melting to the core.

Taylor-Sweet, well flavored, hardy, two weeks later than Snyder. Not quite so productive as Snyder, but one of the best late ripening sorts.

\section{DEWBERRIES}

Lucretia-The plants are prefectly hardy and healthy, and remarkably productive. The truit is very large, soft, sweet and luscious throughout, without any hard center or core. 


\section{RASPBERRIES}

\section{RED AND YELLOW VARIETIES}

Columbian-One of the most vigorous growers of the red raspberry family. Fruit very large; shape conical, color dark red, bordering on purple. Wonderfully prolific and perfectly hardy.

Cuthbert or Queen of the Market-Fruit is large, luscious, and produced in the greatest profusion. Color deep rich crimson; fruit very firm. Ripens from July 10 to 20 , and continues a long time in fruit.

Golden Queen-Fruit large; color a pure yellow; quality best. Ripens with Cuthbert.

Herbert-Fruit large, bright red, somewhat oblong, the largest of red raspberries, very hardy. Flavor sweet and juicy. Season five or six days before Cuthbert.

June-Very excellent red raspberry. A new variety propagated by N. Y. Experiment Station and recommended by them. Good both for canning and table use.

London-Large fruit, dark crimson, good quality.
Marlboro-Color a bright crimson and unlike others, does not lose its brilliancy when over ripe; of a good quality and very prolific.

St. Regis-One of the greatest raspberries ever introduced. Plants of the St. Regis put out in the Fall or early April gave ripe berries on the 20th of June. For four weeks thereafter the yield was heavy and the canes continued to produce ripe fruit without intermission until late October. The berries were large and beautiful, firm and full flavored to the very last.

Thompson Red-The best early red. Hardy, vigorous, productive.

\section{BLACK RASPBERRIES}

Black Diamond-Berries large, very sweet and pulpy, yet fine for shipping and evaporating. Canes strong and fruitful. Early.

Cumberland-The bush is hardy, a vigorous grower, and exceptionally productive. Fruit of uniform size, and larger than any known black raspberry.

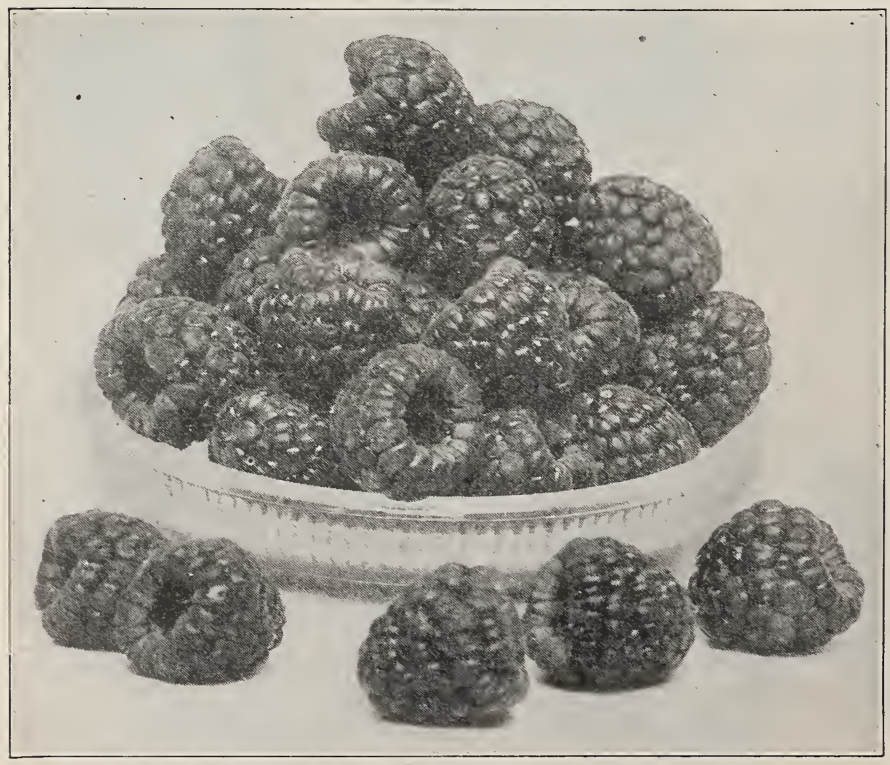

CUTHBERT

Gregg-Jet black never falls from the bushes, and of first quality; canes of strong growth, perfectly hardy and immensely productive.

Kansas - Large, round, firm and juicy. Similar to Gregg, but earlier and hardier.

Ohio - A strong, very hardy growing sort. A productive market variety, and esteemed for drying.

Plum Farmer One of the very earliest Blacks. High quality, very productive and hardy.

\section{ASPARAGUS}

Conover's Collossal-A well-known and popular variety.

Palmetto-A very early variety; even, regular size of excellent quality.

\section{RHUBARB}

Every garden should have a few plants of rhubarb. Plant any time, burying the whole plant about three inches in the ground.

Myatt's Linnaeus-Of superior quality; tender, with a mild sub-acid flavor. 


\section{OF N U R S E R Y S TOC K}

\section{CURRANTS}

Cherry (Red)-Very large; deep red; rather acid; bunches short.

Fay's Prolific-(Red) of large size, fine flavor and twice as prolific as the Cherry.

Perfection (New) - Color, bright red. Larger than Fay and Cherry. Very productive. Quality fine. Not so acid as Fay.

White Grape-The finest of the white sorts.

Wilder-A red currant, productive to the highest degree. Excellent in size and quality.

\section{GOOSEBERRIES}

Downing-Favorite American variety; pale green and covered with a white bloom; best in flavor and quality; a strong grower, productive and liealthy; valuable for market.

Houghton-A medium sized American variety, which bears abundant and regular crops, and never mildews; fruit smooth, red; tender and very good; valuable.

Josselyn-Good grower, fine foliage and a very profitable fruiter when compared with any other gooseberry in existence.

Pearl-The color is light green and quality first class. Being thoroughly tested, we offer it as the best of its class yet grown.

Smith's Improved (American)-Color yellow, large, excellent quality, pulp sweet and good.

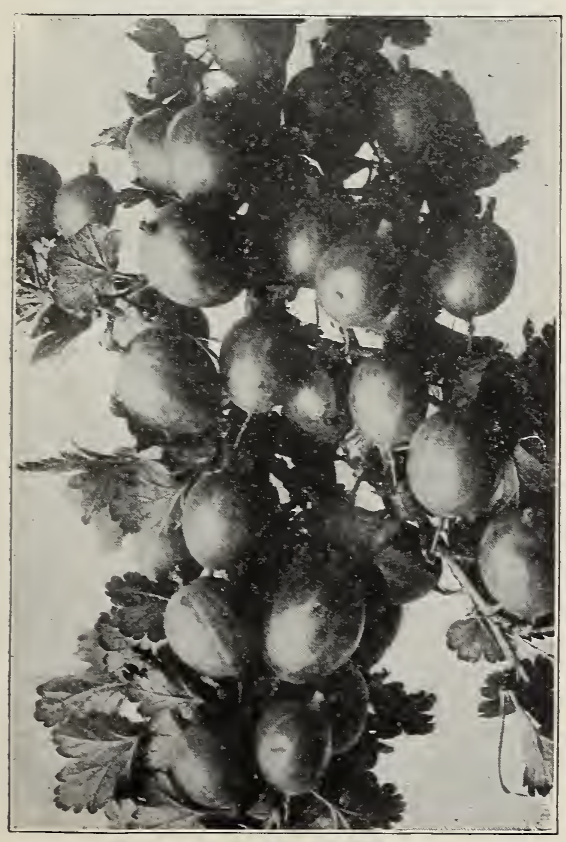

PORTAGE GOOSEBERRY

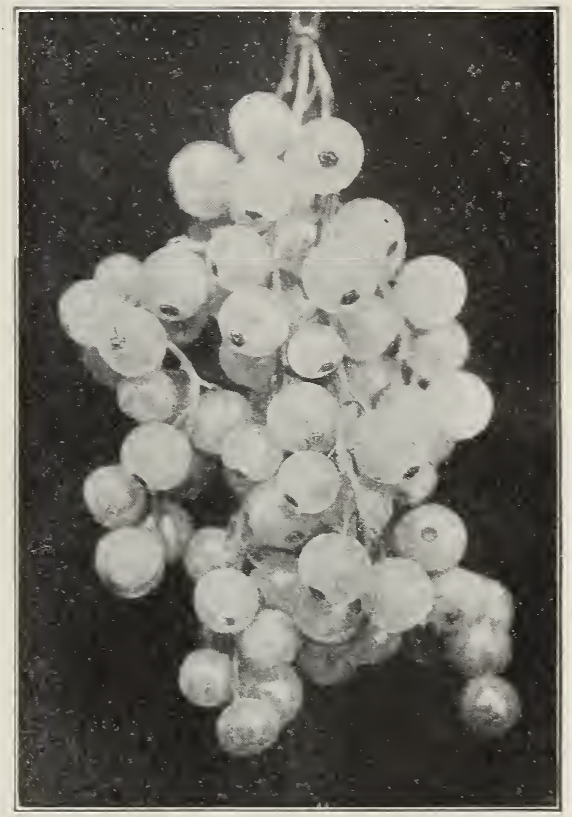

WHITE GRAPE CURRANT

\section{MULBERRIES}

Downing's-The beauty of this as a lawn or street tree is quite enough to commend it, but in addition it yields an abundant supply of its large refreshing berries for about three months.

Russian-A hardy, rapid-growing tree. Fruit of little value.

\section{NUT TREES}

Chestnut, Spanish-A handsome, roundheaded tree, producing large nuts in large quantities.

Filbert-A profitable and satisfactory nut to grow. The nuts are rich and of excellent flaror.

Walnut, Black-One of our most valuable nut trees, the timber being highly prized for many purposes, whil the nut meats are sought after for the peculiar richness and flavor which characterizes this variety. The Black Walnut has considerable importance as a shade tree.

Walnut, Common English-These trees should be more generally planted in the Eastern states. They make attractive, thrifty trees and produce nuts of great value. 


\section{STRAWBERRY PLANTS}

\section{PERFECT AND IMPERFECT FLOWERS}

Bederwood (Per.) - Berries large, of regular, roundish form, light scarlet, excellent quality, remaining in fruit a long time.

Bubach (Imp.) - P. A. sterling old sort that combines many excellent qualities; great and uniform size, rich color and quality, extraordinary vigor and fruitfulness, fine foliage that endures the hottest suns. Season early to medium.

Brandywine (Per.) - One of the very reliable fruiting sorts that can be depended on for heavy crops on a variety of soils. Berries very large, broadly heart-shaped, bright red to the center; firm-fleshed and finely flavored. A valuable late berry.

Chesapeake (Per.)-Berries very large, regular in shape, glossy and attractive. One of the best market sorts because of its good looks.

Crescent Seedling (Per.)-Good size, a strong grower, very productive; one of the best for market and garden.

Clyde (Per.)-One of the very best medium early varieties, a week earlier than Bubach, and very firm; large, bright scarlet berries of fine flavor. Plants stand drought well, free from rust and disease.

Gandy (Per.)-The popular, late market berry always commanding fancy prices.

Glen Mary (Per.) - A fine, large, late berry of excellent quality.

Marshall (Per.)-Berries are beautiful and a verage very large. The color is a rich glossy crimson that everyone admires-the surface color running well into the flesh, and the quality is far above the average.

Michel's Early (Per.)-'The first variety to ripen here; berry medium to large, roundish, bright crimson, firm, fair quality; plant a strong grower and a good bearer. A fine sort to pollenize early pistillates.

Sample (Imp.) - In productiveness it is perhaps surpassed by none. The fruit is very large. Of fine quality but not the best.

Sharpless (Per.)-One of the best strawberries in cultivation. Possesses ALL the good qualities looked for in a stra wberry. A strong grower, productive and largest size.

Senator Dunlap (Per.) - Very productive. Large, bright, or slightly dark red. Quality the very best.
Steven's Late Champion (Per.)-Large, light red berries, pointed globular; regular and perfect in form; very firm and of extra high quality. An ideal plant to produce large berries and yield an enormous quantity of them. Season late.

Warfield (Imp.) - Similar to Dunlap, and a good variety to grow with it. Very hardy and succeeds everywhere. Productive and a good shipper.

Wm. Belt (Per.)-Very large conical; color bright red; quality very good. Season medium to late.

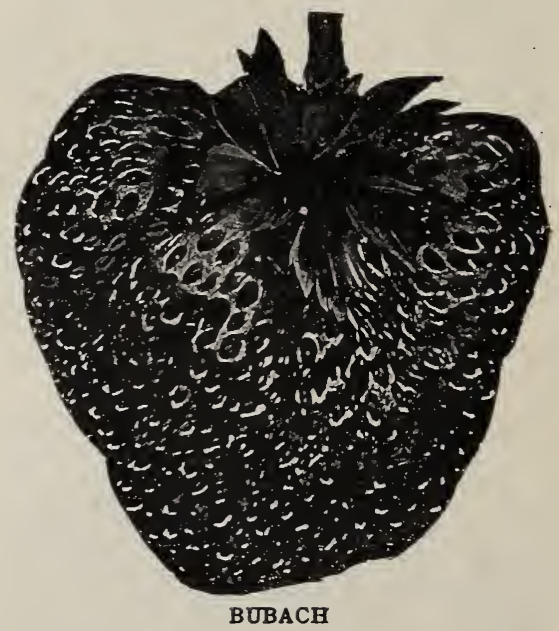

\section{EVERBEARING VARIETIES}

Superb-These plants are very vigorous growers and produce wonderful crops when the runners are restricted; but if the runners are allowed to grow, the crop on most of the plants wiil be light. The young runners do not bear the first year, but bear a good crop the second year, both spring and fall. In the spring it is more productive than most summer bearing kinds, while the fall crop is more beautiful even than the summer crop.

Progressive-This does best on soils that dry quickly after rain. The berries are medium size about like Dunlap. The flavor varies depending on the soil and amount of sun shine, but by most people is classed as very good. It succeeds as a fall producer, with more people than other tested varieties. The summer crop ripens the earliest of any strawberry. 

$\mathrm{OF}$
N U R S E R Y
$\mathrm{S}$ T O C K

\section{Ornamental Trees}

\section{FOR SHADE AND ORNAMENTAL PURPOSES \\ Deciduous Trees}

Deciduous trees are those which periodically lose their foliage. Our purpose is to offer here such trees as have particular value for lawn, avenue or park planting. From our list may be selected trees noted for symmetrical shape, irregular shape, compact head, open head, majestic size, dwarf size, beautiful bloom, and for rich color of foliage. Nature has provided a tree for nearly every purpose and place. Our patrons should observe that many of the ornamental trees are not beautiful or graceful at the age at which they are sold and planted. This is beyond the control of the nurseryman. Trees planted and given time to develop will give satisfactory results.

ALMOND (Prunus Sinensis)

Dwarf Double Rose Flowering (A. Japonica f. rubra pl.) - A small shrub, producing in May, before the leaves appear, small, double rose-like flowers, closely set on the branches.

Dwarf Double White (A. Japonica fl. alba pl.)-Produces beautiful white flowers in May.

ARALIA (Angelica Tree or Hercules Club)

Spinosa-A native plant valuable for producing tropical effects, having prickly stems, pinnate leaves and bearing immense panicles of white flowers in August.

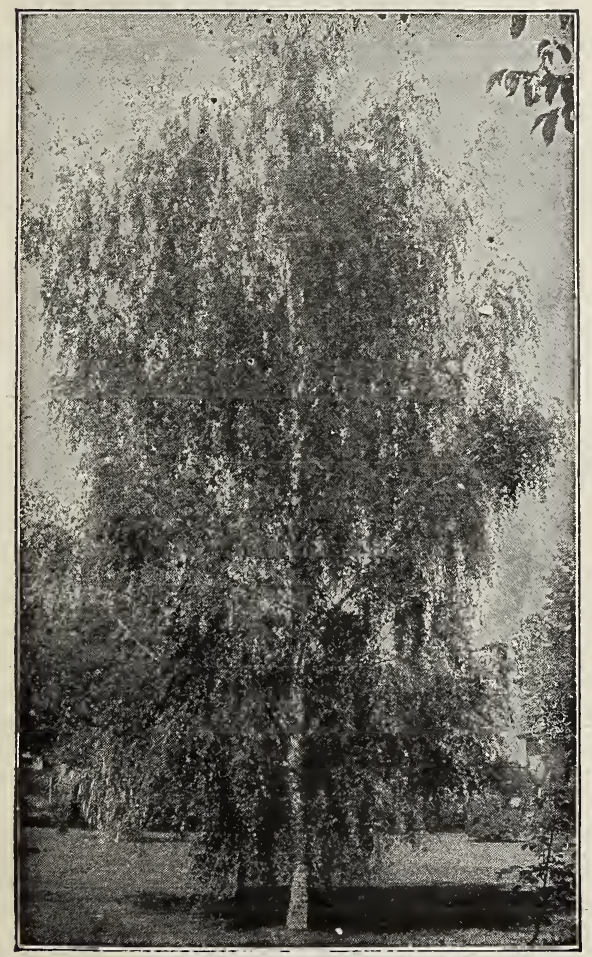

WEEPING CUT-LEAF BIRCH

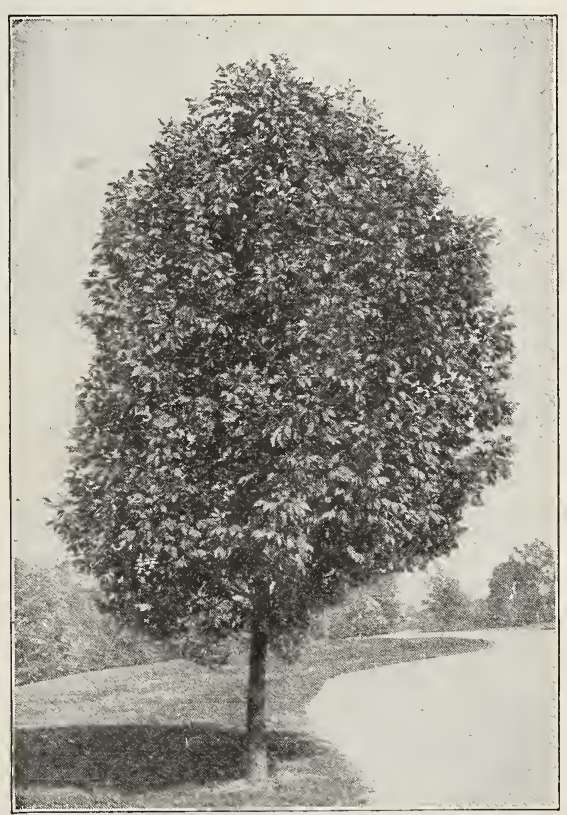

AMERICAN WHITE ASH

\section{ASH (Fraxinus)}

European Flowering (F. Ornus)-Flowers greenish white, fringe-like, appearing only on the ends of the branches. Blooms early in June.

White (Alba)-The native ash.

\section{BEECH (Fagus)}

American (F. Ferruginea)-A well-known native sort.

Purple-Leaved (F. purpurea)-Dark purplish foliage, making a striking contrast with the green of other trees.

Rivers-Crimson foliage early in the spring, changing to a dark purple in summer. The finest of all purple-leaved trees. 


\section{BIRCH (Betula)}

Graceful and suitable for any lawn. Hardy and thrifty in all soils.

Canoe or Paper Birch (B. Papyracea)-This magnificent tree has gathered about it more poetic associations than any other native tree.

Common White (B Alba)-A well-known variety, making a vigorons, erect growth, and having long, slender branches. Very desirable.

Cut-leaved - Weeping (B. Pendula lacimiata)-This tree is indeed a picture of delicacy and grace. Makes a large tree.

Young's Weeping (B. Pendula Youngii)-The fine thread-like shoots droop to the ground forming a picturesque tree.

\section{CATALPA}

C. Bungei-A small species 8 to 10 feet high, clothed with a dense mass of large, heart-shaped leaves.

C. Speciosa-This is a tropical looking tree, and flowers in July, when few trees are in bloom. A very attractive lawn tree.

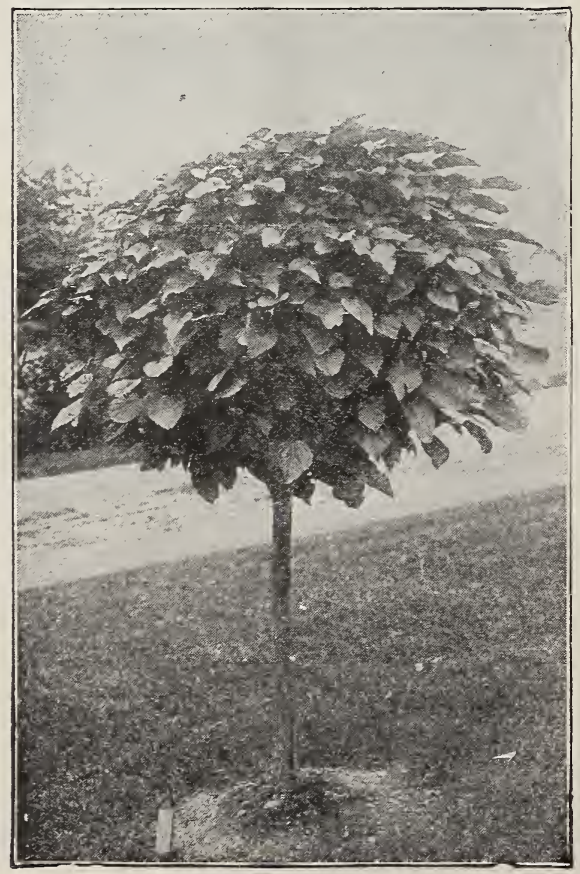

CATALFA BUNGEI

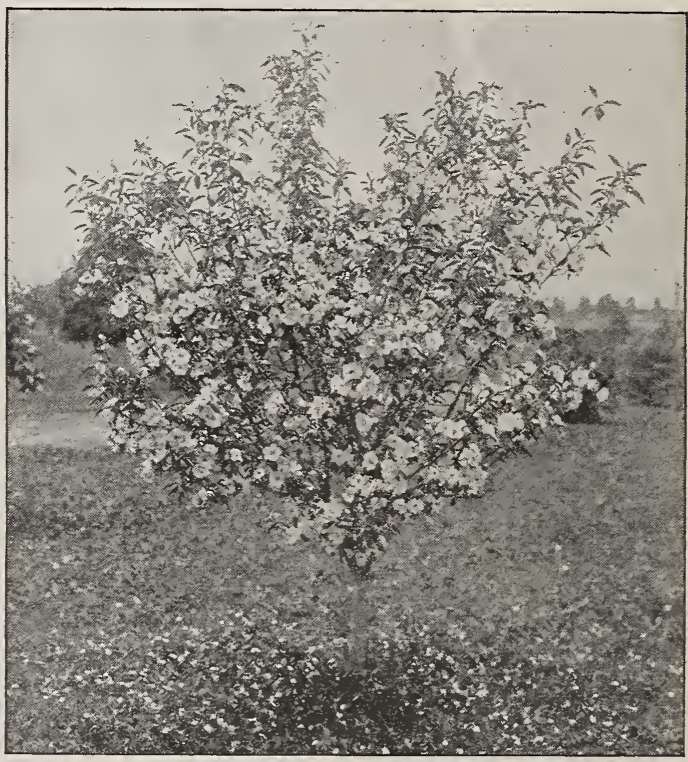

BECHTEL'S FLOWERING CRAB

\section{CHERRY (Cerasus)}

A handsome ornamental tree, especially adapted for small grounds.

Chinese Double Flowering (Sinensis Flore Plena) - A valuable variety, with large double white flowers.

\section{CRAB (Pyrus) \\ Bechtel's Double Flowering Crab-A} medium-sized, ornamental tree of great beauty. When in bloom this tree presents the appearance of being covered with pink roses. Flowers large, fragrant and beautiful.

Floribunda-Flowers crimson, produced in great profusion. A charming variety.

\section{DOGWOOD (Cornus)}

White Flowering (Florida)-Foliage of a grayish green color; turning in the autumn to a deep red. The flowers appear before the leaves in the spring and are about three inches in diameter; white and very showy.

Red Flowering (Flora Rubra) - A valuable variety, producing beautiful carmine flowers.

\section{ELM (Ulmus)}

American White (Americana)-A native tree of large size, with open, spreading head and graceful drooping branches.

Camperdown Weeping (U. Camperdown pendula)-One of the most satisfactory weeping trees in cultivation. The growth is rapid, the foliage luxuriant; it forms a fine-shaped head, and is very hardy. 


\section{O F N U R S E R Y S TOC K}

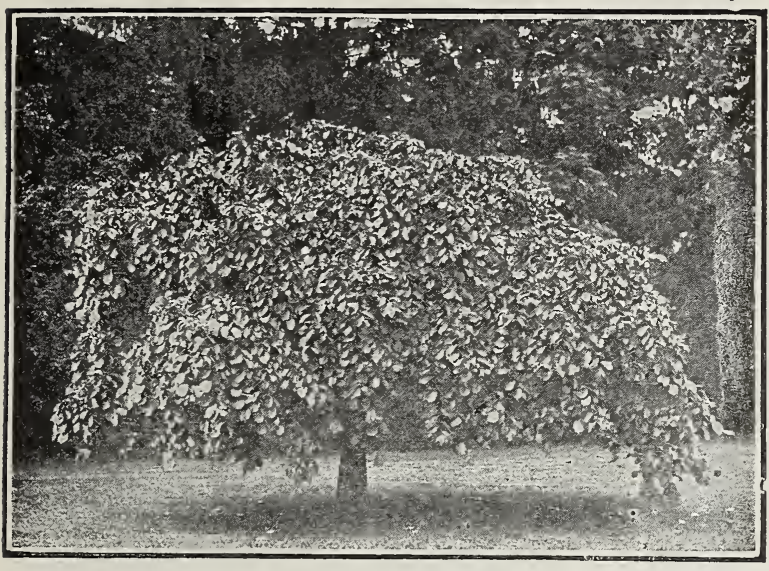

CAMPERDOWN ELM

LINDEN OR LIME (Tilia) American, or Basswood (Americana) - A rapidg row ing, open-head or spreading tree, with large leaves. Very desirable.

European (Europæa)-A very fine pyramidal tree, smaller in all its parts than the preceding.

White-Leaved European (Alba) - A rigorous growing tree, with large handsome foliage, quite downy and whitish underneath; smooth above.

\section{MAGNOLIA}

Cucumber Tree (Acuminata)-A magnificent tree, producing in June yellow flowers, tinted with bluish purple.

English (Campestris) -A native of Europe, forming a tall, erect tree, with slender branches and small leaves.

\section{HORSE CHESTNUT (Aesculus)}

European or White Flowering (Ae. hippocastanum)-A beautiful well known tree, forming a round compact head, with dark green foliage and an abundance of showy flowers in spring.

Red Flowering (Rubicunda)-A splendid tree producing showy red flowers a little later in the season than the white.

Glabra (Ohio Buckeye)-A native of the Western States; leaves smooth; flowers yellow; blooms before the others. 6 to 8 feet.

\section{JUDAS TREE (Cercis)}

American (C. Canadensis) - A very ornamental tree with heart-shaped leaves. Before the foliage appears, it is covered with a profusion of delicate pink flowers, from which it derives its name, Red Bud.

\section{KOELREUTERIA}

Paniculata-A large shrub or small tree, with foliage somewhat resembling that of the Sumach, and producing large panicles of showy flowers in July. Foliage very brilliant in Autumn.

\section{LABURNUM (Cytisus)}

Golden Chain-Bears long, pendant racemes of golden flowers in June. Very showy and beautiful.

\section{LARCH (Larix)}

European (Europæa)-A beautiful, rapidgrewing tree of irregular, pyramidal form, with small, drooping branches.

\section{MAIDEN HAIR TREE OR GINGKO \\ (Salisburia)}

Adiantifolia-A rare beautiful tree from Japan, with remarkable fern-like foliage; distinct and fine.

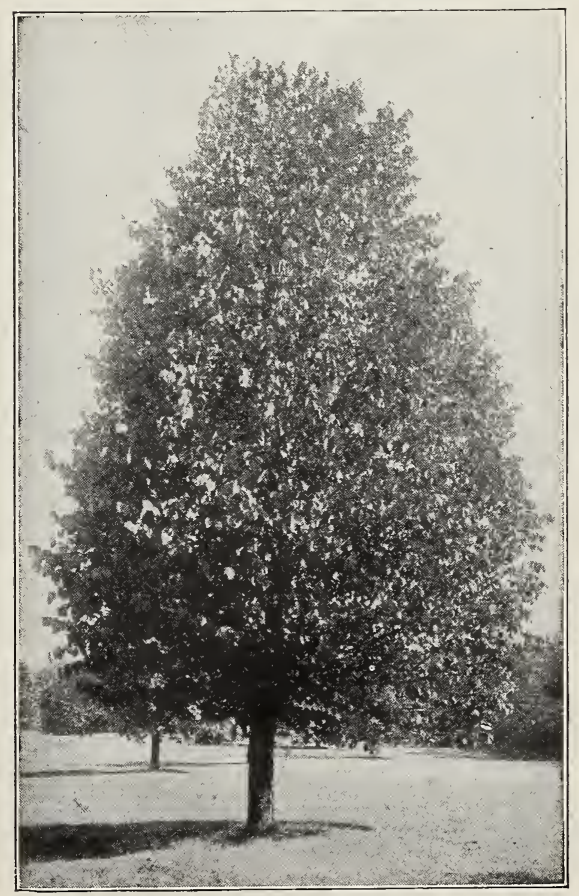

EUROPEAN LINDEN 
[MAPLE (Acer)

Ash-Leaved (Negundo)-A rapid-growing tree, with lea ves and branches of a light green.

Norway (Platanoides)-Very popular on account of its clean, broad foliage of rich, deep green. Stout vigorous grower.

Schwedler's

Norway (Schwedlerii)-Young shoots and leaves of a purplish crimson color.

Silver-Leaved, or White (Dasycarpum) - A hardy, rapid-growing native variety of the largest size; foliage bright green above and silvery underneath. Valuable for producing a quick shade.

Sugar or Rock (Succharinum -A well-known native tree. Desirable as an ornamental shade tree.

Wier's Cut-Leaved (Wierri Laciniatum)-Grows very rapidly, and the shoots are so slender and drooping that it has a decidedly graceful appearance. The leaves are deeply and delicately cut.

\section{MOUNTAIN ASH (Sorbus)}

American (S. Americana) - Of coarser growth and foliage than the European, and having larger berries of a lighter color. White blossoms appear in early spring, followed by clusters of scarlet berries.

European (S. Aucuparia)-Of finer growth and form than the American. It blossoms during the early spring, after which the bright scarlet berries are formed in clusters.

Oak-Leaved (S. Quercifolia)-Very showy whether in bloom or berry. It forms a compact, pyramidal head. The leaves are bright green above and downy beneath. The blossom is white, forming in early spring.

\section{MULBERRY, TEA'S WEEPING}

Perfectly hardy, forming a natural umbrellashaped top or head; foliage handsome; a fine ornamental for the lawn.

\section{OAK (Quercus)}

American White (Alba)-One of the finest American trees, of large size and spreading branches.

Rubra (Red Oak) - A broad tree of rapid growth; large, rich foliage, which turns to a bronzy red in the fall. Deservedly

Scarlet Oak (Coccinea)-A native tree, of rapid growth; pyramidal outline, and especially remarkable in Autumn, when the foliage changes to a bright scarlet.

Pin Oak-A tall, upright growing variety when young, but with age the branches droop. Foliage bright and glossy. One of the best oaks for street planting, and becoming very popular.

\section{POPLAR (Populus)}

Desirable where rapid growth is wanted.

Bolleana-A very compact upright grower, resembling the Lombardy Poplar; leaves glossy green above and silvery beneath. The bark of this variety is of a rich green color, giving a distinct and striking appearance.

Carolina-Pyramidal in form and robust in growth. Leaves large, serrated and pale to deep green in color.

Lombardy (Fastigiata) - Well known for its erect, rapid growth and commanding form.

\section{PEACH (Persica)}

Double Rose-Flowering (P. Flore rosea pleno)-Flowers double, pale rose colored, like small roses. Blooms in May

Double White-Flowering (P. Flore albe pleno) - Exceedingly ornamental. Flowers double and pure white. Blooms in May. 


\section{OF N UR S E R Y S TOC K}

\section{PLANE TREE or SYCAMORE (Plantanus)}

Silver-Leaved, or White (Alba)-Leaves large, green above and pure white underneath. Rapid growth; wide-spreading habit.

Oriental Plane-A lofty, wide-spreading tree; heart-shaped leaves. Entirely free from worms or insects. One of the oldest cultivated trees known.

\section{PLUM (Prunus)}

Prunus Pissardii (Purple-leaved) - A perfectly hardy, small-sized tree or shrub, of elegant appearance. The bark is black, and the leaves a rich purple, gorgeous to behold, retaining their bright color through the entire season. The ends of the growing shoots are brilliant red.

P. Triloba (Double flowering) - A very pretty little shrub, hardy and desirable. The flowers about an inch in diameter, semidouble, of a delicate pink color, appearing in May.

\section{THORN (Crataegus)}

Dense, low-growing trees, and very ornamental when in bloom.

Double White (Alba Pleno)-Flowers small, clear white and desirable.

Paul's New Double (Coccinea Flore Pleno Paulii)-Producing bright crimson and very double flowers. One of the best.

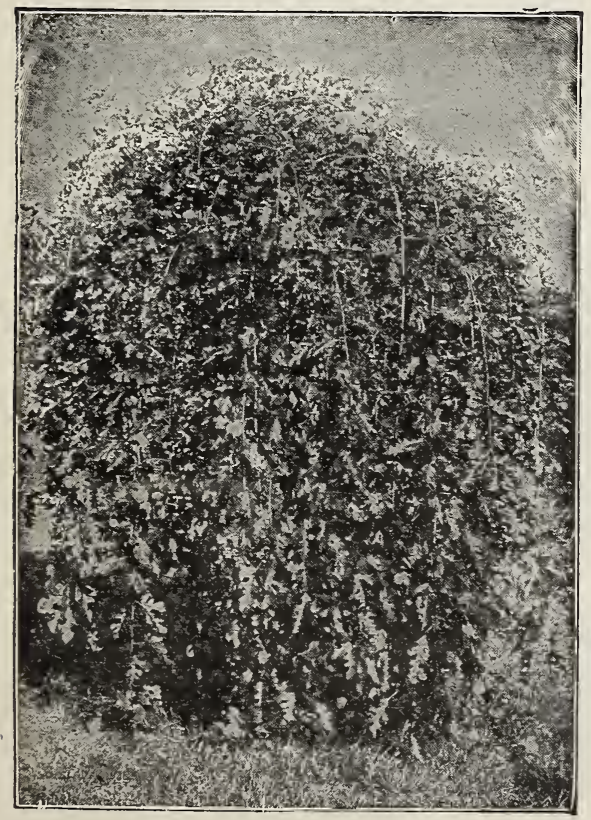

TEA'S WEEPING MULBERRY

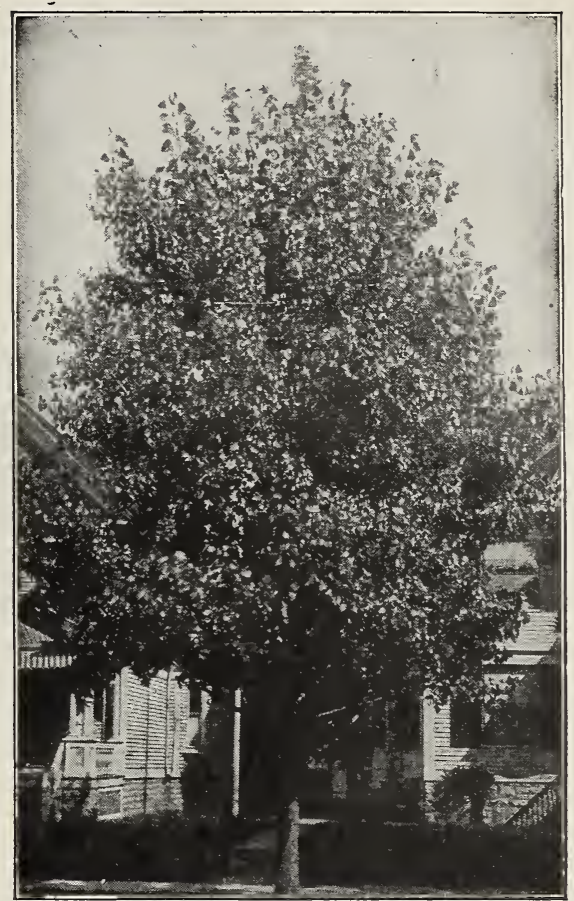

CAROLINA POPLAR

\section{TULIP TREE, or WHITE WOOD (Liriodendron)}

Tulipfera-One of our largest native trees, with large, glossy leaves, shaped like a violin. Very desirable.

\section{YELLOW WOOD (Virgilia Intea)}

One of the finest native trees. Flowers very fragrant, pure white, and produced in long, drooping racemes in June.

\section{WILLOW (Salix)}

American (S. Americana pendula)-A variety with delicate leaves and slender branches. Graceful and ornamental. Never grows large.

Babylonica-Our common and well-known weeping willow.

Kilmarnock (S. Caprea pendula)-The best known of the finer weeping ornamental trees. Its great hardiness, vigorous growth, adaptability to all soils, easy culture, fine form, and unique appearance render it a general favorite.

Thurlow Weeping-Of stately proportions with graceful drooping branches and bright, long glossy leaves. The hardiest and best of the willows. 


\section{Evergreen Trees}

The Evergreens are among the most valuable of our ornamental trees. Their greatest importance is perhaps due to the shades of green they afford during the bleak winter months, when the deciduoustrees are leafless. They are also very valuable as hedge.windbreaks and as screens for hiding undesirable views for or securing privacy.

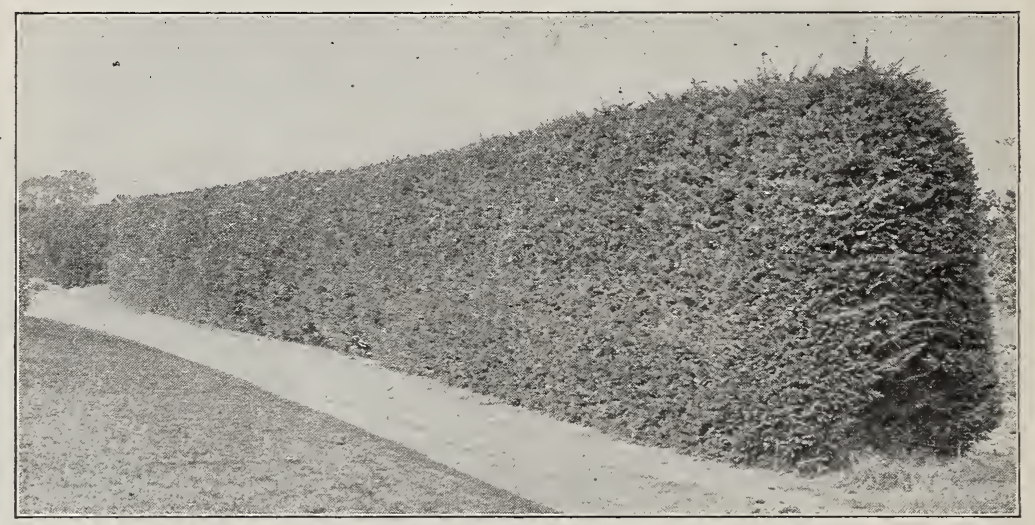

The NORWAY SPRUCE Hedge is Attractive and Effective

\section{ARBOR VITAE (Thuja)}

American (T. Occidentalis) - One of the fine hedge evergreens. Very hardy and easily transplanted. Grows rapidly and stands shearing well.

- var. T. Aurea-Golden foliage; fine as an ornamental specimen or in groups.

- var. T. Compacta-Dense growth of dwarf habit, deep green and very fine in group plantings.

Globe headed (T. Globosa)-Grows in low, thick, globe form with attractive foliage. Its shape makes it a valuable variety.

Hovey's Golden (T. Hoveyii)-A fine American variety with excellent green foliage, globe form and of dwarf growth.

Pyramidalis-Dark green, compact foliage and remarkable erect form; perfectly hardy.

Siberian (T. Sibericus) - Exceedingly hardy, and keeps its fine color well during the winter. Compact growth, making an excellent tree for lawn specimens. One of the very best for ornamental and hedge uses.

Tom Thumb (T. Ellwangeriana)-A dwarf variety of very compact growth, valuable for small enclosures and low growing hedges.

Vervaene's (T. Vervaeneana)-Dense growing foliage which is variegated with yellow, giving the tree a light golden tinge. Much used for hedges near dusty roads.

\section{CYPRESS, JAPAN (Retinospora)}

Filifera-This has slender, string-like, drooping shoots. Quite distinct from any other. It makes a unique specimen evergreen.

Filifera Aurea-A golden form of the preceding.

Obtusa-A charming lawn tree of vigorous growth, assuming a pyramidal outline, yet with a pleasing, open habit and graceful, waving branches.

Obtusa Nana-One of the best and hardiest. Intensely dark, shell-like leaves; very unusual. A most elegant evergreen shrub.

Plumosa-More compact growing than Filifera, and makes a nice ornamental tree.

Plumosa Aurea-One of the best known and most valued of all, because of its golden color. It makes a compact growth of much beauty.

Pisifera-Beautiful tree, with delicate branches and fine, feathery foliage.

Pisifera Aurea-A fine pyramidal, bright golden form; popular and graceful.

Squarrosa-This valued sort has steelcolored foliage and makes a tufty, compact growth. It grows to a large size, but by pruning can be kept down to almost any size, as, in fact, can all Retinisporas. 


\section{OF N UR SER Y S T O C K}

Nordmann's Silver Fir (A. Nordmanniana) -Of symmetrical form, vigorous and quite hardy. Its foliage is massive, dark green, shining above and slightly glaucous below, rendering it a very handsome tree throughout the year.

P. concolor (Silver Fir of Colorado)-The finest of the Rocky Mountain evergreens. Tree of graceful habit; broad, handsome foliage, bluish above, silvery beneath. Very distinct and rare.

\section{JUNIPER (Juniperus)}

Hibernica (Irish Juniper)-Tree with dense pillar-like growth. Glaucous green foliage, with tips of branchlets erect.

Sabina (Savin)-A low, spreading tree with handsome, dark green foliage; very hardy, and suitable for lawns and cemeteries.

Virginiana (Red or Virginia Cedar) - A native form, very common in New England. Tapering, bright, rich green foliage. Bark on trunk and branches reddish brown. Thrives on dry soil.

\section{PINE (Pinus)}

Austrian or Black P. Austriaca)-A robust growing sort. Leaves long, stiff, dark green. Makes a large spreading tree.

Mugho (Dwarf Mugho)-An upright, small, beautiful pine bush.

Scotch (P. sylvestris)-A fine robust, rapid growing tree with stout, erect shoots and silvery green foliage.

\section{SPRUCE (Picea)}

Colorado Blue Spruce-A beautiful variety, the nearest blue of any evergreen; very distinct in foliage and growth; fine, compact, habit. Foliage rich blue or sage color.

Douglas Spruce (A. Douglasii)-From Colorado. Large conical form; spreading branches; horizontal; leaves light green above glaucous below.

Hemlock (A. Canadensis) Delicate, dark colored foliage, and drooping branches Good for lawn, and also makes a good hedge.

Koster's Blue-A selected strain from the bluest tints of the Colorado Blue. This tree is propagated by grafting to preserve the true type, making it much more expensive than seedling trees. One of the most attractive conifers ever introduced, It holds its deep color throughout the year.

Norway (A. excelsa)-Of large and lofty appearance. Well adapted for large enclosures, and stands pruning well. It is exceedingly picturesque and beautiful; very popular and deservedly so. Includes weeping varieties.

American White (A. alba)-A tall tree, loose, spreading branches, and foliage silvery gray. Very bushy and valuable.

\section{TAXUS (Yew)}

Cuspidata (Japan Yew) -A rare and beautiful low-growing evergreen, It is hardy as an oak and remains a deep green through the winter, even when exposed to sun and wind.

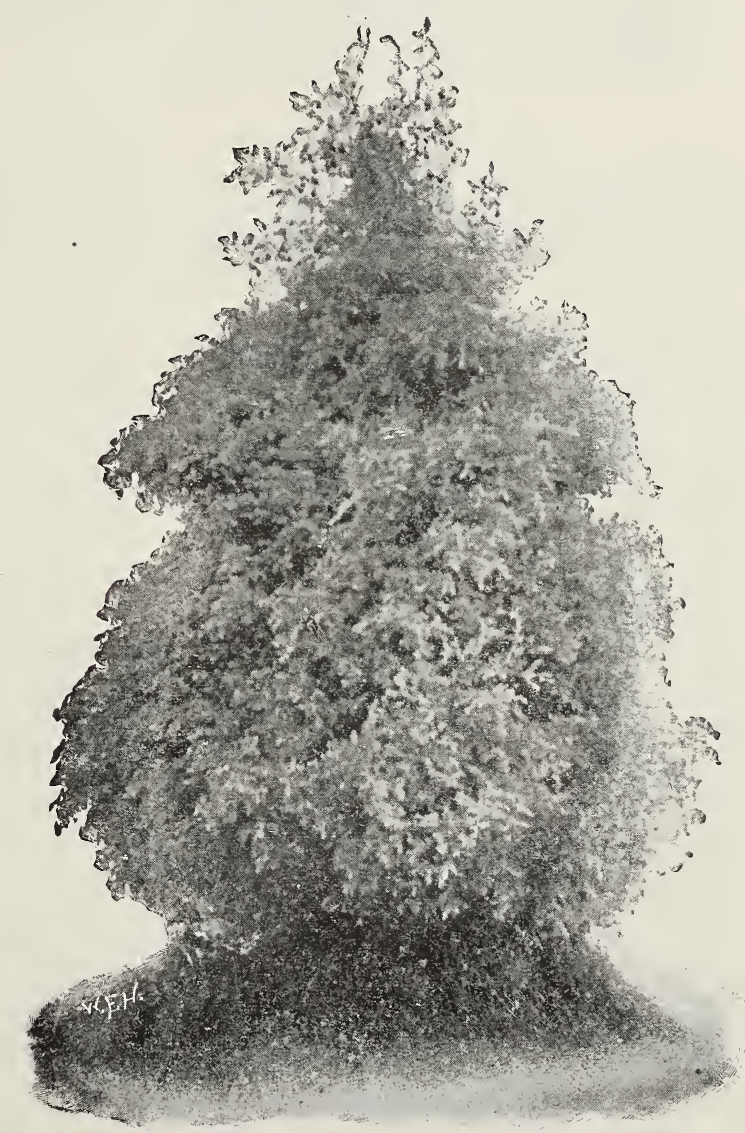

RETINISPORA OBTUSA 


\section{GENERAL C A TALOG}

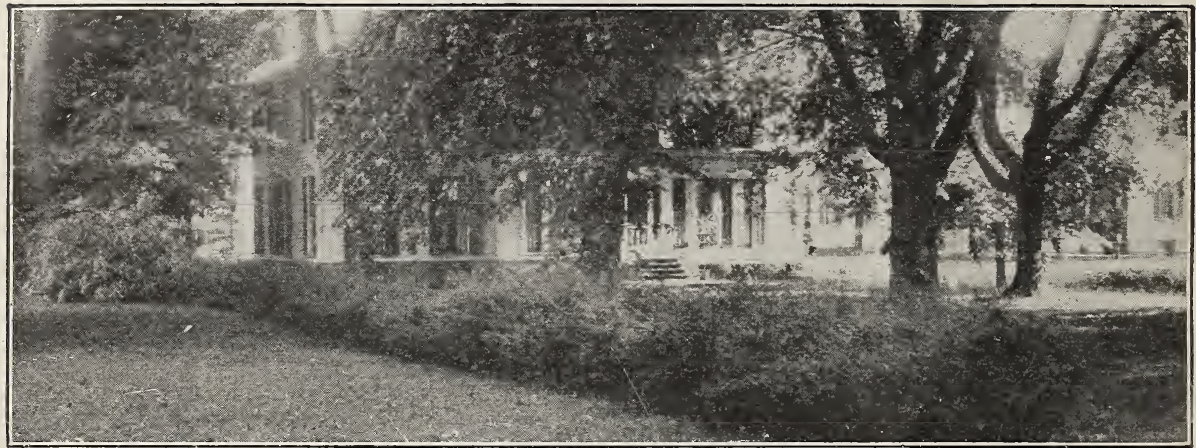

\section{Hardy Deciduous Shrubs}

\section{Ornamental and Flowering}

\section{AZALEA}

Amoena-This little gem is practically ever green. In late Spring the plants are literally smothered with masses of rosy-crimson flowers. Bushy plants, 12 to 15 inches high.

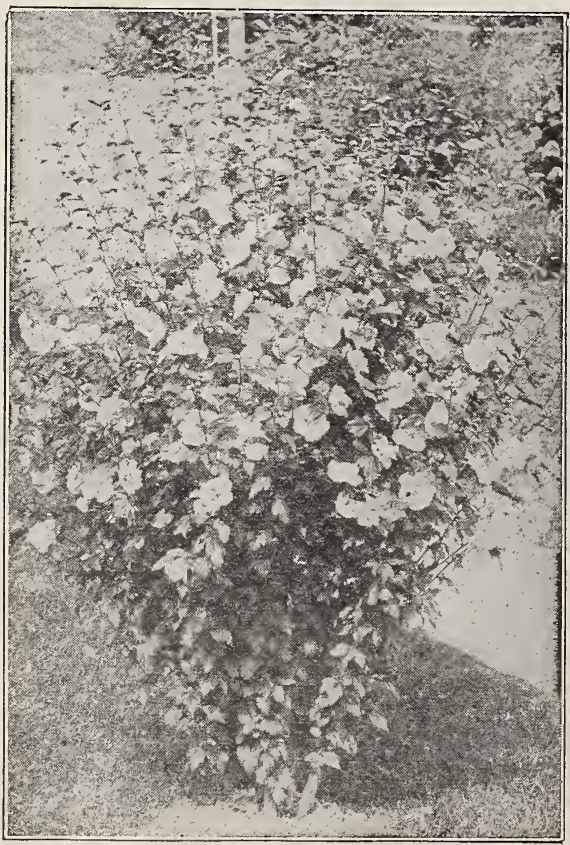

ALTHEA, DOUBLE PINE

\section{ALTHEA OR ROSE OF SHARON (Hibiscus)}

The altheas are free growers, and not particular as to soil. They bloom in August and September, when but few other sorts are in blossom. They attain a height of from six to ten feet.

Double Purple (H. Purpurea fl. pl.).

Double Red (H. Rubra fl. pl.).

Double Pink.

Double White (Alba)-Very large and double, with reddish-purple center.

Variegated Leaved; Double Purple Flowered (Flore Pleno fol. var.) -A conspicuous variety with leaves distinctly marked with light yellow, and having double purple flowers: showy and desirable.

\section{BARBERRY (Berberis)}

Thunberg's (Berberis Thunbergi)-A low, dense, neat little shrub, with a profusion of white flowers in May. These are followed by a heavy crop of rich red berries that cling through the winter. In autumn when both leaves and berries are bright red it is very showy. Valuable for ornamental hedges, masses, borders, etc.

\section{BOX (Buxus)}

The different species vary in size from low bushes to medium-sized trees. All are longlived, of dense, compact growth, and have dark green, glossy leaves. They are used for grouping, edging walks, planting against house foundations for hedges, and in tubs, for formal gardens, terraces and porches. Will grow in sun or shade, but we have found it advisable to use some protection during very severe winters. 


\section{OF N U R S E R Y S TOC K}

\section{CALYCANTHUS FLORIDUS \\ (Or Sweet Scented Shrubs)}

Blooms in June and at intervals through the summer. Flowers of a rare chocolate color; rich foliage. The wood and blossoms have a peculiarly agreeable flavor.

\section{CI.ETHRA ALNIFOLIA}

Sweet Pepper Bush-A pretty little shrub that blooms freely for several weeks in summer; very fragrant white flowers.

\section{DEUTZIA}

The Deutzias are of Japanese origin, extremely hardy, luxuriant foliage, very attractive flowers, and fine habit.

Crenata-Double white flowers tinged with rose. Blooms the middle of June. 5 feet.

Gracilis-A graceful and charming shrub, with pure white flowers. Blooms the middle of June.

Lemoinei-Flowers pure white, borne on stout branches of upright growth. Dwarf and free flowering.

Pride of Rochester-One of the finest varieties. large double white flowers. It excels the older sorts in size of flowers, profuseness of bloom and vigorous habit. Blooms early in June.

\section{DOGWOOD (Cornel or Cornus)}

C. alba-Very conspicuous and ornamental in winter when the bark is blood red.

var. Elegantissima Variegata-One of the finest variegated shrubs; of rapid growth. The leaves are broadly margined with white, while some are entirely white.

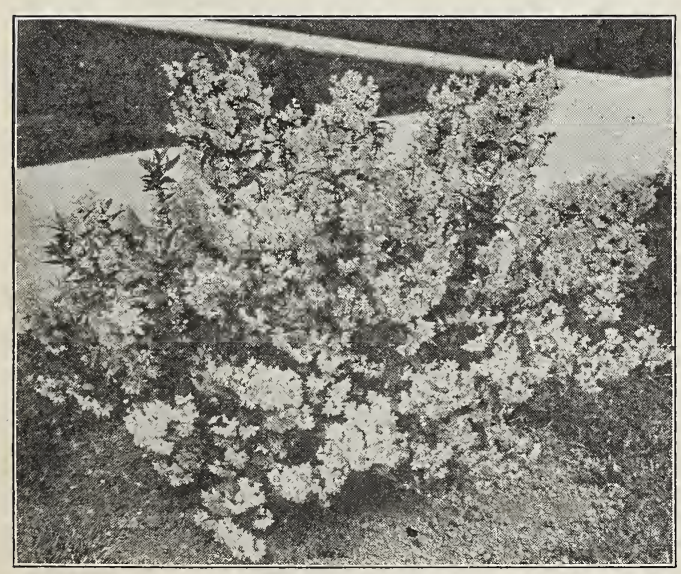

DEUTZIA GRACILIS

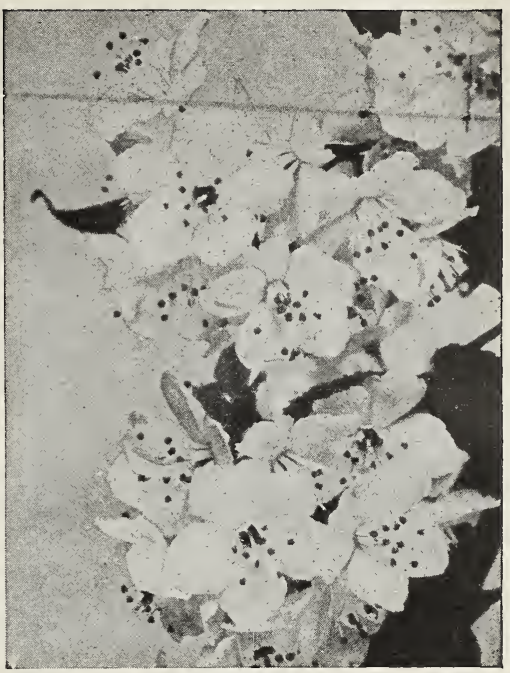

DEUTZIA

var. Sibirica (Red Siberian)-During the winter the bark is of a bright red color. The foliage is beautifully silvery margined.

C. Mascula (Cornelian Cherry)-A small tree, native of Europe, producing clusters of bright yellow flowers early in spring, before the leaves, followed by red berries.

var. variegata (Variegated Cornus)-The flowers are bright yellow and are borne in elusters in early spring, before the leaves appear. The foliage is beautifully variegated with white. Makes a small shrub.

\section{ELDER (Sambucus)}

Hardy, easily grown shrubs.

S. Canadensis (Common Elder) Broad panicles of white flowers in June; reddish purple berries in autumn.

var. aurea (Golden Elder) - A handsome variety, with golden yellow foliage. A valuable plant for shrubberies.

var. laciniata (Cut-leaved Elder)One of the best cut-leaved shrubs.

\section{ELEAGNUS (Oleaster)}

E. argentea (Silver-leaved)-A native species of erect growth and silvery foliage. Flowers small, yellow. July and August.

E. longipes (Japan Oleaster)-In July the plant is covered with red berries. The bush is highly ornamental, the leaves remaining fresh till late in autumn. 


\section{EXOCHORDA}

E. Grandiflora (Pearl Bush)-From North China. A compact, hardy bush 10 to 12 feet high; can be trimmed into any desired shape. The flowers are borne in May in slender racemes of eight to ten florets each.

\section{FORSYTHIA}

F. Fortuneii-Growth upright, foliage deep green, flowers bright yellow. Early flowering shrub. Very hardy.

F. Viridissimi-An elegant, hardy shrub. Bark and foliare a dark green color. Beautiful yellow flowcrs. Blooms in May before the leaves appear.

Intermedia-This also is an erect-growing shrub, but when full grown the branches become arching and it resembles Suspensa; very floriferous.

Suspensa-In this variety we have the weeping form with long, pendulous branches; golden-yellow flowers early in April.

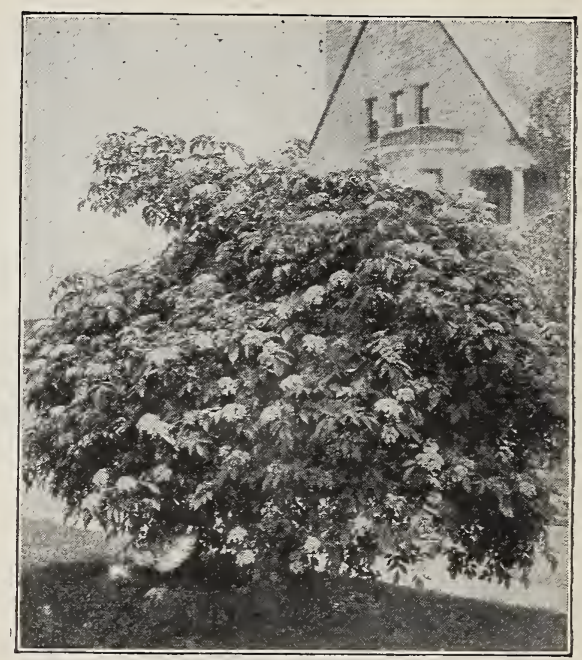

GOLDEN ELDER

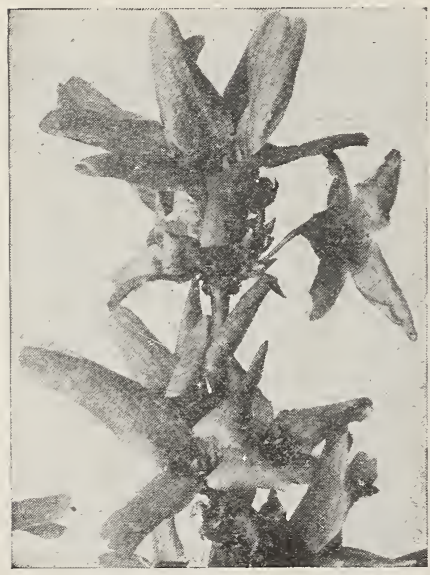

BLOOM OF FORSYTHIA

Morrowi-One of the handsomest of the bush honeysuckles. Wide spreading branches, bush 6 feet. Flowers followed by bright red fruit in August, persisting until late in fall.

Red Tartarian ( $\mathbf{\text { .. }}$ 'Tartarica rubra)-Blooms in May. Bright pink flower

White Tartariau (L. Tartarica alba)-Blooms in May. Flowers a dull white color.

\section{HYPERICUM (St. John's Wort)}

Hypericum (Aureum)-A dense, globular shrub with oval, glossy, foliage and myriads of bright golden-yellow flowers, borne for a period of several weeks.

Purple Fringe, or Smoke Tree (Rhus Cotinus) - A small tree or shrub, very much admired on account of its peculiar bush in mid-summer.

White (C. Virginica) - A superb shrub. 10 to 20 feet. a compact, roundish form, large, glossy leaves, and drooping racemes of pure white flowers. Blossoms in May and June.

\section{HALESIA (Silver Bell)}

Tetraptera-A small native tree, bearing most beautiful bellshaped flowers. similar to the Snowdrop but much larger. Blooms in May.

\section{HONEYSUCKLE}

-desirable variety, with dark almost foliage. flowers. Blooms in May. A valuable shrub.

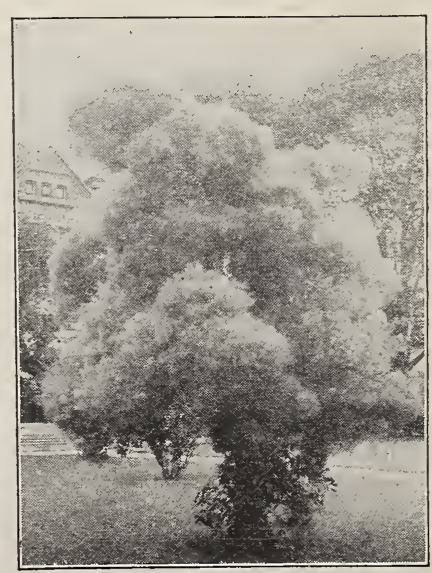

PURPLE FRINGE 


\section{OF N U R S E R Y S T O C K}

\section{HYDRANGEA}

Arborescens grandiflora (Hills of Snow)-The blooms are large, snow white and foliage finely finished. Hardy. Season from June through August. Best Hydrangea.

Paniculata Grandiflora-Hardy; thrives in all soils; grows rapidly and blossoms profusely. The flowers are pure white, afterwards changing to pink.

\section{ILEX (Holly)}

Verticillata (Black Alder, or Winterberry)-Of close, upright growth, with oval foliage; thickly studded in autumn and throughout the winter with masses of most brilliant scarlet berries.

\section{JAPAN QUINCE (Pyrus Japonica)}

C. Japonica-Very ornamental in early spring, as its bright scarlet flowers completely cover the branches before the leaves are formed. Makes a good hedge.

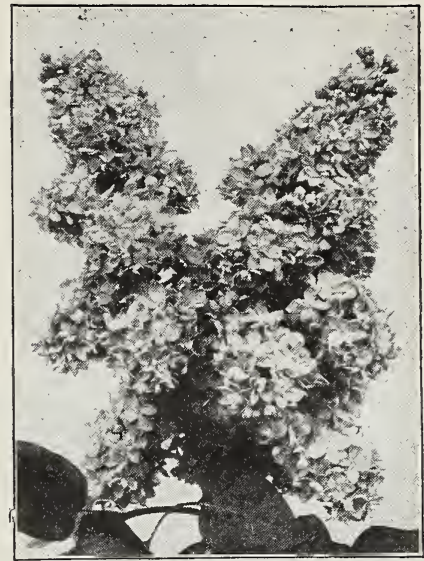

LILAC

\section{KERRIA (Corchorus. Globe Flower)}

Japonica-A beautiful shrub of graceful open habit, with slender green branches clothed with pointed soft green foliage and thickly studded with single, deep golden-yellow flowers in early summer and also borne at intervals in smaller quantities throughout the summer.

Flore Pleno-Double flowering kerria. A medium sized shrub, with double yellow flowers. July to October.

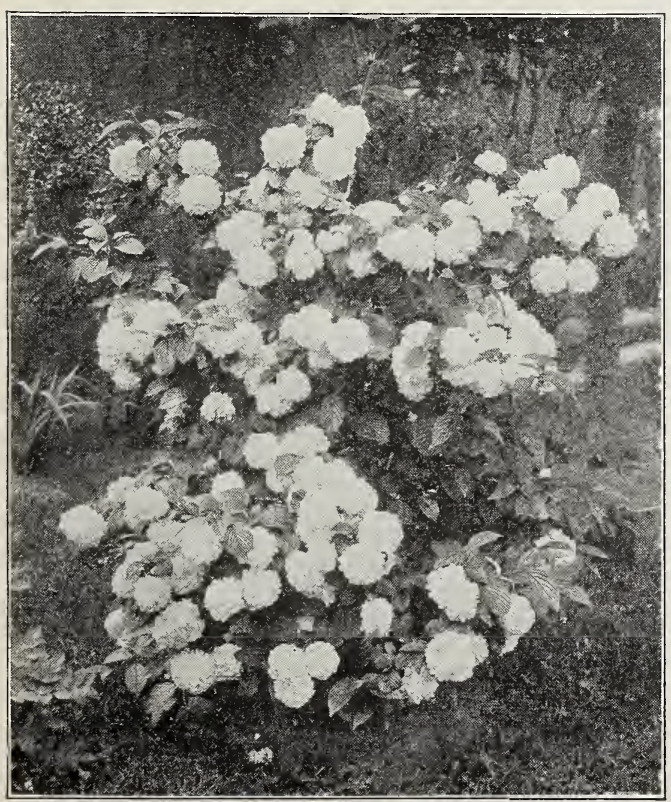

JAPAN SNOWBALL
Ludwig Spaeth-Deep purplish red flowers in dense, large panicles. Best of its color.

Madame Abel Chatenay-Large panicles; double white, very fine.!

Marie Legraye-Large panicles of white flowers. Valuable for forcing. The finest white Lilac.

Madame Lemoine - Superb double white.

President Grevy - Elegant, large. dense trusses of double, deep blue flowers. One of the finest new double sorts.

Persica (Persian Lilac) - Small foliage and bright purple flowers.

Alba (White PersianLilac)-Delicate white fragrant flowers, shaded with purple. A superb variety.

Vulgaris (Common Lilac)-Bluish purple flowers. A standard variety.

Alba (Common White Lilac) Cream colored flowers. 


\section{PRIVET (Ligustrum)}

Chinese Privet (L. Ibota)-A valuable shrub, native of China and Japan. Flowers, large, white, very fragrant, produced in great profusion; leaves long and shining; one of the hardiest of the Privets and distinct.

California (L. ovalifolium) - Of great value as a hedge, and of such positive beauty as to be attractive when grouped with other shrubs. When planted singly it forms a very compact, dense, upright shrub, of medium size. The leaves are so glossy as to have the appearance of having been freshly varnished. The foliage hangs on until late in the winter, making it nearly evergreen.

Ligustrum Amurense (Amoor Privet)(B) A large shrub with upright branches. Leaves dark green and lustrous, tardily deciduous, or in the South nearly evergreen. Flowers white, in erect panicles. Splendid for hedges. Very similar to the California Privet, so universally used for hedging in the east, but unlike it here in that Amur is hardy.

\section{RHODOTYPUS (White Keria)}

Kerroides-A choice and rare Japanese shrub. It is a slender-branched bush, with very pretty, deeply veined leaves, and pure white flowers, $\downarrow$ borne at intervals all summer.

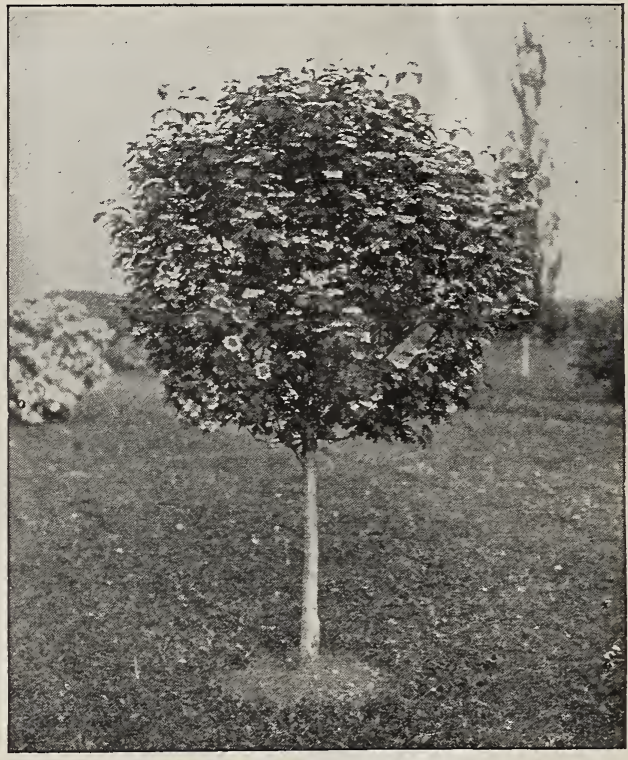

BOGH BUSH CRANBERRY

\section{SNOWBALL (Viburnum)}

Common (Sterilis)-The well-known sort, and a general favorite on account of its large clusters of white flowers in June.

High, or Bush Cranberry (Opulus)-Red berries resembling cranberries.

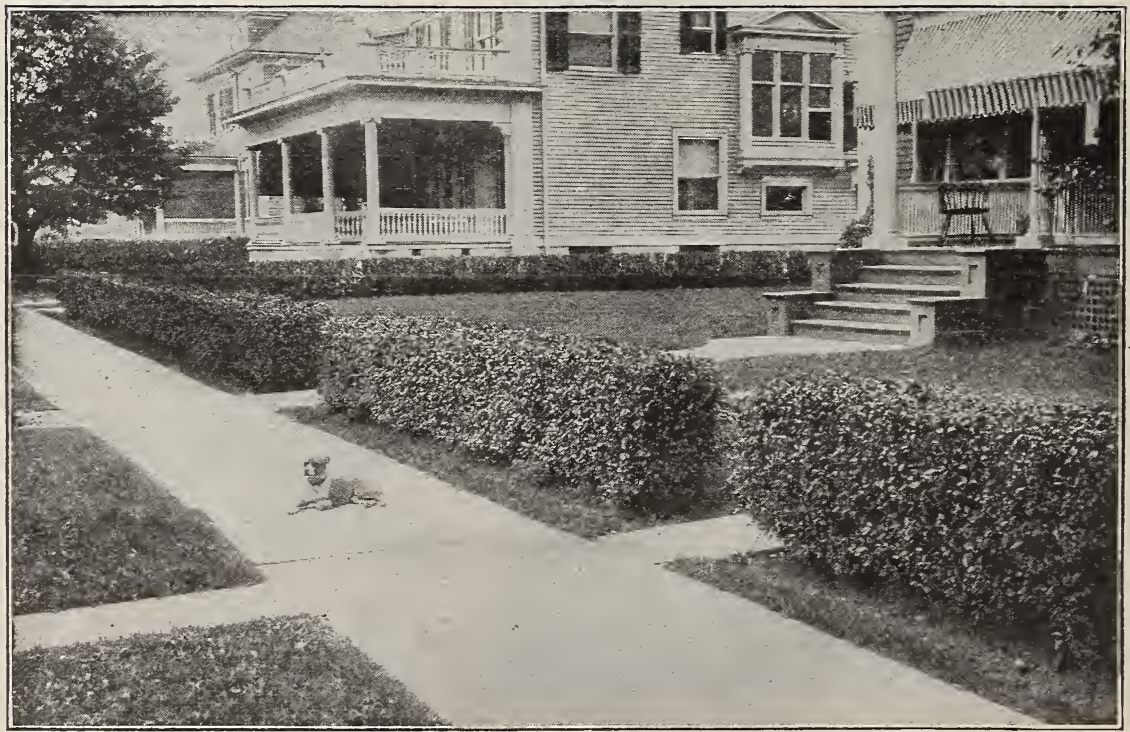




\section{OF N UR S E R Y S T O C K}

Dentatum (Arrow-Wood)-Glossy, handsome leaves, white flowers, and fine, steel-blue berries in fall.

Japan (Plicatum) - A beautiful species from Japan, surpassing the Common Snowball in many respects, as its habit is much better; foliage handsomer, flowers whiter and more delicate.

Tomentosum (Single Japan Snowball)Foliage resembles the Japan Snowball; flowers white, in flat racemes and in great profusion.

\section{SPIREA}

Anthony Waterer-A new dwarf compact-growing shrub. Blossoms in broad flat heads of beautiful deep red color. A perpetual bloomer.

Arguta-One of the finest of early spring blooming shrubs of light open habit of growth, with small deep green foliage of minute purest white flowers.

Aurea-The leaves are bordered with golden yellow, particularly in June, when the branches are covered with small double white flowers.

Billardi-Blooms nearly all summer; rose colored; fine; showy

Callosa Rubra-Desirable because it blooms nearly all summer. The flowers are rose colored, borne in panicles. A very free grower.

Douglas (S. Douglassii)-Spikes of rose colored flowers in July and August.

Golden-Leaved (opulifolia aurea)-Variety with golden yellow foliage, and tinted flowers in June. Strong grower.

Prunifolia (Bridal Wreath)-Beautiful white flowers double and very profuse. Blooms in May. Foliage. scarlet in autumn.

Reovesi-Narrow, pointed leaves. The flowens are white, quite large, and borne in clusters, entirely covering the whole plant. Blooms in June.

\section{STEPHANANDRA}

Flexuosa-A handsome, graceful shrub with spreading, drooping branches and elegant foliage. Bears pure white flowers in June. In Autumn the foliage takes on handsome purptish coloring.

\section{STRAWBERRY OR SPINDLE TREE} (Euonymus)

A showy shrub. Its chief beauty consists in its red berries, hanging in graceful clusters from the end of the branches until midwinter.

\section{SYRINGA OR MOCK ORANGE (Philadelphus)}

Garland ( $\mathrm{Ph}$. Coronarius) - A well known hardy shrub. White, fragrant flowers. Blooms in June. Makes a large shrub.

Golden-Leaved ( $\mathrm{Ph}$. Foliis aureis) - A small shrub of striking beauty. The foliage is golden yellow, and retains its lovely color through the entire season. White flowers. Blooms in June. Very hardy.

Large-Flowered (Grandiflorus)-A desirable sort.

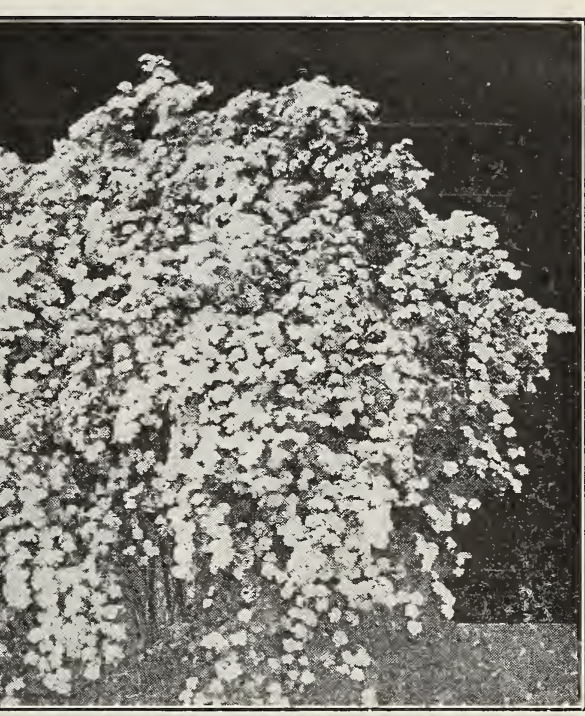

SPIRAE VANHOUTTE

Thunbergs' ('Thunbergii) - A Japanese species of small size, with narrow linear leaves and small white flowers; one of the best.

Van Houttei-The finest of all Spiræas, a most charming and beautiful shrub; having pure white flowers in clusters. Extraordinarily profuse in bloom, and the plant is a vigorous grower and very hardy.

\section{SUMAC (Rhus)}

Copallina (Shining Sumach)-Foliage a lustrous green in Summer, changing to a rich crimson in the Autumn. Greenish yellow flowers in August.

Fern-Leaved (Laciniata)-A hardy plant with beautiful fern like leaves, milky white on under side, changing to a brilliant scarlet in autumn.

Staghorn (R. typhina)-A large shrub or tree, brilliant foliage and scarlet fruit in autumn. 


\section{SYMPHORICARPUS}

\section{St. Peter's Wort or Waxberry)}

Racemosus (Snowberry)-A well known shrub with small, pink flowers and large, white berries that hang on the plant through part of the winter.

Vulgaris-Red fruited or Indian currant. A shrub of very pretty habit. Foliage, flowers and fruit small; fruit purple and hangs all winter.

\section{TAMARIX}

Of great value for planting by the seaside

African (Africana)-Thrives in any soil. The foliage is handsome. The flowers are small, borne in spikes in May. Its habits are upright.

Chinensis-A vigorous upright grower, delicate light green foliage, flowers rose colored, in September.

\section{WEIGELLIA (Diervilla}

Of Japanese origin, producing in June and July superb large trumpet shaped flowers, of various colors.

Candida (white)-It is of vigorous habit, an erect grower becoming in time a large-sized shrub; flowers pure white and produced in great profusion in June; plants continue to bloom during summer.

Rosea-The best known sort. From China. Rose colored, trumpet-shaped flowers. Blooms in June. 4 to 6 feet.

Variegated-Leaved (Foliis variegatis)Leaves bordered with yellowish white, making the bush very conspicuous the entire season. Pink flowers blooming in June.

Eva Rathka-Vigorous growing, and erect in form. The bright carmine flowers are the best of the red flowering kinds.

Floribunda-Of erect habit. Dark redidish purple bloom. A compact slender grower.

\section{Climbing and Trailing Vines}

Ornamentals of this class are so hardy, so easily grown, and so beautiful, that they deserve great attention.

\section{AKEBIA}

Canadensis Quinata-A singular Japanese climbing shrub. with fine foliage, purple flowiers and ornamental fruit.

\section{ARISTOLOCHIA}

\section{(Dutchman's Pipe)}

Sipho-A rapid growing vine with magnificent foliage, ten to twelve inches in diameter, and curious pipe-shaped, yellowishbrown flowers.

\section{BIGNONIA (Trumpet Flower)}

Radicans-A vigorous and hardy climber, with clusters of scarlet, trumpet-shaped flowers in August.

Grandiflora (New)-Leaves thick and shining, and immense blossoms of gorgeous crimson and yellow.

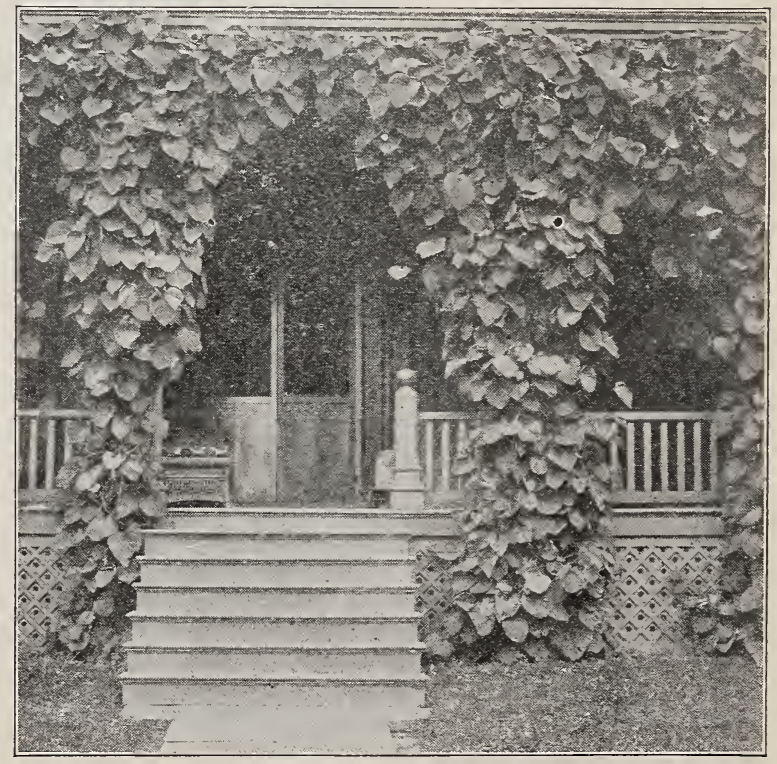

ARISTOLOCHIA

\section{CINNAMON VINE}

(Dioscorea)

D. divaricata (Chinese Potato or Yam)Very tall climber, roots very deep. A tropical plant but hardy here.
Scandens (Bitter Sweet)-One of our native climbing plants of rapid growth, with attractive light green foliage and yellow flowers during June, which are followed in the Autumn with bright orange fruit. 


\begin{tabular}{llllllll}
\hline OF & N UR S E R Y S O K & 31 \\
\hline
\end{tabular}

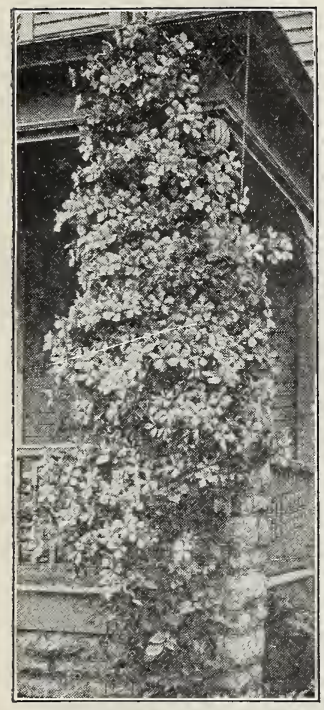

CLEMATIS JACKMANNI

\section{CLEMATIS}

The finer varieties of clematis are today the most showy and effective of all the hardy flowering climbing vines known, so far as richness of color and elegance of form of the flower is concerned. They are peculiarly adapted for covering pillars, trellises, walls, fences rocks, etc., their exceedingly rapid growth rendering them especially valuable for hiding from view any unsightly object. They are equally efficient when used as a bedding plant, covering a bed very quickly if pegged down occasionally.

C. coccinea-A bell shaped heavy petaled flower, borne in profusion for a long season, color bright scarlet.

C. Duchess of EdinburghThe best of the double pure whites. Deliciously scented.

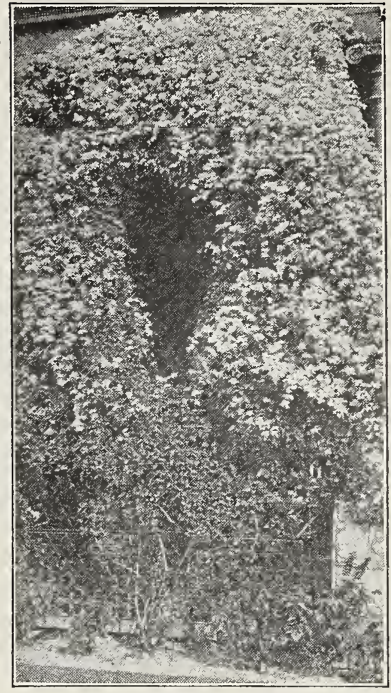

CLEMATIS PANICULATA

C. Crispa-Flowers blue, with center of petals an opaque white; fragrant.

C. Henryii-Fine bloomer; flowers large, of a beautiful creamy white, consisting generally of from six to eight sepals. June to October.

C. Jackmannii-One of the most popular varieties. It is a strong grower and produces a mass of intense violet purple flowers from June to October.

C. Madame Eduard Andre-Flowers large, of a beautiful bright velvety red, very free flowering and continuous bloomer.

C. Paniculata-From Japan. A luxuriant grower, profuse bloomer with fine foliage. Flowers of medium size and fragrant, produced in the greatest profusion in late summer.

C. Ramona-A strong, rampant grower, and very hardy. It is a free and perpetual blooming variety; the color of the flower is a deep sky blue, and larger than any variety.

\section{EUONYMOUS}

E. Marginata alba (Variegated Leaved Euonymous)-Silver striped and edged with silver; a beautiful evergreen plant; slow grower; valuable for edging borders.

E. Radicans. - Foliage green, edged with silver. More hardy than the preceding.

\section{HONEYSUCKLE (Lonicera)}

Chinese Twining (L. Japonica)-A welknown vine holding its foliage nearly all winter. Blooms in July and September and is very sweet.

Hall's Japan (Halleana) - An almost evergreen variety, with pure white flowers, changing to yellow: very fragrant and a vigorous grower. Covered with flowers from July to December.

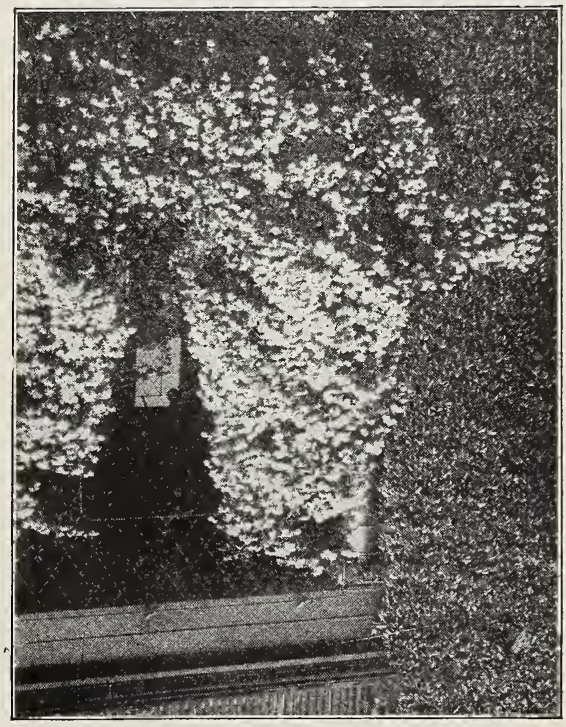

CLEMATIS AND AMPELOPSIS 


\section{CLIMBING VINES-Continued}

Monthly Fragrant (Belgica) Flowers red and pale yellow; sweet scented; blooms through the summer.

Scarlet Trumpet Monthly (Sempervirens)-Flowers deep red, trumpet shaped, flowers all Summer.

\section{IVY (Hedera)}

American Ivy, or Virginia Creeper (A. quinquefolia)Also called Woodbine. A very rapid grower. having beautiful, dark green foliage; assumes rich crimson hues in autumn.

Englemanni-Very similar to Quinquefolia, clings closely to its support, and is a valuable vine for covering walls and trellises.

English (H. Helix) - A well known old and popular sort.

Veitchii, or Boston IvyLeaves overlapping each other they form a dense sheet of green. The plant requires a little protection the first winter until it is establisher but after that it may be

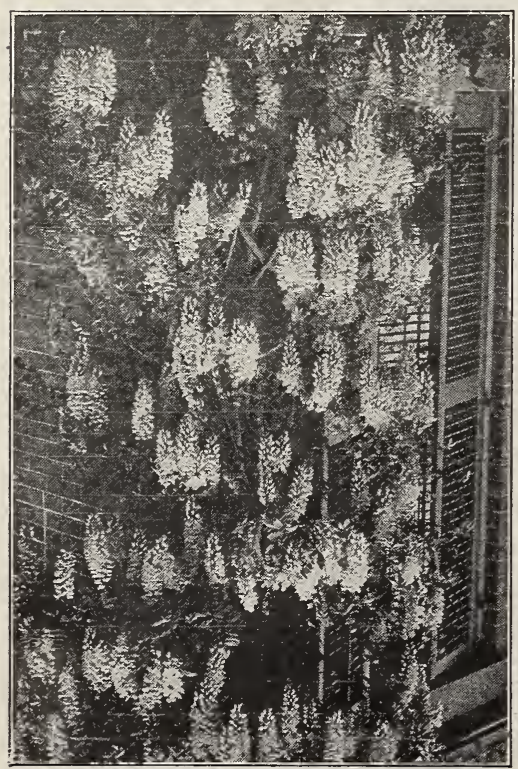

CHINESE PURPLE WISTARIA

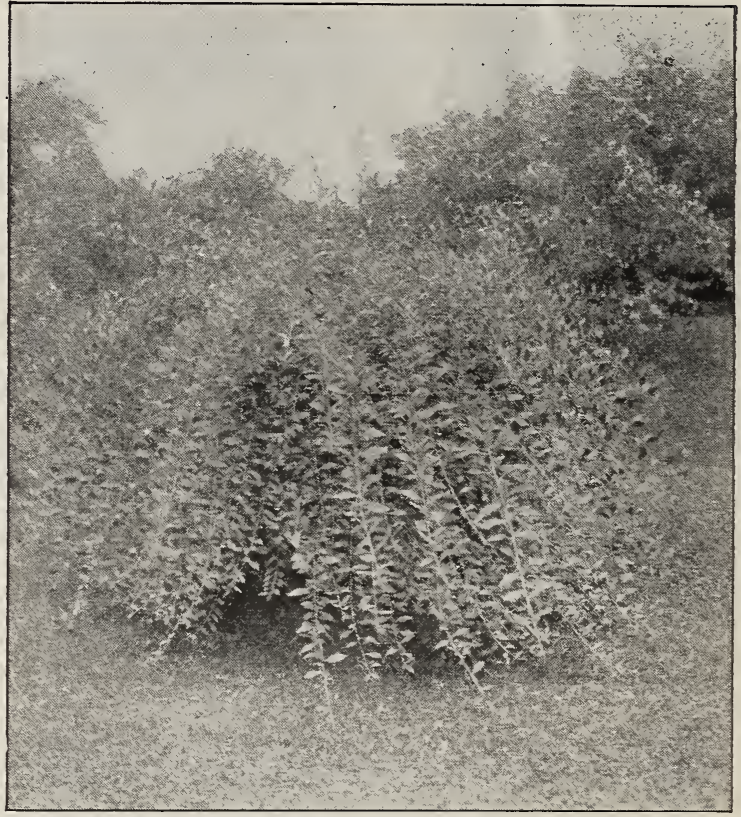

MATRIMONY VINE

safely left to care for itself. It grows rapidly and clings to the surface of even a painted brick wall with great tenacity. The foliage changes to crimson scarlet in autumn.

\section{MATRIMONY VINE \\ (Lycium Sinensis)}

A vigorous climber, covered with bright purple, star shaped flowers, succeeded by brilliant scarlet berries. Flowers and fruit continue forming throughout summer. Of the easiest culture, thrives everywhere and in any soil.

\section{TRUMPET VINE (Radicans)}

A splendid climber, vigorous and hardy, with clusters of large, trumpet shaped scarlet flowers in August.

\section{WISTARIA}

Chinese Purple (W. sinensis)-One of the most elegant of climbing vines and a rapid grower. Bears long clusters of pale blue flowers in May and June, and also in September. Extremely hardy.

Chinese White (W. var. c. alba)-Habit of growth similar to Chinese Purple, but the flowers are somewhat smaller and pure, white. Blooms in June and September. 


\section{Hardy Herbaceous Perennials}

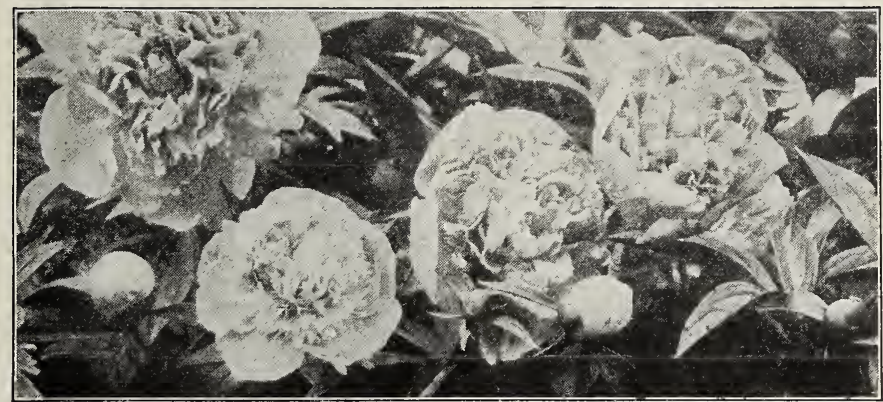

These are plants which may be left permanently in the open ground. Their foliage dies down each 'fall, and the roots send out new growth each spring.

With an assortment of these plants, it is very simple and easy to secure a beautiful collection of flowers, varying in color and season of bloom to suit the fancy of the gardener.The Perennials offered here may be planted either fall or spring.

\section{ADAM'S NEEDLE (Yucca)}

Filamentosa-Of tropical appearance with large sword-like foliage and upright branched spikes of fragrant creamy-white flowers. 4 to 6 feet. June and July.

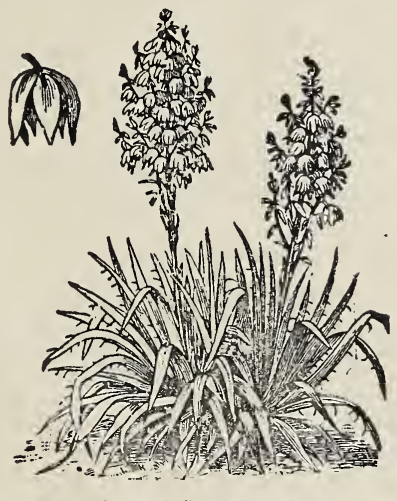

ADAM'S NEEDLE

\section{ACHILLEA (Yarrow)}

Achillea millefolium rubrum-A garden form of the "white Yarrow" so common along the roadsides. Deep rose; flowers freely.

A. Ptarmica plena-"The Pearl." Pure white double, particularly good for cutting.

A. tomentosa-A golden species, very different from all the preceding, growing in tufts and covering the ground with a carpet of green. 2 feet. June to September.

\section{ACONITUM (Monkshood)}

Aconitum Napellus-A stately plant so often seen in old fashioned gardens. Large dark purple flowers. September and October.

Aconitum Autumnale-A tall plant. With spikes of showy, blue, helmet shaped flowers. 3 to 4 feet. August, September.

\section{ANEMONE (Wildflower)}

The Japanese Anemones are undoubtedly the best of their kind, and well worth special attention. They bloom in late fall when flowers are becoming scarce, and are very fine for cutting.

Anemone Japonica-There are a number of forms and colors of the Japanese anemones all of which are particularly fine. We list the following as being the best of the class.

A. Japonica alba-Large white flowers.

A. Japonica brilliant-Beautiful shade of dark red.

A. Japonica, Queen Charlotte-Beautiful new variety, with large, semi-double fowers of exquisite pink.

\section{ANTHEMIS (Marguerite)}

Tinctoria-A profuse bloomer and very showy. Lemon-yellow color. A good border plant. 2 feet. June to September.

Tinctoria Alba-One of the most satisfactory Creamy white flowers. 2 feet. June to October.

Kelwayi-Flowers very deep yellow, fine for cutting. 2 feet. June, October. 


\section{G E N E R A C A T A L O C}

\section{AQUILEGIA (Columbine)}

The Columbines have an established place in all old fashioned gardens. Their curious forms and many pleasing shades of color, and the readiness with which they adapt themselves to all localities have made them prime favorites.

A. Alpina-In many shades of blue and purple. June.

A. Canadensis-Scarlet. May and June. $1 \mathrm{ft}$. A pretty flower for rockwork and partially shaded places.

A. Vulgaris-Common garden Columbine, in all shades of blue and purple.

\section{ASTER (Michaelmas Daisy or Starwort)}

In the fall of the year, they make a grand sight when planted in masses, and if the right selection be planted, will keep the garden gay from June until frost.

A. Amethystinus-One of the most showy. Large, pale blue flowers. September.

A. Chapmani-White.

A. Incisus-Light blue. July and August

A. Tataricus-Has a stem 6 to $8 \mathrm{ft}$. high, with a huge panicle of light purple flowers, in the fall, after almost all other flowers are over.

\section{BUTTERFLY BUSH (Buddleya)}

Veitchii-Long graceful stems bearing beautiful lilac colored clusters of miniature flowers. 4 to 5 feet. July to frost.

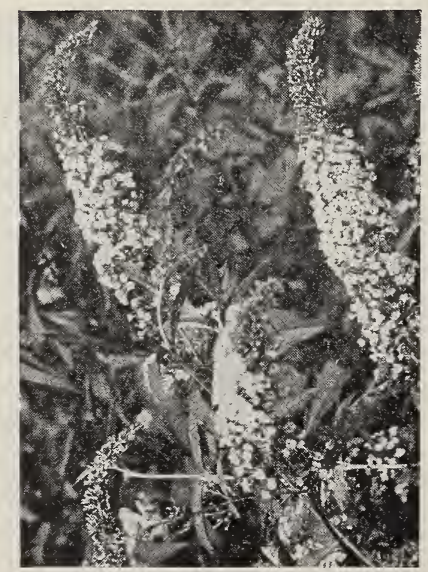

BLOOM OF BUTTERFLY BUSH

\section{CAMPANULA (Bellflower or Bluebells)}

C. glomerata-Blossoms borne in clusters on long stems. June. Blue. $11 / 2 \mathrm{ft}$.

C. medium-The well knowi Canterbury Bell. Flowers large. Blue and white. $2 \mathrm{ft}$.

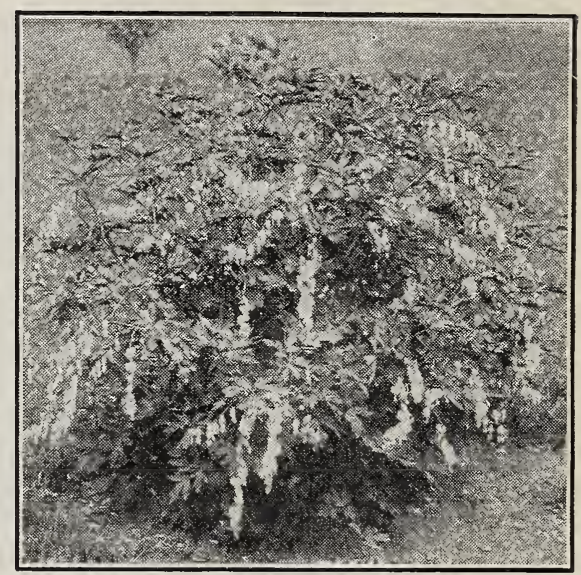

BLEEDING HEART

C. persicifolia alba-White flowers of immense size. 2 feet. June, July.

C. rotundifolia (the Scotch Harebell)-A pretty plant, well deserving of its popularity. 1 foot. June, August.

\section{CHRYSANTHEMUMS}

Our collection of hardy chiysanthemums is of the finest, the following being a choice selection of the best in size and color.

Autumn Beauty-Golden brown.

Eva-Clear pink.

Favorite-Bright pink.

Gold Queen-Clear yellow.

India-Indian Red.

Klondike-Deep brilliant yellow.

Minta-Iight pink.

Queen of Whites-Creamy white.

Rosea-Bright red.

Snowclad-Pure white.

\section{CONVALLARIA (Lily-of-the-Valley)}

There is a corner in every garden where a few of these old favorites should be planted. Our stock is well established and will give good satisfaction.

Convallaria majalis-The well known Lily of the Valley.

\section{DAISY SHASTA (Alaska)}

A wonderful plant of the Daisy family, producing an abundance of beautiful white flowers. From $t w$ w to five hundred blossoms in the season is the remarkable record.

\section{DELPHINIUM (Hardy Larkspur)}

The following list of Delphiniums comprises the best in general cultivation. They bloom from June to August.

D. Azureum-A beautiful azure blue, varying to white. 


\section{OF $\quad$ N U R S E R Y S T O C K}

\section{DELPHINIUM (Cont.)}

Belladonna-Everblooming; skyblue color; divarf growing; flowers till frost. 2 feet.

Chinense-Low growing, with gentian-blue flowers.

Formosum-Dark blue with white center; very hardy and free flowering.

Gold Medal-Strong vigorous habit with flowers on spikes two feet long or more Flowers light shades of blue.

\section{DIANTHUS (Pinks)}

D. Barbatus-The well-known Sweet William, in many colors. Blooms continuously all summer, and is one of the easiest to cultivate.

D. Heddewigi-Among the most beautiful of the hardy pinks. Flowers of all colors and many peculiar markings.

D. Chinensis-Beautiful single and double flowers of many colors and markings.

\section{DICENTRA (Bleeding Heart)}

D. Spectabilis-A pleasing and well-known plant. It can hardly be surpassed for cutting for vases. Pink. Early spring.

\section{DIGITALIS (Foxglove)}

The Digitalis likes a little shade or a cool, somewhat moist place, though doing well under generally fair conditions.

D, grandiflora-Yellow flowers; quite rare. June and July.

D. purpurea-Flowers purple and white. May and June.

D. lanata-Small flowers, creamy yellow varying to white and pale lilac; racemcs long and dense.

\section{FUNKIA (Day Lily)}

The day lilies are very attractive, both in flowers and foliage, and thrive well in damp and partially shaded places, although they will grow in almost any locality.

F. Japonica (subcordata, oralba) - Pale green foliage and large, fragrant, pure white, wax-like flowers. One of the best. September.

F. Lancifolia-Dark, shining green, narrow foliage and blue flowers. August.

\section{GAILLARDIA (Blanket Flower)}

No plant in the hardy garden gives more satisfaction than the Gaillardia. It flowers in great profusion nearly all summer long. The long, dry spells affect it very little, and except in very wet places, it will grow anywhere.

Gaillardi arista-Newest hybrids, very large and fine. Crimson, yellow and brown are the prevailing colors. Its value is heightened by removing the old flower-heads, thereby lengthening the blooming period.

G. Maxima grandiflora-Extremely large flowers of bright golden yellow. In bloom constantly from early summer to frost.

\section{HEMEROCALLIS (Yellow Day Lily)}

The Hemerocallis, or bronze and yellow day lillies are among the most popular of hardy plants. All are robust growers and satisfactory in every way.

II. flava-Lemon-vellow. Very fragrant and one of the best. June.

H. fulva-The old-fashioned bronze day lily. August.

\section{HOLLYHOCK (Althea Rosea)}

The stately hollyhock is more popular than ever, although it is perhaps one of the oldest of garden plants. The doubles are in six colors, the very best strains of white, red, vellow, maroon, salmon and pink; singles mixer.

\section{IRIS}

Beautiful flowering, hardy bulbous plants which bloom early in the spring.

Aurea-Solid, bright yellow; very fine.

Madame Chereau-White, elegantly frilled with violet. One of the best. Very effective for edging.

Pallida Prosperden-Light and deep lilac.

Queen of May-Light lilac, blending to white.

\section{MYOSOTIS (Forget-me-not)}

Myosotis palustris-The old fashioned forget-me-not. Dainty blue.

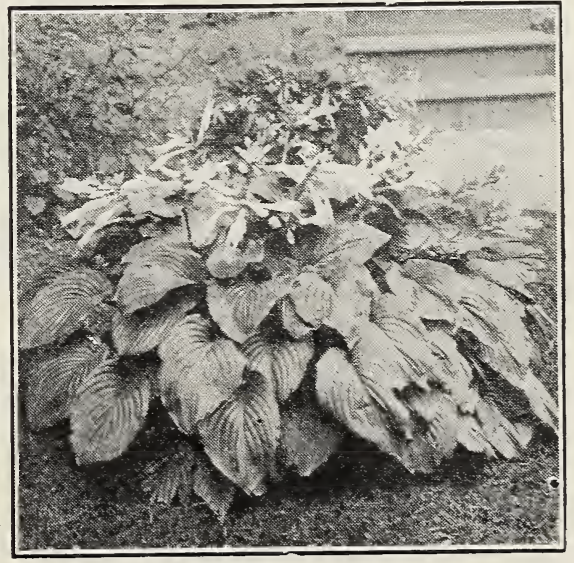

WHITE DAY IIIY 


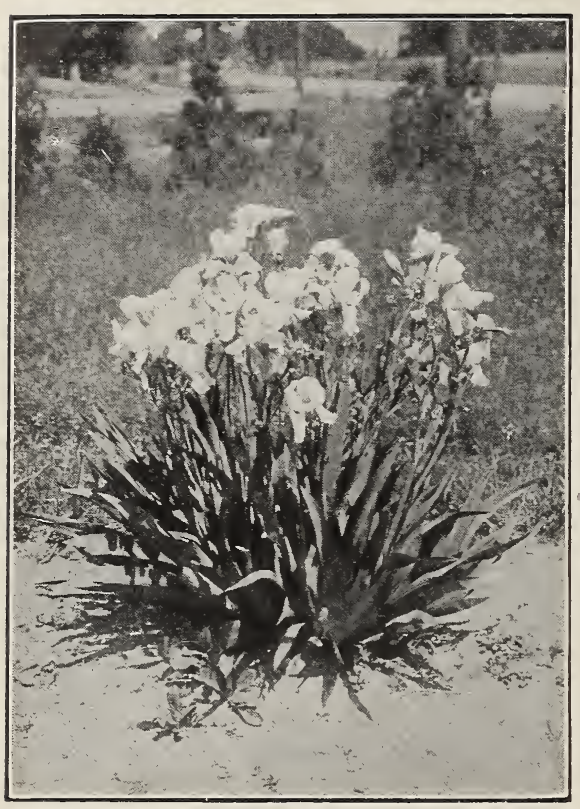

IRIS

\section{OENOTHERA (Evening Primrose)}

Oenothera Missouriensis (macrocarpa)Lemon yellow; very large flowers and curious fruit.

M. speciosa-Large white flowers. A grand species of exceptional merit.

M. Youngii-Pale yellow.

\section{PAEONIES (Herbaceous)}

It is surprising that so noble a flower, almost rivaling the Rose in brilliancy of color and perfection of bloom, should be so neglected. Amateurs seem to have lost sight of the many improved varieties introduced within the last few years, and our finest gardens, perfect in other respects, are singularly deficient in specimens of the newer kinds. They blossom early in June. Our collection has been made with great care and includes the best and most distinct varieties.

Alba Superba-White, large and full, touched with carmine.

Baron Rothschild-Outside petals rose, salmon center, sweet, distinct.

Caroline Mather-Purple crimson, very large, double and very dark.

Couronne d'Or-Snowy white with crimson blotches in center.
Duchess de Nemours-Pıre white Crown sulphur white collar. Fragrant, early.

Duke of Wellington-White sulphur center.

Edulis Superba-Soft pink, profuse, early.

Elegans-Dark pink, salmon center, loose fine, very fragrant.

Festiva-White, outside petals shell pink.

Festiva Maxima-Creamy white with small center of carmine; round, early, sweet.

Francois Ortegat-Purplish crimson with brilliant golderı yellow antlers.

Humei-Large, full rose color flowers; late, one of the best.

La France-Pink outside petals with yellowish center. Very fine.

La Sublime-Crimson, fragrant, very fine full flowers.

Louis Van Houtte-A fine dark cherry red; very double.

Mme. Crousse-One of the best whites.

Officinalis Rubra-Crimson, large, very early.

Rosea Grandiflora-Rosy crimson, very double, early.

Triumph du Nord - Violet rose, lilac shade.

Queen Victoria (Whitleyii)-Pure white, one of the best standard varieties for cut flowers.

Victor Lemans-Rosy outside, white center, spotted with carmine.

\section{PAPAVER (Poppy)}

Papaver bracteatum-Crimson scarlet, with black spots.

P. nudicaule (Iceland Poppy)-D warf form; bright yellow flowers.

P. orientale-Large, bright crimson. June.

\section{PHLOX}

It is no exaggeration to say that the perennial phlox are among the best and most popular garden plants. For producing a grand show of color thay have no equal; they produce a fine effect when grouped with other plants in the hardy border, furnishing brightness after the shrubs are done blooming.

Another good quality is it begins to blossom in early summer and continues until late in the fall.

Amazon-Large pure white flowers.

Boule de Feu-Brilliant scarlet; dwarf.

Flambeau-Bright orange red, dark center.

Fraulein G. Von Lassburg-Pure white.

Isabey-Beautiful salmon pink. 
L'Esperance Lavender pink, white center. Pantheon-Large salmon pink flowers Pecheur d'Island Pure white, large, early. R. P. Struthers-Brilliant red.

Richard Wallace-White, violet center. Sunset-Dark rosy-pink.

Wm. Robinson-Salmon rose, pink center.

\section{PLATYCODON (Chinese Bellflower)}

Handsome flowers, with a flowering season lasting from June to October. The prevailing color is blue, but they often come white or variegated.

Platycodon grandiflorum-The tallest, growing 2 feet high.

P. Japonicum-More bushy, with larger flowers.

\section{RUDBECKIA (Cone-flower)}

The Rudbeckias do much to keep the garden bright during the hot days of 'summer. All are of a rich yellow color, and, with one exception, have conc-shaped, brown centers.

Rudbeckia fulgida hirta and speciosa are kinds known as Black-eyed Susans, differing only in habit. They produce sheets of golden bloom in July and August.

R. lanciniata (Golden Glow) - The double yellow, dahlia-like flowers borne on stems 6 to 8 feet high, in great profusion, makes it a very conspicuous object during August. sending up flower-stems 5 feet high, each stem bearing from one to four flowers.

\section{SOLIDAGO (Goldenrod)}

Although these are so common, they make very pleasing subjects to plant along shrubbery borders.

Solidago caesia-One of the finest of the goldenrods.

\section{STOKESIA}

Stokesia cyanea-A very pleasing flower, very much like the China Aster. Blue. July to September.

\section{TRITOMA (Red-hot-Poker Plant)}

Has sword-like leaves and dense spikes of fiery red flowers, borne on a stiff stem, 3 to 4 feet high. Needs protection in winter.

Tritoma uvaria grandiflora-Vermillionscarlet flowers changing to orange. July and August.

\section{TROLLIUS (Globe Flower)}

The Trollius, or Globe flowers, are very attractive, and much resemble large buttercups.

Trollius Europaeus-Yellow. Large. May and June.

R. Maxima-Very distinct and striking, having large, glaucous green leaves, and

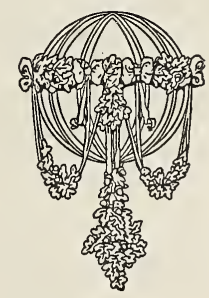




\section{Hardy Rose Bushes}

\section{Cultural}

Roses succeed best in a deep, rich, clay loam soil. In making a rose bed, prepare the soil as follows: If in the lawn, and the ground is sodded over, remove the sod, if the ground is a stiff clay, to the depth of four inches, spade up the ground to the depth of 15 inches thoroughly then prepare a compost as follows: Two parts of leaf mold, one part sandy soil, or leached ashes, one part good, well-rotted cow manure. Mix these thoroughly together and place six inches deep of this mixture on top of the bed. Spade it in thoroughly, mixing into the ground. If the ground is sandy use the same amount of clay loam and cow manure. If it is a clay loam use leaf mold two parts, and cow manure one part, and proceed the same as above; if it is a muck and the ground is well drained, use a liberal amount of well-rotted cow or horse manure. The manure must be well rotted and mixed thoroughly through the soil.

How to Plant-Place new stock in soft water twenty-four hours before setting; prune off all the broken roots. Plant $2 \frac{1}{2}$ feet apart. If set in rose beds 2 feet; in hedge, if set two rows side by side, $21 / 2$ by $31 \%$ feet. When setting be careful to straighten out the roots and press the dirt well around them with foot or hands. Set them as deep as they grow in the nursery.

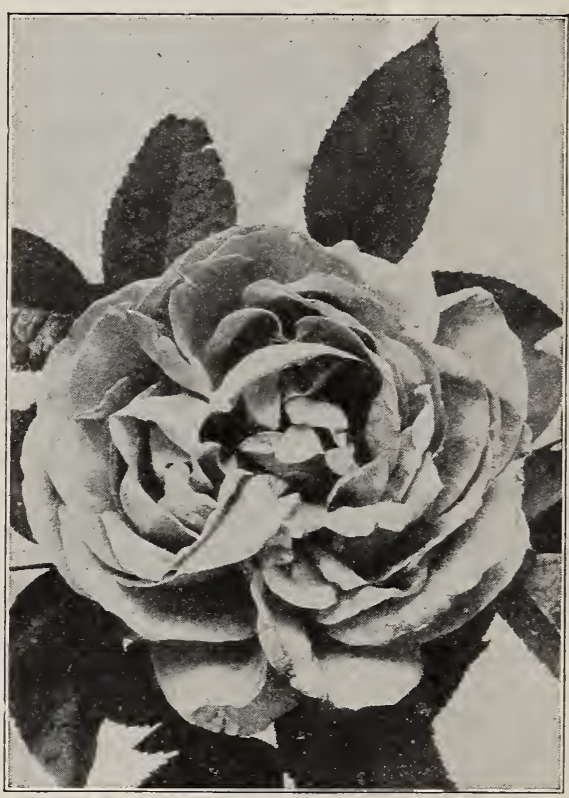

ANNE DIESBACH You can tell by the dark earth-line on the rose stalk. Budded roses should be set with the bud 4 inches under the ground. After setting, cut the tops off the weak plants 6 inches from the ground, and the strong plants 8 inches, either fall or spring setting. If it is in the spring cover the top of the bed $11 / 2$ inches deep with good rotted manure. If it is a fall set, after cutting the tops off, hoe the dirt up around the stalk three or four inches, and before cold weather sets in, or about the time, hoe the dirt around them clear up to the top, and press around the plants, then cover three or four inches deep with good horse manure from the stable, which should have plenty of straw in it; leave this on all winter. When spring comes in March or April, owing to the earliness of the spring, remove all the manure and level up your bed; put two inches of this manure on top of your rose bed, shaking out all the straw; dig this into the ground with manure fork.

\section{HYBRID PERPETUAL VARIETIES}

Alfred Colomb-Bright carmine red; clear color, large, deeply built form; exceedingly fine.

American Beauty-The flowers are a deep crimson color of very large size, and the most fragrant of its class. It is a continuous bloomer. Should be protected in winter.

Anne de Diesbach-Brilliant, crimson, sometimes shaded with bright maroon. A superb garden sort; fragrant; one of the hardiest and best.
Baronne de Bonstetten-Rich, dark red, passing to velvety maroon, highly fragrant. Very double.

Baroness Rothschild-Light pink, cupped form, very symmetrical, without fragrance, very beautiful. A moderate grower only.

Coquette des Alpes-Stronger in growth and larger in flower than any of the other Hybrid Noiesttes. The blooms are of medium size, white slightly tinted with rose on the edge of the petals. 


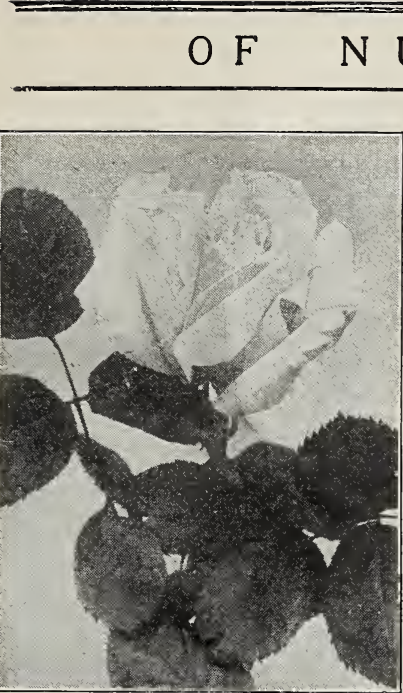

FRAU KARL

Captain Hayward-Bright crimson carmine, an entirely distinct shade of color. Flowers of perfect form, and very sweet.

Clio-The flower is perfection in form, with fine broad petals; color delicate satiny blush, with a light shading of rosy-pink at the center.

Eugenie Verdier-Beautiful silvery pink, tinged with fawn; large, full, finely formed; exquisite buds.

Fisher Holmes-Deep, glowing crimson; large, moderately full, and of fine imbricated form. A superb rose.

Francois Levet-Cherry red; medium size, well-formed; very free bloomer.

Frau Karl Drusckhi - This new hardy Rose is of recent origin, and has won many prizes and made many friends. It is unquestionably the ideal hardy white rose. Its flowers, which are very large. are perfect in form and snowwhite in color, with large shell-shaped petals, forming a beautiful flower.

General Jacqueminot--Brilliant crimson, large and very Gne, one of the handsomest and most showy roses of this color. Beautiful in the bud; semi-double when full blown. Of fine growth free; a universal favorite.

Harrison's Yellow (Austrian)-Bright yellow.

Hugh Dickson (New)-Intense brilliant crimson shaded scarlet, with large, smooth petals, slightly cupped. Vigorous growth.

John Hopper--Rose, with rosy crimson center; splendid form. Standard sort.

Jules Margottin-Light, brilliant crimson; large, full and beautiful.

Lady Helen Stewart-Bright crimson scarlet; large, full and of perfect form, produced on long, stiff stems, highly perfumed.

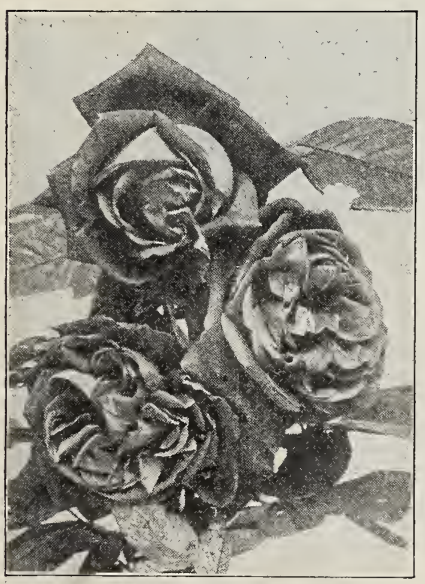

M. P. WILDER
La France-Delicate silvery rose; very large and full an almost constant bloomer; a moderate grower; semihardy.

Louis Van Houtte-Beautiful maroon; medium size; full of fine shape; deliciously perfumed.

Madam Caroline Testout-Silvery rose, flowers large, double.

Mabel Morrison-White, sometimes tinged with blush; in the Autumn the edges of the petals are often pink.

Madame Gabriel Luizet-A magnificent pink rose; very large, and possesses a pleasing fragrance. Known as Hardy LaFrance which it resembles.

Madame Plantier (Hybrid China)-Pure white, above medium size. One of the best white roses for hedges and for massing in groups.

Magna Charta-Bright, pink, suffused, with carmine: very large, full and fragrant with magnificent foliage. A free bloomer. 
Marchioness of Londonderry-A new white rose. Flowers of great size, perfectly formed on stout stems. Color ivory white; free blooming; perfumed.

Margaret Dickson-Of magnificent form; white, with pale flesh center; petals very large, shell shaped, and of great substance; fragrant, a fine variety; foliage very large, dark green.
Marshall P. Wilder-Cherry carmine; continues in bloom long after other varieties are out of flower; the finest H. P. rose yet produced.

Mrs. John Laing-Soft pink; large and of fine form, produced on strong stems; exceedingly fragrant; one of the most valuable varieties for forcing, and flowers continuously in the open ground. The most beautiful rose of recent introduction.

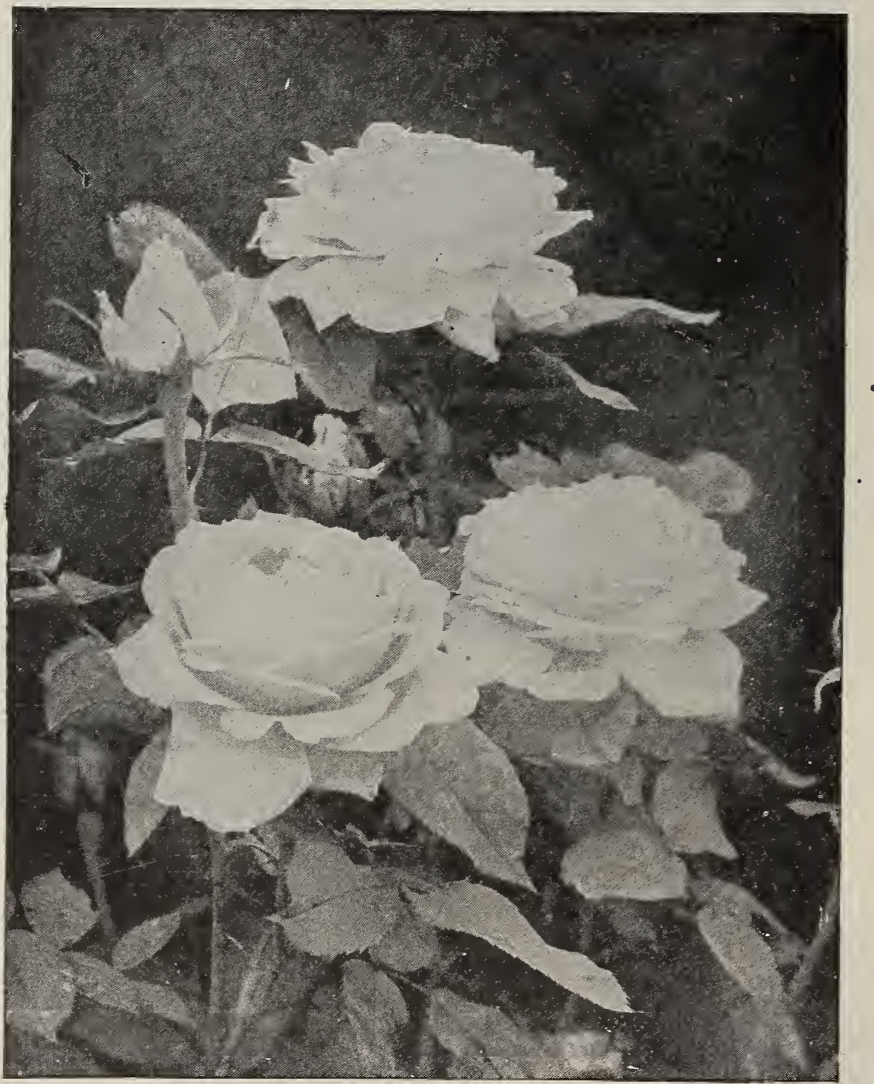

MADAM GABRIEL LUIZET

Paul Neyron-Deep rose color; good foliage; by far the largest variety in cultivation.

Persian Yellow (Austrian)-Deep golden yellow; double and fine.

Pierre Notting-Deep velvety crimson. A beautiful globular-shaped flower, distinct and fine.

Prince Camille de Rohan-Deep velvety crimson; large, moderately full. A splendid rose.
Soleil D'Or (Golden Sun)-The fiowers are large, full and globular, fragrant; buds conical shaped; color superb, varying from gold and orange-yellow to reddish-gold, shaded with nasturtium red.

Ulrich Brunner-Brilliant cherry red, a very effective color; flowers of fine form and finish, carried well upon the plant; petals of great substance; plant vigorous, hardy and resists mildew. One of the best varieties for forcing and open air culture. 


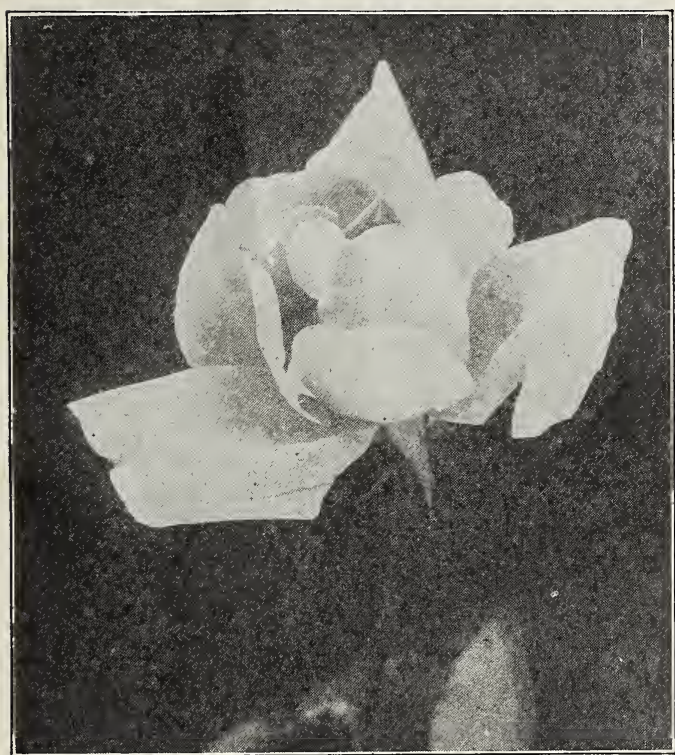

MADAM CAROLINE TESTOUT
Jonkheer, J. L. Mock-Carmine changing to imperial pink. A novelty of distinct merit.

Juliet-Outside of petals old gold, i nterior rich rosy red, changing to deep rose as the flowers expand. Flowers rather large, very double, fairly fragrant.

Kaiserin Augusta Victoria-A superb white Rose, faintly tinted with cream and lemon-yellow. Large, full and double; their fragrance is peculiarly rich and delightful.

Killarney-Its color is a sparkling, brilliant pink. The blooms are large, the buds long and pointed; a Rose of unusual excellence.

Killarney White-Pure white, delicate appearance, very fine form.

Lady Hillingdon-A grand novelty. with deep apricot-yellow, long pointed buds; free-flowering and a good grower.

Liberty-Brilliant velvety crimson, of even shade throughout; perfect in every respect; excellent for outdoor and forcing.

Marechal Neil-Deep golden yellow; flowers very large and full, beautifully formed and extremely fragrant.

\section{HYBIRD TEA ROSES}

Bessie Brown - Creamy white; flowers very large and full; highly perfumed.

Betty-Flowers ruddy gold; very large, of good form and blooms constantly from June until nipped by frost; very tragrant.

Dean Hole-Silvery carmine, shaded salmon; beautiful shape.

Duchess of Albany-A rich, deep, even pink tint; free blooming and fragrant.

Etoile de France-A new French variety; flowers full and double. In color it is a rich, velvety crimson, with vivid cerise-red center.

George Dickson-Black velvety crimson, retaining its color well. Large petals of good substance, lasting well.

Gruss an Teplitz-One of the brightest colored Roses grown. Dark rich crimson, changing to bright scarlet, shading to velvet Delightfully fragrant.
Maman Cochet-Color deep rose-pink, inner side of petals silvery-rose; borne on long, stiff stems; very double and exquisite when in bud.

Mme. Abel Chatenay-Rosy carmine tinted salınon; flowers large; very free-flowering.

Mme. Jules Grolez-Bright china rose; flowers large and beautifully formed; very floriferous; fine for massing and forcing.

Mme. Ravery-Orange-yellow; large and well formed; very hardy.

Mrs. Aaron Ward-A very handsome and free-flowering variety. The color is a distinct Indian yellow, and, as the flowers expand, they shade lighter to the edges.

Ophelia-Very long bud; delicate rose, heavily flushed but opening to a beautiful salmon-flesh, shaded with rose; flowers borne on strong stems. White Maman Cochet-Iden-
fiery red. tical with Maman Cochet, except in color; an ideal bedding variety. 


\section{CLIMBING ROSES}

These are all hardy, vigorous growers, and bloom freely in June.

American Pillar-One of the Polyantha roses. A fine shade of pink with clear white eye. Very large flowers, produced in large clusters.

Climbing American Beauty (C)-The favorite of all roses in climbing form.

Crimson Rambler-As a climbing or running rose it has no equal. The foliage is rich, dark green, the growth rapid and diverse, but its great beauty is when the plant is covered with a profusion of the brightest crimson partly doubled flowers which remain on a long time.

Excelsa (C)-Very double; crimson maroon; flowers in large trusses.

Dorothy Perkins-A splendid new, shellpink Climbing Rose. The flowers are borne in clusters of 30 to 40 and sometimes even 50 to 60 . The flowers are large, very double, sweetly scented and of a beautiful shell pink. Hardy.

Flower of Fairfield-A sport from the notable Crimson Rambler, which it resembles in every respect, except that it continues to bloom all summer, producing a marvelous succession of brilliant crimson clusters from Spring till late Autumn. A rose of great value.

Lady Gay-The flowers are of a delicate cherry-pink color, which fade to a soft white.

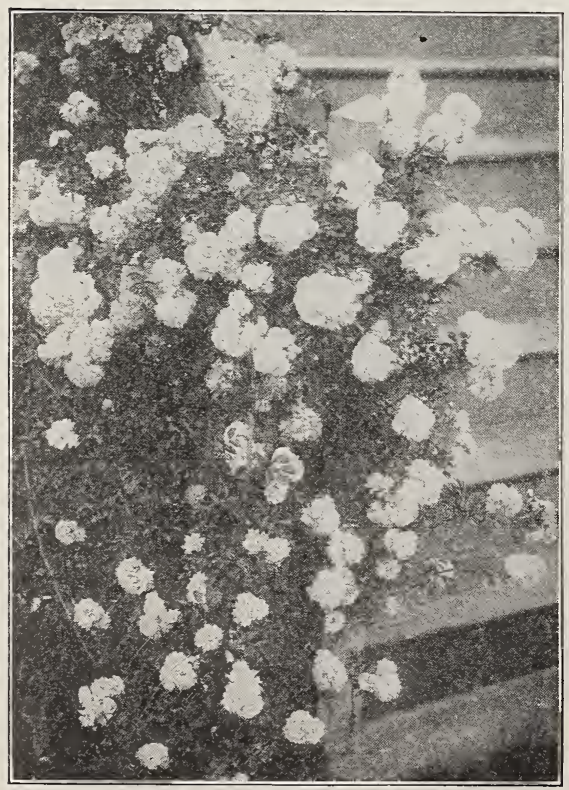

DOROTHY PERKINS

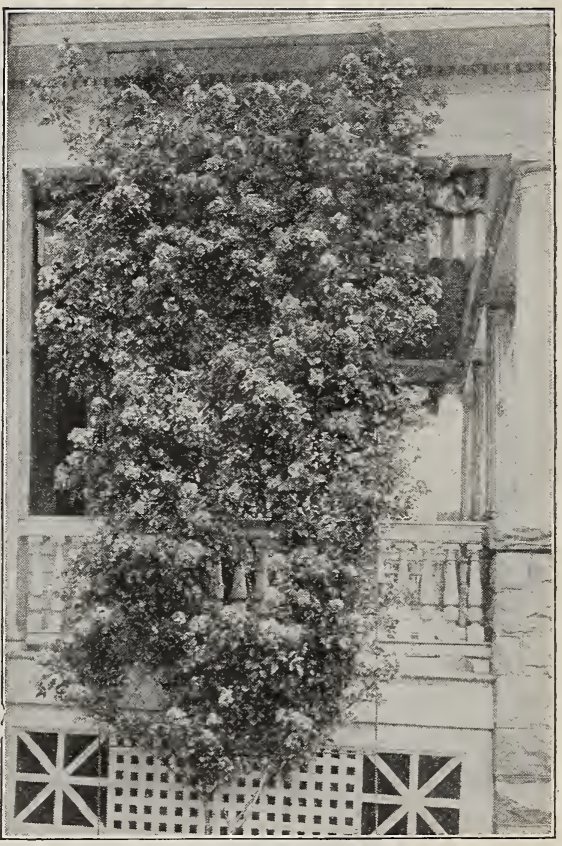

CRIMSON RAMBLER

The effect of a plant in full bloom, with the combination of the soft white flowers, the cherry-pink buds, and the deep green foliage, is indeed most charming.

Philadelphia Rambler-Improvement on the Crimson Rambler, flowers being larger, much more double and of a lighter crimson color.

Pink Rambler (Euphrosyne)-Possesses the same valuable features found in the White Rambler, with which it differs only in color of flower, which is a brilliant light carmine.

Queen of the Prairie-Bright rose color; large, compact, and globular; a very profuse bloomer. One of the best.

Tausendschon, or Thousand Beauty-The flowers are the most delicate shade of pink ever seen in a Rose, might be described as a white delicately flushed pink changing to rosycarmine. It gets its name from its many flowers and the variation in colorings.

White Rambler (Thalia)-Flowers are the size of a silver quarter, perfectly filled, very fragrant. Color pure white, sometimes tinged with blush. Blooms in clusters.

Yellow Rambler (Aglaia)-A new climbing rose of the class and habit of the famous crimson rambler; flowers medium size, cup shape, nearly full, sweet scented; blooms in large clusters; color very light yellow. 


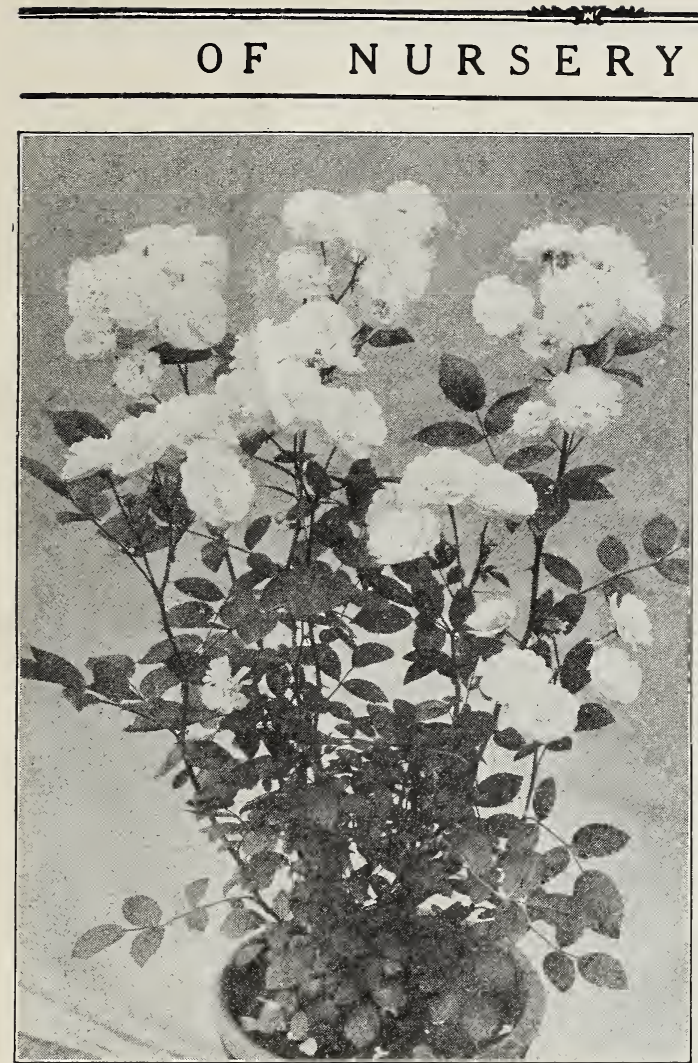

THE WHITE BABY RAMBLER

\section{MOSS ROSES}

Blanche Moreau-Pure white, large; form very perfect; flowers in clusters, heavily massed. A rampant grower.

Crested Moss-Deep pink colored buds, surrounded with a mossy fringe and crest. A fragrant, very beautiful Rose.

Perpetual, White-White flowers growing in clusters; mossy.

Pink, Moss-Free bloomer. Pale rose, very beautiful buds; a great favorite.

\section{RUGOSA ROSES AND HYBRIDS}

For massing or hedge planting, the Rugosa cannot be excelled. The hybrids are attractive in the garden.

Rosa Rugosa-An upright shrub, attaining 5 to 6 feet in height. Foliage shining dark green, deeply plicated; flowers single, red, fragrant and produced freely from June to December; fruit bright crimson-scarlet.

Alba-The habit and foliage is similar to the above, but the flowers are pure white, single and as attractive in the bud as when open; quite fragrant.

Conradi, Ferdinand MeyerThis variety is a strong, robust grower; with stout stems. The flower is clear silvery rose, very large and double; delightfully fragrant.

Mme. George Bruant-This is a very free-blooming, white variety; a strong grower and blooms continuously; flowers semi-double.

\section{DWARF BEDDING ROSES OR BABY RAMBLERS}

A type of Rose which is becom. ing very popular for bedding purposes. They form shapely, compact, bushy specimens, about 18 inches high, producing in great profusion from early in the season until severe frost, immense trusses of small flowers.

Crimson Baby Rambler (Mme. Norbet Levasseur)-Crimson flowers similar to the popular Climbing Crimson Rambler.

Pink Baby Rambler (Anchen Muller)-Brilliant, luminous pink; a shade that is always admired.

White Baby Rambler (Katheria Zeimet)-Pure white flowers, show ing the yellow stamens very prettily, produced in large candelabrashaped trusses.

\section{WICHURIANA AND ITS HYBRIDS}

Rosa Wichuriana (Memorial Rose)-A beautiful creeping species. It grows very fast, and has small, dark, shining leaves that soon cover the ground thickly. The flowers are small, white, single and fragrant.

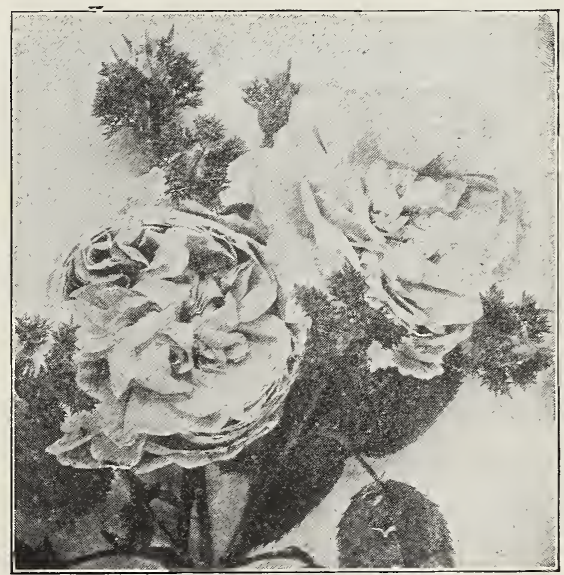

CRESTED MOSS 


\section{GENERAL CA T A L O}

\section{TRANSPLANTING TREES AND SHRUBS}

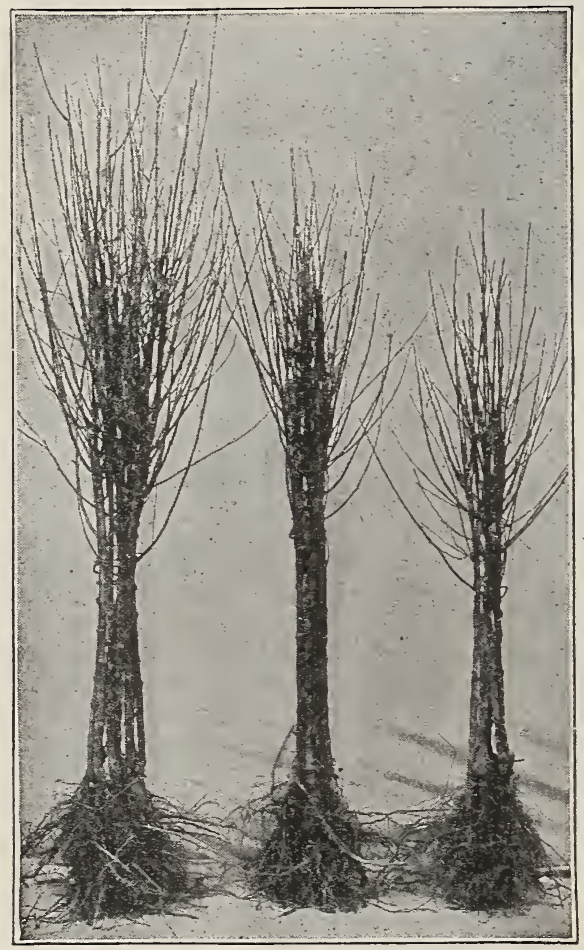

TREES AS THEY ARE RECEIVED FROM THE NURSERY.

Preparing the Trees.-In removing the tree in the nursery row, no matter how carefully the work is done a portion of the roots are broken and the balance that existed in the tree is destroyed. To make up for this, remove the broken or mutilated portions so as to leave the ends round and smooth. Never plant a tree exactly as it is received from the nursery until it has been thoroughly examined and the necessary pruning done. Proper pruning is determined by the size, form and condition of the tree.

Standard Orchard Trees. - These trees when they leave the nursery vary from five to seven feet in height. The branches that form the head should be cut back to within three or four buds of the base. Prune the roots also as directed above. With older trees, of extra size, shorten all the previous year's growth to within three or four buds of their base; also cut away the unnecessary branches if they are numerous.

Dwarf Trees.-Trees of two or three years' growth and having a number of side branches should be pruned with an eye to the growth and the form desired. Cut the branches into the form of a pyramid by shortening the lower ones about one-half, those in the middle still shorter and the uppermost ones to within three or four buds of their base. The leader should be cut back about one-half. Closer pruning is needed on trees that have been dried or injured by exposure.

Yearling Trees Intended for Pyramids.-Cut away the smallest side branches if there are any, keeping the strongest and best placed. Those having no side branches should be cut back far enough to assure the production of branches within a foot of the ground. A strong yearling about four to six feet in height may be cut back about half, weaker ones more than that. Cut too low rather than not low enough.

Preparing the Soil.-Fruit trees flourish best in a naturally dry soil; too much moisture retards growth. Plow at least twice, following the common plow the second time with the subsoil plow. Fresh lands will not need manure or fcrtilizers but lands exhausted through constant cropping should be fertilized either by turning under clover or well decomposed manure or compost. Land that is in good condition for wheat, corn or potatoes will be well adapted to fruit trees.

Planting.-Dig the hole larger than is necessary to admit all the roots in their natural position, keeping the surface soil and subsoil separate. Have the tree held in an upright position while the earth is shovelled in, the best soil being sifted in among the roots. Make sure that all the roots come in contact with the soil. When the earth is nearly filled in, pour in water to wash the soil around the roots; then fill up the remainder and tread down gently with the foot. It is only necessary to use water in dry weather.

Don't plant too deep; the trees should stand about the way they did in the nursery. Trees on dwarf stock should be planted so that all the stock is below the ground, only the graft appearing above the surface.

Staking.-Extra tall trees or those much exposed to the wind should be supported by a stake. Take care that no chafing of the tender bark occurs.

Mulching.-After the tree is set, cover the ground within a radius of two to three feet with five or six inches of manure or litter. This mulching is necessary in dry ground and is good practice in spring and fall planting.

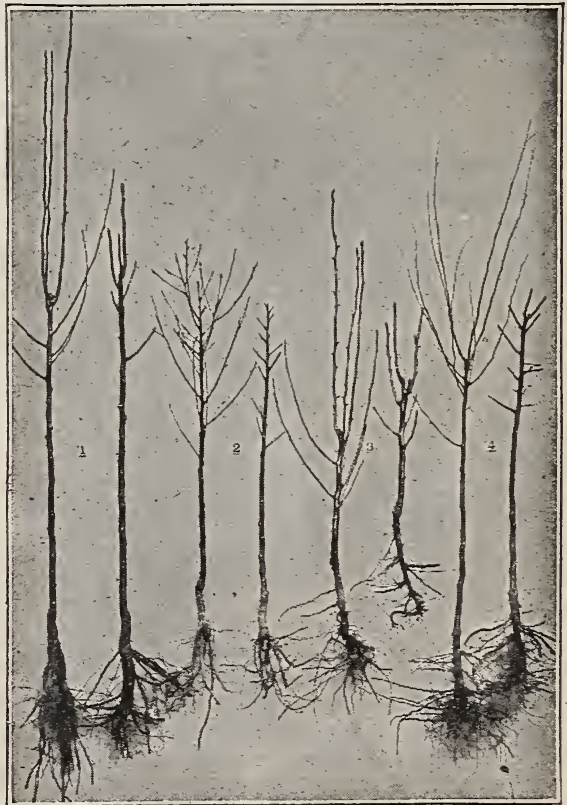

PAIRS OF TREES SHOWING THEM AS RECEIVED FROM THE NURSERY AND AFTER BEING PRLNED FOR PLANTING. I KLEFFER PEAR; 2 PEACH; 3 DWARF DUCHESS; 4 QUINCE. 


\section{OF N U R S E R Y S T O C K}

Pruning.-All fruit trees requi,e more oi less pruning from year to year. While the tree is young the head should be formed, and unnecessary branches taken out. The best time to prune is late in the winter or in early spring, when no more severe weather is anticipated.

Carrying Stock through the Winter. - The practice of procuring supplies of trees in the fall is becoming more and more general. It is a more favorable time than spring, because the stock has just entered into dormant condition. Even when fall planting is not desirable by reason of severity of the climate, the stock may be procured in the fall, and thus be on hand ready for the opportune moment in the spring.

To insure success you have only to get the trees before freezing. weather, and bury them in the following manner: Choose a dry spot where no water will stand during the winter, with no grass near it to invite mice. Dig a trench, throwing out enough dirt to admit one layer of roots below the surface, and place the trees in it, inclined at an angle of forty-five degrees or more. Widen the trench, throwing the soil among the roots in position, place another layer in the trench, reclining the tops on the others, and so on until all are in the trench. then finish by throwing up more soil until the tips of the trees are nearly or quite covered. It is also well to bank up the earth around the sides to insure more thorough protection. The exposed tops should then be covered with pine boughs, which insures them against any possibility of injury. Care should be taken to fill solid all the interstices among the roots. Too much care in doing this cannot be insisted upon, as every root which is not in close contact with the soil is sure to be killed. In the spring the trees will be on hand for transplanting at the earliest moment possible to do the work.

Care of Stock Injured by Frost or Long Exposure.-Place the unopened packages in a cellar or any cool place that is free from frost. Leave them there until the stock is thawed out. It can then be unpacked and planted or "heeled in."

If dried out from long exposure, bury in the ground, or soak in water from 12 to 24 hours. Prune such stock more closely than ordinarily.

\section{SPRAYING}

Once a plant is attacked by disease it cannot be cured in the same sense that an animal can be. Spraying aims not to cure diseased plants but to protect them from two classes of enemies, insects and fungus (fungi, plural). The purpose of spraying is then to render plants immune against the insects or fungi to be feared. The spray mixture must be injurious to the enemies it is designed to forestall.

There are three main considerations in spraying: An effective spraying machine, one adapted to the cliaracter of the work; a mixture that will defeat the enemy; and a knowledge of the proper time to spray. The first can be secured.through the manufacturers whose advertisements appear in fruit-growing magazines, the other two are explained in detail in the following paragraphs.

The principle underlying spraying is to cover the foliage or wood of plants with a medium in which the fungus will not grow, in the case of the plant parasite, or one which will poison the leaf-eating insect or kill the sucking insect by destroying its body. Both diseases and destructive insects work rapidly and a delay of a few days may make the remedy ineffective. Of all factors making for success in spraying promptness is the most important.

We advise careful attention to these five points: (I) Know the enemy you are attacking; (2) study the remedy, its principles-how it acts; (3) secure the proper appliance for using the remedy; (4) prepare the spray mixture carefully; (5) apply it thoroughly.

\section{AMMONIACAL COPPER CARBONATE}

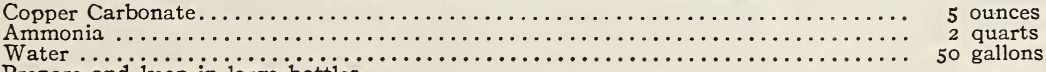

Prepare and keep in large bottles.

ARSENITE OF LEAD

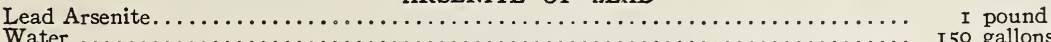

ARSENITE OF LIME

This is much cheaper than Paris Green and equally efficient. It will not burn the tenderest foliage. Formula (for 800 gallons)

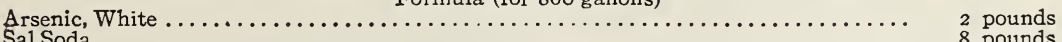

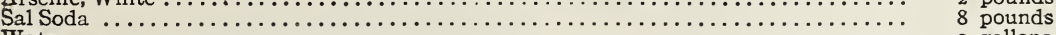

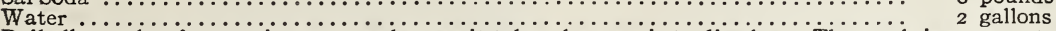

Boil all together for $\mathrm{r} 5$ minutes or as long as it takes the arsenic to dissolve. The result is a concentrated sorution that can be diluted as needed. One pint together with 2 pounds of lime added to a barrel of water makes an insecticide as good as Paris Green.

\section{BORDEAUX MIXTURE}

(Standard formula)

Copper sulphate (Blue Vitriol)

(Standard formula)

Water

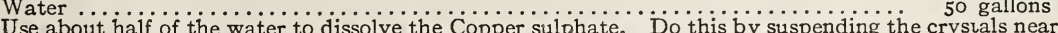
surfor in a fof to time until the lime is thoroughly slaked. Then add the remainder of the fifty gallons (about 25 will have been used for the copper sulphate, I or 2 for slaking the lime; use the remainder- 23 or 24 gallons-for diluting lime).

Have a large vessel capable of holding fifty gallons and into this pour at the same time, the lime solution and the copper sulphate solution. The spray tank or barrel may be used for this purpose. The best mixture is made by straining the solutions as they are poired. This can be done either with a coarse cloth or finemeshed wire screen.

\section{COPPER SULPHATE SOLUTION}

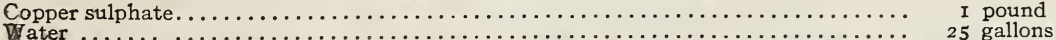

Since this is injurious to foliage it should only be used before the foliage appears. germicide and disinfectant.

\section{HELLEBORE}

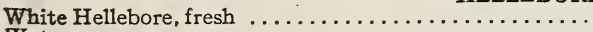

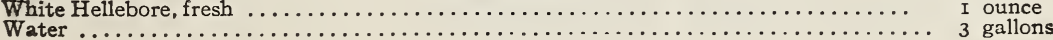




\section{KEROSENE EMULSION}

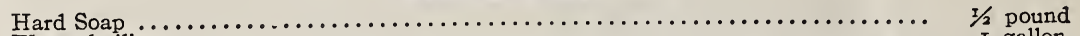

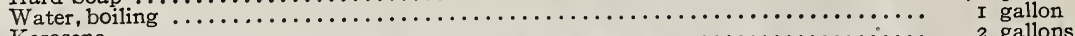

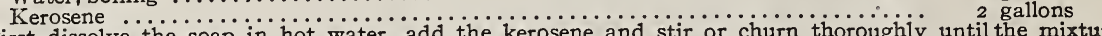
First dissolve the soap in hot water, add the kerosene and stir or churn thoroughiy until the mixture
becomes white and creamy. Dilute this solution four times for San Jose; twenty times for Aphis.

\section{LIME-SULPHUR}

The lime-sulphur solution seems destined to take the place?of the Bordeaux mixture and many other opper sprays that have been in use a long time.

(For the best information about Lime-Sulphur send for Penn. Expt. Sta. Bulletin 92, July rgog; or their atest bulletin on the subjest.)

Lime, fresh . . . . . . . . . . .

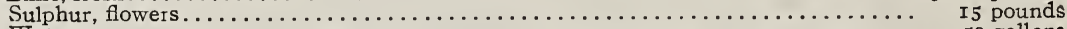

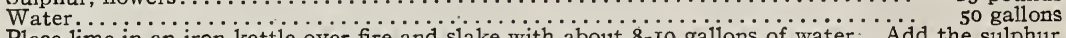

Place lime in an iron kettle over fire and slake with about 8 -1o gallons of water. Add the sulphur and salt then thoroughly. Boil the mixture for from forty to sixty minutes and stir constantly. Do not add any more water than is needed to keep the mixture from sticking and burning. Strain the mixture and add enough hot water to make 50 gallons. Always apply hot! After the mixture has been allowed to cool, crystals form which can "only be dissolved by heating.

Before using Lime-Sulphur we advise a thorough understanding of it. This can be obtained from the bulletins of numerous Experiment Stations and from fruit-growing magazines.

\section{PARIS GREEN SOLUTION}

Mix I pound of Paris Green in 200 gallons of water; stir well and keep well stirred while it is being applied.

\section{SOLUBLE OILS}

These require only the addition of water before applying. Use only those recommended by good authority. They take the place of Lime-Sulphur and have not its disadvantages.

\section{TOBACCO SOLUTIONS}

These can be prepared by boiling tobacco stems in water, two gallons to each pound of stems. Good for sucking insects.

Commercial solutions can be obtained. Use according to directions accompanying them.

\section{GRAFTING WAX}

A good grafting wax is made as follows: Resin, 4 parts; Bees' Wax, 2 parts; Tallow, I part. All by weight. This material should be carefully melted together, mixed, and when hot, poured into a pail of cold water. As soon as it is hard enough to handle, the lump should be pulled until it becomes light colored. In doing this the hands should be greased, care being taken not to use too much grease. When first taken from the water, the mixture will be a spongy mass. Unless the resin is thoroughly melted, the wax will be lumpy.

\section{GOVERNMENT PUBLICATIONS}

Write the "Superintendent of Documents, Washington, D. C." for a list of the publications issued by the rovernment. The prices and directions for securing any of the publications listed are given therein.

\section{COLLEGE AND EXPERIMENT STATION LITERATURE}

Write the Mailing Clerk or Extension Department of any agricultural college for their bulletin on the subject desired and it will be sent, if still in print. The same holds true of Experiment Stations which are of teh in connection with the colleges.

\section{TABLE OF DISTANCES FOR PLANTING TREES}

Apples. Standard, 30 to 40 feet each way.

Apples. Dwarf, I 5 ft. each way.

pears. Standard, 20 to $25 \mathrm{ft}$. each way.

Pears. Dwarf, I $5 \mathrm{ft}$. each way.

Cherries. I 8 to $20 \mathrm{ft}$. each way.

Plums. I6 to I $8 \mathrm{ft}$. each way.

Peaches. I6 to I $8 \mathrm{ft}$. each way.

Apricots. 16 to $18 \mathrm{ft}$. each way.
Nectarines. I6 to I $8 \mathrm{ft}$. each way.

Quinces. I2 $\mathrm{ft}$. each way.

Currants. 3 to $4 \mathrm{ft}$. each way.

Gooseberries. 3 to $4 \mathrm{ft}$. each way.

Raspberries. 3 to $4 \mathrm{ft}$. each way.

Blackberries. 6 to $8 \mathrm{ft}$. each way.

Strawberries. I I $/ 2 \mathrm{ft}$. to $3 \mathrm{ft}$. each way.

Grapes. 8 to Io $\mathrm{ft}$. each way.

\section{NUMBER OF TREES OR PLANTS FOR AN ACRE OF GROUND, SET AT REGULAR DISTANCES APART}

Distance Apart. No. of Plants

f inches by 3 inches ... 696,960

4 inches by 4 inches ... 392,040

( inches by 4 inches ... 174,240

9 inches by 9 inches ... 77,440

1 foot by 1 foot...... 43,560

$11 / 2$ feet by $11 / 2$ feet..... 15,370

2 feet by 1 foot....... 21,780

2 feet by 2 feet......... 10,860

$21 / 2$ feet by $21 / 4$ feet.... 6,920

3 feet by 1 foot...... 14,520

3 feet by 2 feet........ 7,260

3 feet by 3 feet........ 4,840

$31 / 2$ feet by $31 / 2$ feet..... 3,555

3 feet by 1 foot....... 10,899

4 feet by 2 feet........ $5,4,45$
Distance Apart. No. of Plants

4 feet by 3 feet. . . . . 3,630

4 feet by 4 feet. . . . . . . 2,722

$41 / 2$ feet by $41 / 2$ feet..... 2,151

5 feet by 1 foot....... 8,712

5 feet by 2 feet......... 4,356

5 feet by 3 feet. . . . . . . 2,904

5 feet by 4 feet. . . . . . 2,178

5 feet by 5 feet........ 1,742

$5 \mathrm{r} / 2$ feet by $5 \mathrm{r} / 2$ feet.... 1,417

6 feet by 6 feet....... 1,210

7 feet by 7 feet.......... 881

8 feet by 8 feet........... 680

10 feet by 10 feet...... 435

12 feet by 12 feet...... 302
Distance Apart. No. of Plants 13 feet by 13 feet. . . . . $\quad 257$ 14 feet by 14 feet....... 222 15 feet by 15 feet....... 193 16 feet by 16 feet....... 170 17 feet by 17 feet....... 150 18 feet by 18 feet...... $\quad 134$ 19 feet by 19 feet...... 120 25 feet by 25 feet. . . . . $\quad 69$ 30 feet by 30 feet...... 48 33 feet by 33 feet. . . . . . 40 40 feet by 40 feet...... 27 50 feet by 50 feet...... 17 60 feet by 60 feet...... 12 65 feet by 66 feet....... 10

To estimate the number of plants required for an acre at any given distance, multiply the distance between the rows by the distance between the plants, which will give the number of square feet allotted to each plant, and divide the number of square feet in an acre $(43,560)$ b: $\$$ is: number and the quotient will be the number of plants required. 


\begin{tabular}{l}
\hline WHAT TO SPRAY FOR \\
San Jose Scale, Scurfy Scale \\
Bud Moth, Eggs of Apple \\
Eggs of Red Spider [Aphis \\
Green Peach Aphis \\
Uyster Shell Scale \\
Peach Leaf Curl \\
Pear Leaf Blister Mite \\
Strawberry Leaf Blight
\end{tabular}

Thrips

\section{Apple Scab}

Black Rot of Apple

Brown Rot of Prune

Bud Moth

Caterpillars

Codling Moth

Canker (N. Y. Apple)

Mildew, apple

Scab, apple and pear

Grape Rot and Anthracnose

Plum Curculio

\section{SPRAY TO USE \\ Lime Sulfur \\ Winter strength}

Lime Sulfur

Summer strength

Nicotine Extract

(2.7 per ct.) 6 qts.

Water .... r 00 gals.

Soap ...2 to 5 lbs.

Lime sulphur

Summer strength and

Arsenate of Lead

3 lbs. to 50 gallons

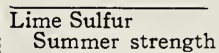

Lime Sulfur
Summer strength

Arsenate of Lead

Aphison trees \&garden crops

Leaf Hopper

Oyster Shell ${ }^{\circ}$ Bark Louse

Red Spider

Woolly Aphis on Branches

Peach Brown Rot

Peach Scab

Raspberry Cane Blight

Apple Cankers, Aphis Eggs

Pear Leaf Blister Mite

Red Spider Eggs

Tent Caterpillar Eggs

Woolly Aphis

Grape Mildew

Tussock Moth

\section{Crown Gall}

Fire Blight

Raspberry Cane Blight

Strawberry Crown and

Root Borers

Leaf Rollers

Kerosene Emulsion or Tobacco Black Leaf

\section{Lime Sulfur}

Selfboiled 8-8-50 Resin-Bordeaux

Lime Sulfur

Winter strength

Flowers of Sulfur

\section{REMARKS}

Apply while buds are swelling to Apples, Pears, Peaches, Plums and Cherries and small fruits, using the winter strength lime sulphur drenching all parts of the tree.

Test both the commercial and homemade lime sulphur with hy. drometer before using to secure the correct strength. The tree must be completely covered with winter strength lime-sulfur when spraying for scale insects. Coat every portion from ground to tip of twigs.

Apply when new leaves start. Repeat every 10-15 days until flowers appear. Burn leaves as soon as crop is harvested.

The period for effective spraying against the adult thrips, is during the time when the buds are swollen and partly open, and until they are entirely open at the tips. Spray for the larvæ after the petals drop to reduce the number of insects for the following year.

First application. Just before blossoms open, for apple scab and various leaf-eating insects, use lime-sulphur solution $\left(32^{\circ}\right.$ Beaume) diluted with 40 parts of water, with 2 to 3 pounds arsenate of lead to 40 gallons.

Second application. When blossoms are about two-thirds off, give same treatment as (2). This is the most important spraying for a ple scab and codling moth. Should never be omitted.

Third application. About two weeks later repeat (2) if weather is favorable for apple scab; that is, moist and warm.

Fourth application. About first week in August repeat (2) to prevent late infections of apple scab and to control second brood of codling moth.

\section{PEARS}

Spray as for apples. As foliage appears to be more susceptible to injuries by the spraying mixture, dilute the concentrated lime-sulphur solution $\left(32^{\circ}\right.$ B.) in the proportions of 1 to 50 and apply the liquid in minimum quantities, using nozzles with fine apertures.

See Arsenate of Lead for combination spray.

Apply when leaves are half grown; Just before blossoming; When fruit has set.

Repeat once or twice at intervals of two weeks. If latter applications are necessary use ammonical copper carbonate solution.

\section{PLUMS}

First application. When "husks" or calyces drop, spray with arsenate of lead, 3 lbs. to 50 gals. of water for the curculio. For leaf spot on European varieties use bordeaux mixtures 5-5-50 with arsenate of lead. Second application. For leaf spot repeat spraying with bordeaux mixture about ten days later.

Japanese varieties of plums should be sprayed as directed for peaches CHERRIES

Spray as for plums for San Jose scale and the curculio. PEACHES

First application. When "husks" or calyces are dropping use two pounds of arsenate of lead to fifty gallons of water for the curculio. The self-boiled lime-sulphur mixture may be used as carrier of the poison to control also brown rot and scab.

Second application. Two or three weeks later use 88-8-50 selfboiled lime-sulphur mixture and two pounds of arsenate of lead.

Third application. About one month before fruit ripens repeat treatment with self boiled mixture, omitting the poison.

These are contact insecticides and should be applied to exposed and tender bodies of young. These are all sucking insects and food poisons are of little value.

Be sure to penetrate covering of woolly aphis; be thorough, do not allow any to escape.

Spray four weeks after blossoms have fallen, again in three weeks and about one month before fruit ripens.

Apply just after leaves have fallen.

Spraying in spring before buds open may be substituted for this for combating insects and fungus pests. However, it may be desirable to apply in fall on account of rabbits.

For mildew on grape use finely pulverized sulfur. Dust ground and vines freely on a bright morning. This should not be applied while the weather is damp or the vines wet.

Band trees with tanglefoot or strips of raw cotton, binding it in the middle, leaving band loose above or below. Do not apply sticky preparations directly on bark of trees. Use bands during June, July and August. Remove egg clusters which appear in masses as a white froth.

Crown Gall is a bacterial disease of root or crown of trees. All infected trees should be destroyed. Keep a constant lookout for this trouble. Fire Blight bacteria may extend below discolored or blackened region, hence cut should be made about one foot below. Disinfect knife and wound with mercuric bichloride one part to 1000 parts of water.
Strawberry plants should be dug up and burned before May 1 to destroy insects before beetles escape to lay eggs.

For strawberry leaf roller, burn top as soon as crop is gathered. 


\section{INDEX}

Aralia ............ 17

Achillea............. 33

Aconitum............ 33

Akebia ............. 30

Adam's Needle......... 33

Althea or Rose of Sharon... 24

Almond Flg.......... 17

Apples .............. 3

Anemone ............ 33

Anthemis ............. 33

Aquilegia $\ldots \ldots \ldots \ldots \ldots . \ldots 34$

Arbor Vitæ ........... 22

Apricots.................. 11

Aristolochia .......... 30

Ash ................ 17

Asparagus .............. 14

Aster .............. 34

Azalea............. 24

Baby Rambler.......... 43

Barberry ............ 24

Beech ............ 17

Bignonia ............. 30

Birch.............. 18

Blackberries ........... 14

Box............... 24

Butterfly Bush........ 34

Calycanthus .......... 25

Campanula ........... 34

Catalpa............. 18

Celastrus ............ 30

Cherries............. 7

Cherry Flg .......... 18

Chrysanthemum........ 34

Cinnamon Vine....... 30

Clematis. . ........... 31

Clethra Alnifolia........ 25

Climbing Roses......... 42

Convallaria.......... 34

Climbing Vines.......... 30

Crab Flg............ 18

Crab Apples........... 5

Currants ............ 15

Cypress.............22

Daisy Shasta......... 34 Deciduous Ornamentals. . 17 Deciduous Shrubs ...... 24

Delphinium .......... 34

Deutzia............ 25

Dianthus ............ 35

Digitalis.. .......... 35

Dicentra.............. 35

Dogwood .......... 18, 25
Eleagnus ........... 25

Elder .............. 25

Elm ............... 18

Euonymous.......... 31

Evergreen Trees........22

Exochorda ........... 26

Forsythia $\ldots \ldots \ldots \ldots \ldots 26$

Fringe ............. 26

Funkia ........... 35

Gaillardia ........... 35

Gooseberries .......... 15

Grapes............ 12

Halesia ............. 26

Hemerocallis ......... 35

Herbaceous Perennials... 33

Hollyhock ........... 35

Honeysuckle .........26, 31

Horse Chestnut......... 19

Hybrid Perp. Roses...... 38

Hybrid Tea Roses........ 41

Hydrangea .......... 27

Hypericum .......... 26

Ilex $\ldots \ldots \ldots \ldots \ldots \ldots 27$

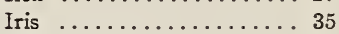

Ivy $\ldots \ldots \ldots \ldots \ldots \ldots . . .32$

Japan Quince ......... 27

Judas Tree............ 19

Juniper............ 23

Kerria ............. 27

Koelreuteria .......... 19

Laburnum ........... 19

Larch .............. 19

Lilac .............. 27

Linden or Lime....... . 19

Magnolia ............ 19

Maiden Hair Tree........ 19

Maple.............. 20

Matrimony Vine....... 32

Moss Roses........... 43

Mountain Ash.......... 20

Mulberry, Weeping. ..... 20

Myosotis ............ 35

Nuts................. 15

Oak............... 20

Oenothera ............... 36

Ornamental Trees...... 17
Paeonies............. 36

Papaver............. 36

Peach Flg............ 2n

Peaches.............. 10

Pears ............... 8

“ Dwarf......... 9

Phlox .............. 36

Pine .............. 23

Platycodon ........... 37

Plums ............. 16

Plum, Flg........... 21

Poplar ............. 20

Privet. . ........... 28

Quinces $\ldots \ldots \ldots \ldots \ldots \ldots 12$

Raspberries .......... 14

Rhodotypus .......... 28

Rhubarb ............ 14

Roses ............... 38

Rudbeckia .......... 37

Rugosa Roses and Hybrids. 43

Snowball ............ 28

Solidago ........... 37

Spirea. . . . . . . . . . 29

Spray Calendar ....... 47

Spruce .............. 23

Stephanandra ......... 29

Stokesia............ 37

Strawberries .......... 18

Strawberry or Spindle Tree. 29

Sumac ............ 29

Sycamore ........... 21

Symphoricarpus ........ 30

Syringa. . . . . . . . . . 29

Tamarix........... 30

Taxus $\ldots \ldots \ldots \ldots \ldots \ldots .23$

Thorn .............21

Transplanting Trees and Shrubs .......... 44

Tritoma........... 37

Trollius............ 37

Trumpet Vine.......... 32

Tulip Tree ..........21

Weigelia............ 30

Wichuriana ..........43

Willow............. 21

Wistaria............ 32

Yellow Wood ........21 



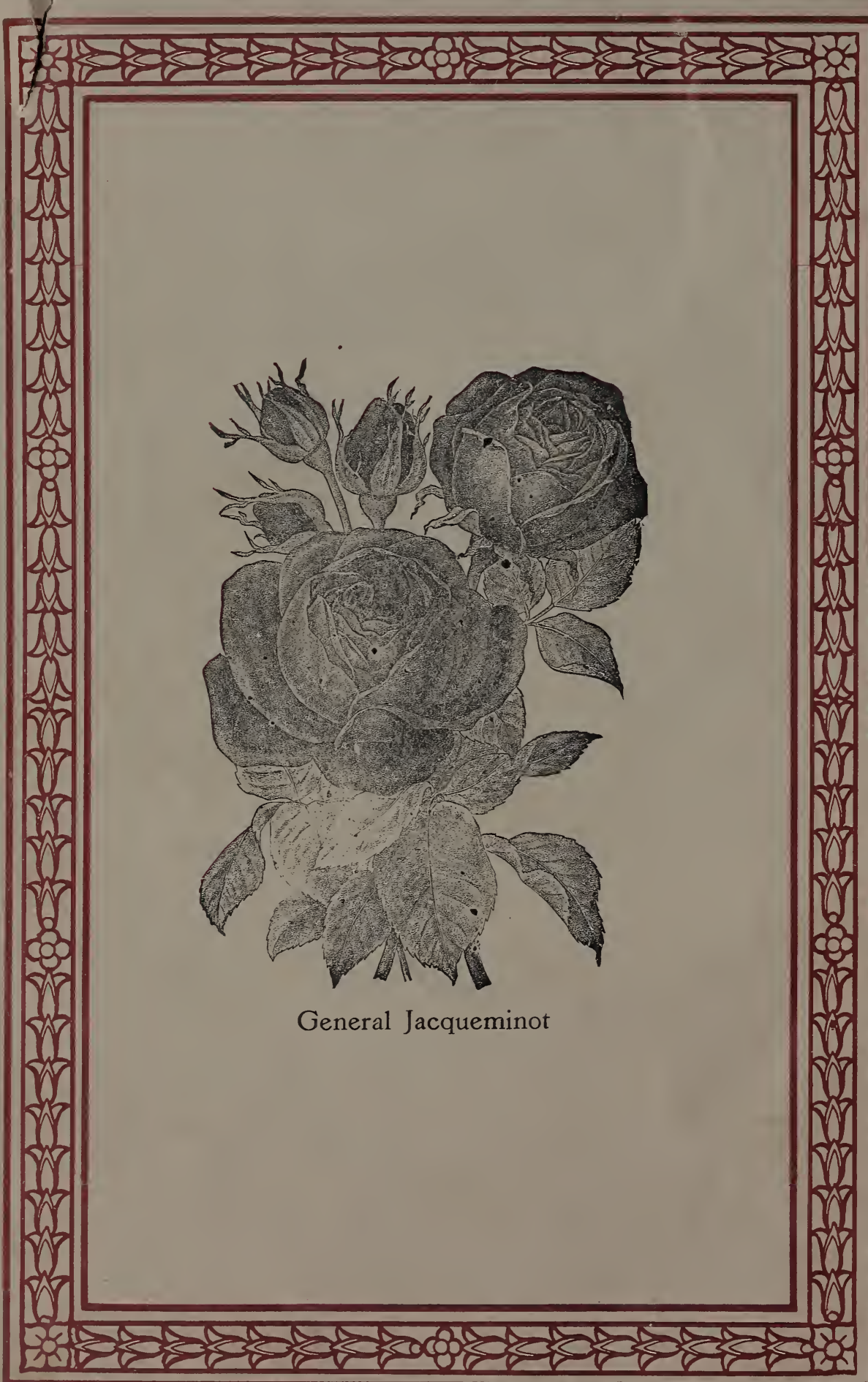

